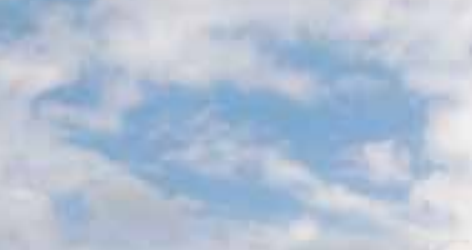

No:

10.

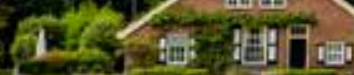

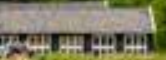

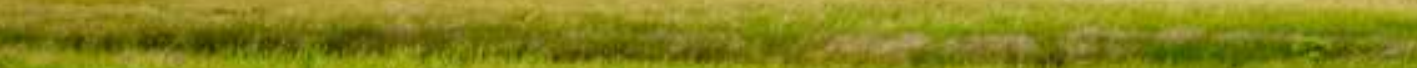

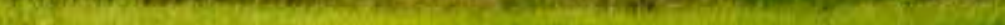

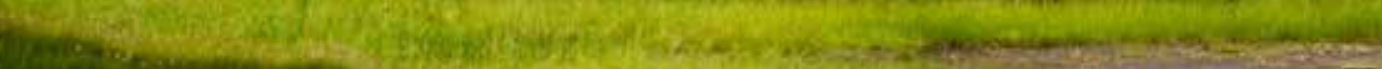

20.5.

if $x^{2}$ tate

-

aris tuase?

ching

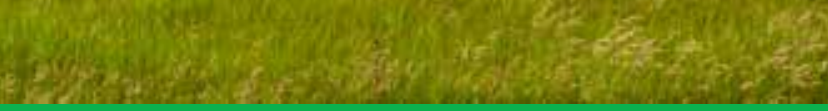

\title{
Ammonia regulations near nature areas in Denmark and the Netherlands compared
}

Harry Luesink and Rolf Michels

WAGENINGEN

UNIVERSITY \& RESEARCH 



\section{Ammonia regulations near nature areas in Denmark and the Netherlands compared}

Harry Luesink and Rolf Michels

This study was carried out by Wageningen Economic Research and was commissioned and financed by the Ministry of Environment and Food of Denmark

Wageningen Economic Research

Wageningen, April 2018

REPORT

2018-009

ISBN 978-94-6343-766-0 
Luesink, H. And R. Michels, 2018. Ammonia regulations near nature areas in Denmark and the Netherlands compared. Wageningen, Wageningen Economic Research, Report 2018-009. 68 pp.; 12 fig.; 28 tab.; 26 ref.

Bedrijven die binnen 400 m van Natura 2000-gebieden willen uitbreiden, maken extra kosten vergeleken met bedrijven die geen negatieve invloed hebben op natuurgebieden. Voor bedrijven in Denemarken zijn die kosten hoger dan in Nederland. Voor bedrijven die wat verder weg liggen van Natura 2000-gebieden (tussen 400 en $2.000 \mathrm{~m}$ ) is het juist andersom: dan worden bedrijven in Nederland geconfronteerd met hogere kosten dan in Denemarken.

Farms that want to expand within $400 \mathrm{~m}$ from Natura 2000 areas, have extra costs compared to farms with no negative influence on nature areas. These extra costs are higher for farms in Denmark than in the Netherlands. For farms further away from Natura 2000 areas $(2,000 \mathrm{~m})$ it is the other way around: then farmers in the Netherlands are confronted with higher costs than in Denmark.

Key words: Costs, Ammonia emission, Nature 2000 areas, the Netherlands, Denmark

This report can be downloaded for free at https://doi.org/10.18174/445690 or at www.wur.eu/economic-research (under Wageningen Economic Research publications).

(C) 2018 Wageningen Economic Research

P.O. Box 29703, 2502 LS The Hague, The Netherlands, T +31 (0)70 3358330 ,

E communications.ssg@wur.nl, http://www.wur.eu/economic-research. Wageningen Economic Research is part of Wageningen University \& Research.

\section{(cc) BY-NC}

For its reports, Wageningen Economic Research utilises a Creative Commons Attributions 3.0 Netherlands license.

(C) Wageningen Economic Research, part of Stichting Wageningen Research, 2018

The user may reproduce, distribute and share this work and make derivative works from it. Material by third parties which is used in the work and which are subject to intellectual property rights may not be used without prior permission from the relevant third party. The user must attribute the work by stating the name indicated by the author or licensor but may not do this in such a way as to create the impression that the author/licensor endorses the use of the work or the work of the user. The user may not use the work for commercial purposes.

Wageningen Economic Research accepts no liability for any damage resulting from the use of the results of this study or the application of the advice contained in it.

Wageningen Economic Research is ISO 9001:2008 certified.

Wageningen Economic Research Report 2018-009 | Project code 2282200328

Cover photo: Shutterstock 


\section{Contents}

$\begin{array}{ll}\text { Summary } & 5\end{array}$

S.1 Key findings $\quad 5$

S.2 Complementary findings $\quad 5$

S.3 Method 6

$\begin{array}{ll}\text { Samenvatting } & 8\end{array}$

$\begin{array}{lll}\text { S.1 Belangrijkste uitkomsten } & 8\end{array}$

S.2 Overige uitkomsten $\quad 8$

$\begin{array}{lll}\text { S.3 Methode } & 9\end{array}$

1

$\begin{array}{ll}\text { Introduction } & 11\end{array}$

1.1 Reference 11

1.2 Objective 11

$\begin{array}{ll}1.3 & \text { Approach and reading information }\end{array} 11$

Data sources and method $\quad 12$

2.1 Brief overview of agricultural production 12

2.2 Overview of ammonia-reduction measures 12

2.3 Costs of ammonia-reduction measures at farm level 12

$\begin{array}{llr}3 & \text { Brief overview of agricultural production } & 14\end{array}$

3.1 The Netherlands $\quad 14$

3.1.1 General 14

3.1.2 Export of livestock products 17

$\begin{array}{ll}3.1 .3 \text { Agriculture production near nature } & 17\end{array}$

$\begin{array}{lll}3.2 & \text { Denmark } & 20\end{array}$

3.2.1 General 20

$\begin{array}{ll}3.2 .2 \text { Export of livestock products } & 21\end{array}$

3.2.3 Agriculture production near nature $\quad 21$

$\begin{array}{lll}3.3 & \text { Comparison of the Netherlands with Denmark } & 23\end{array}$

$\begin{array}{ll}\text { Ammonia-reduction measures } & 24\end{array}$

4.1 The Netherlands $\quad 24$

4.1.1 Regular ammonia-emission regulation $\quad 24$

4.1.2 Integrated Approach to Nitrogen (PAS) 26

4.1.3 The principles of room for deposition and room for economic

4.1.4 Room for development for agriculture $\quad 28$

4.1.5 Calculations of nitrogen deposition impact 29

4.1.6 Allocation of room for deposition 29

4.1.7 Monitoring and adjustments $\quad 32$

4.1.8 Favourable conservation status and critical loads 32

4.2 Denmark 33

4.2.1 Regular ammonia-emission regulation 33

4.2.2 The allowed emissions now and in future $\quad 35$

4.2.3 Ammonia-emission regulation near nature 36

4.3 Comparison of the Netherlands with Denmark 37 
$\begin{array}{lll}5.1 & \text { The Netherlands } & 40\end{array}$

5.1.1 General $\quad 40$

$\begin{array}{ll}5.1 .2 \text { Finishers } & 40\end{array}$

$\begin{array}{ll}5.1 .3 \text { Dairy cows } & 42\end{array}$

5.1.4 Broilers $\quad 43$

$\begin{array}{lll}5.2 & \text { Denmark } & 45\end{array}$

5.2.1 General $\quad 45$

$\begin{array}{ll}5.2 .2 \text { Finishers } & 46\end{array}$

$\begin{array}{ll}5.2 .3 \text { Dairy cows } & 49\end{array}$

5.2.4 Broilers 50

5.2.5 Summery for the case farms

5.3 Comparison of the Netherlands with Denmark $\quad 52$

$\begin{array}{llr}6 & \text { Discussion } & 53\end{array}$

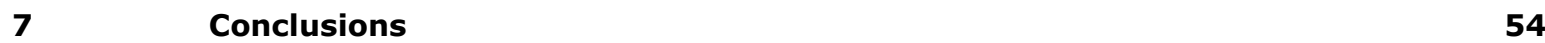

$\begin{array}{ll}\text { References and websites } & 56\end{array}$

Appendix 1 Characteristics of the cases and the case farms before $\begin{array}{ll}\text { expanding } & 58\end{array}$

$\begin{array}{lll}\text { Appendix } 2 & \text { Overview Dutch agriculture near nature } & 59\end{array}$

Appendix 3 Emission factors from Dutch Regeling Ammoniak en Veehouderij (RAV)

Appendix 4a An overview of the rules regarding the emission of ammonia in Denmark before 1 August 2017 


\section{Summary}

\section{S.1 Key findings}

Farms expanding within $\mathbf{4 0 0}$ m from Natura 2000 areas, have extra costs compared to farms with no negative influence on nature areas. These extra costs are higher for farmers in Denmark than in the Netherlands. For farms further away from Natura 2000 areas $(2,000 \mathrm{~m})$ it is the other way around: then farmers in the Netherlands are confronted with higher costs than in Denmark.

The extra costs that farmers who are located near nature areas have to make when expanding are strongly related to the rules that apply. In Denmark, the rules for farms located within $400 \mathrm{~m}$ of Natura 2000 areas are stricter than in the Netherlands, and as a result the extra costs when expanding the farm are also higher. In both countries the extra costs are housing costs due the situation that farmers close to nature areas had to build stables which reduce the ammonia emission further than farmers who have no influence on nitrogen deposition on nature. For the finisher case farm with more than one neighbour, the extra costs in Denmark are about $€ 32,000$ per farm and in the Netherlands when no room for development is available $€ 20,500$ (Table S.1).

When a farm is located between a distance of 400 and 2,000 $\mathrm{m}$ from a Natura 2000 area, the rules in the Netherlands are stricter and the extra costs are higher (Table S.1). So if the finisher case farm is located 2,000 $\mathrm{m}$ from a Natura 2000 area and the extra deposition is more than $0.014 \mathrm{~kg}$ of nitrogen per ha per year at the Natura 2000 area, then there are no extra costs in Denmark, whereas in the Netherlands the extra costs are $€ 20,500$ when no room for development is available. For dairy and broiler farms, the situation between both countries is quite similar.

Table S.1 Extra year costs $(€)$ per farm for the case finisher, dairy and broiler farm in the vicinity of nature areas in Denmark and the Netherlands for different situations when expanding by $100 \%$

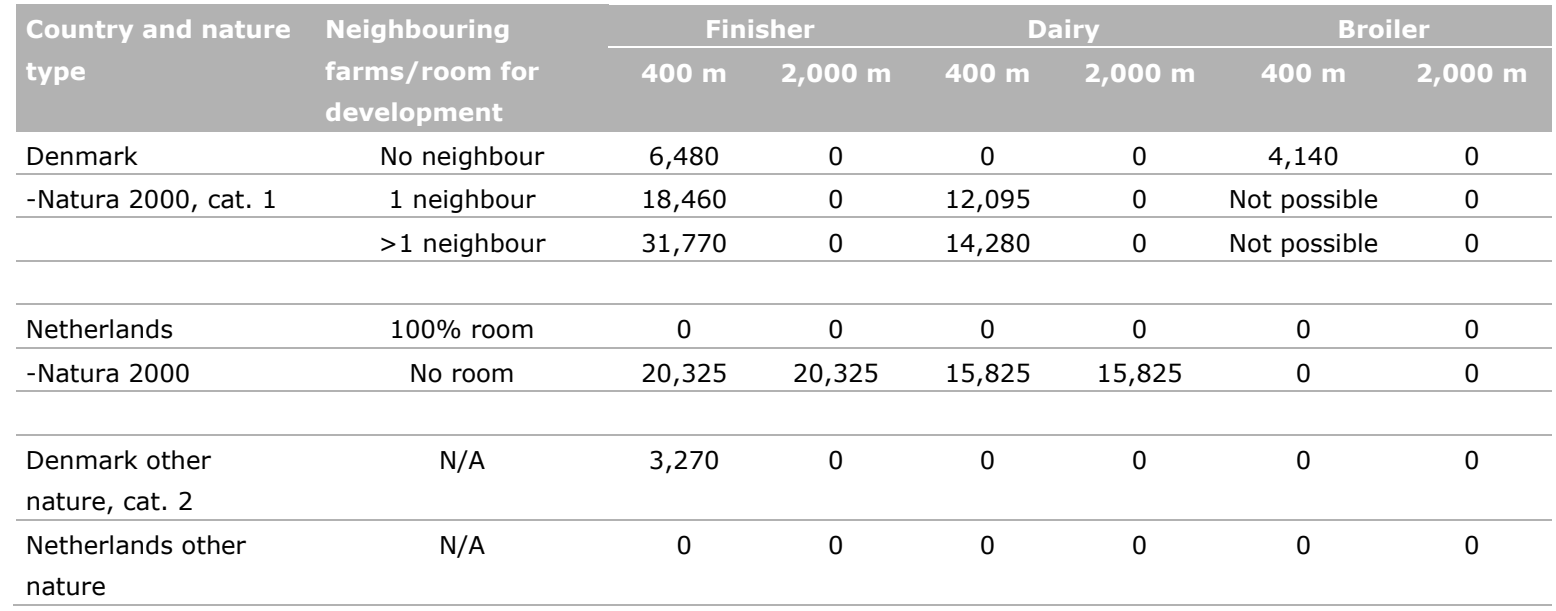

\section{S.2 Complementary findings}

The ammonia-emission regulations around nature areas are very different in Denmark and the Netherlands. In the Netherlands, the rules apply to extra emission, and it is always possible to emit the same amount of ammonia as before expanding. In Denmark, the rules are stricter in case of expansion in that a farm that is located close to a Natura 2000 area ( $<400 \mathrm{~m}$ ) must have a lower emission than before expanding (this applies to the whole farm). 
When a farm is located at 2,000 m from Natura 2000 areas, a farm in Denmark has to take no extra measures when expanding. In the Netherlands, the type of measures a farm has to take does not necessarily depend on the distance from a Natura 2000 area. It all boils down to whether the expanding farm will cause too much extra nitrogen deposition in nitrogen-sensitive nature areas. When the extra deposition is more than $1 \mathrm{~mol}$ or $0.014 \mathrm{~kg}$ of nitrogen deposition per ha, the farm has to take extra measures. In principle, a farm can obtain so-called room for development (if available), which means that the farm gets a permit for a deposition of more than $1 \mathrm{~mol}$ or $0.014 \mathrm{~kg}$ of nitrogen per ha. The local government decides about how much room for development will be available (generally, the maximum deposition is $3 \mathrm{~mol}$ or $0.042 \mathrm{~kg}$ of nitrogen per ha). In Denmark, the amount of ammonia a farm may emit after expanding depends on the number of neighbouring husbandry farms; this is not the case in the Netherlands. In Denmark, it is not possible for broiler farms close to Natura 2000 areas to expand by $100 \%$ if there are neighbouring husbandry farms, because the ammonia emissions must be lower than the technologies that are in the list of the Environmental Protection Agency of Denmark allow for.

The regular ammonia-emission regulations for storage of manure and for application of manure in the Netherlands are stricter than in Denmark. When it comes to housing systems, it is the other way around. The rules for new build housing systems for finishers and dairy are often stricter in Denmark:

- A pig farm with finishers may emit in $20181.24 \mathrm{~kg}$ of $\mathrm{NH}_{3}-\mathrm{N}$ per animal place in the Netherlands and $1.06 \mathrm{~kg}$ of $\mathrm{NH}_{3}-\mathrm{N}$ in Denmark (farm size: 75-250 LSU). Because a finisher in Denmark has other start and end weights than in the Netherlands, the maximum emission per square meter is $1.62 \mathrm{~kg}$ of $\mathrm{NH}_{3}-\mathrm{N}$ in Denmark and $1.46 \mathrm{~kg}$ in the Netherlands. Expressed in square metres, the Netherlands is then the strictest country but expressed in animal places, Denmark is the strictest.

- A dairy farm in the Netherlands may emit in $20187.1 \mathrm{~kg} \mathrm{NH}-\mathrm{N}$ per animal place and in Denmark $5.35 \mathrm{~kg}$ (farm size > 75 LSU).

- A broiler farm in the Netherlands may emit in $20180.029 \mathrm{~kg} \mathrm{NH}-\mathrm{N}$ per animal place and in Denmark $0.031 \mathrm{~kg}$ (farm size >75 LSU).

\section{S.3 Method}

The Ministry of Environment and Food of Denmark requested Wageningen Economic Research to determine the impacts of measures to control ammonia emissions on animal production systems near nature areas in the Netherlands and in Denmark. In more detail, the objective of the study is:

1. to gain insight into the measures that animal farms that are located near nature areas have to take with respect to reducing ammonia emissions when they expand their animal production, both in the Netherlands and Denmark.

2. to assess the costs related to these measures in both countries.

3. to compare the Dutch and Danish situation.

For the analysis, statistic data concerning the agricultural production, the ammonia-reduction measures and the cost of ammonia-reduction measures have been collected. For the Dutch situation, this is done by Wageningen Economic Research and Wageningen Livestock Research. For the Danish situation, these data are collected and described by the University of Copenhagen (Jacobson and Ståhl; version 17 October 2017). Wageningen Economic Research compared the information of both countries and drew conclusions.

The study starts with a brief overview of agricultural production. In the Netherlands, this is based on the National Agriculture Census (CBS, 2017) and in Denmark on data from Statistics Denmark (2016). The data on the national ammonia-emission regulations in the Netherlands and Denmark are briefly described. 
The extra ammonia regulations for farms located near Natura 2000 and other nature areas have been analysed in detail. The costs of the ammonia-reducing measures that a farm has to take in case of expansion of their livestock farm in the proximity of Natura 2000 areas, are calculated for three case farms chosen by the Ministry of Environment and Food of Denmark (Appendix 1):

1. A farm with 7,200 finishers annually that is expanding to 14.400 finishers.

2. A farm with 120 dairy cows annually expanding to 240 dairy cows.

3. A farm with 300,000 broilers annually expanding to 600,000 broilers. 


\section{Samenvatting}

\section{S.1 Belangrijkste uitkomsten}

De extra kosten voor bedrijfsuitbreiding nabij Natura 2000 -gebieden ( $<400 \mathrm{~m}$ ) zijn voor agrarische bedrijven in Denemarken hoger dan in Nederland, vergeleken met bedrijven die geen negatieve invloed hebben op natuurgebieden. De extra kosten zijn uitsluitend huisvestingskosten. Voor bedrijven die 400 tot 2.000 m van Natura 2000 -gebieden liggen, is het juist andersom: dan worden de bedrijven in Nederland geconfronteerd met hogere kosten dan in Denemarken.

De extra kosten die bedrijven dienen te maken bij uitbreiding wanneer ze bij natuurgebieden liggen heeft een sterke relatie met de geldende regelgeving. In Denemarken zijn de regels voor bedrijven die dicht bij Natura 2000-gebieden gevestigd zijn strenger dan in Nederland, daardoor zijn de extra kosten bij uitbreiding van het bedrijf ook hoger. Die extra kosten worden in beide landen veroorzaakt doordat veehouders bij uitbreiding bij natuurgebieden stallen dienen te bouwen met verdergaande ammoniakreductie maatregelen dan andere veehouders die geen extra depositie op natuurgebieden veroorzaken. Voor het vleesvarkens voorbeeld bedrijf met meer dan 1 veehouderij bedrijf als buur zijn de extra kosten in Denemarken ongeveer $€ 32.000$ per bedrijf en in Nederland wanneer geen ontwikkelingsruimte beschikbaar is $€ 20.500$ (tabel S.1).

Wanneer een bedrijf tussen de 400 en 2.000 m van een Natura 2000-gebied is gevestigd, dan zijn de regels in Nederland strenger en de kosten hoger (tabel S.1). Wanneer het voorbeeld vleesvarkensbedrijf $2.000 \mathrm{~m}$ van een Natura 2000-gebied is gevestigd en de extra depositie is meer dan 0,014 kg stikstof per ha per jaar op het natura 2000-gebied, dan zijn er in Denemarken geen extra kosten, maar in Nederland zijn de extra kosten $€ 20.500$ wanneer er geen ontwikkelingsruimte beschikbaar is. Voor melkvee en vleeskuikenbedrijven zijn de situaties in beide landen vergelijkbaar met elkaar.

Tabel S.1 Extra jaar kosten (€) per bedrijf voor het voorbeeld vleesvarken-, melkvee- en vleeskuikenbedrijf in de nabijheid van natuurgebieden in Nederland en Denemarken voor verschillende situaties wanneer ze met $100 \%$ willen uitbreiden

\begin{tabular}{|c|c|c|c|c|c|c|c|}
\hline \multirow[t]{2}{*}{ Land en natuur type } & \multirow{2}{*}{$\begin{array}{l}\text { Naburige bedrijven/ } \\
\text { ontwikkelingsruimte }\end{array}$} & \multicolumn{2}{|c|}{ Vleesvarken } & \multicolumn{2}{|c|}{ Melkvee } & \multicolumn{2}{|c|}{ Vleeskuiken } \\
\hline & & $400 \mathrm{~m}$ & $2.000 \mathrm{~m}$ & $400 \mathrm{~m}$ & $2.000 \mathrm{~m}$ & $400 \mathrm{~m}$ & $2.000 \mathrm{~m}$ \\
\hline Denemarken & Geen buren & 6.480 & 0 & 0 & 0 & 4.140 & 0 \\
\hline Natura 2000 , cat. 1 & $>1$ buur & 31.770 & 0 & 14.280 & 0 & Niet mogelijk & 0 \\
\hline Nederland & $100 \%$ ruimte & 0 & 0 & 0 & 0 & 0 & 0 \\
\hline $\begin{array}{l}\text { Denemarken andere } \\
\text { natuur, cat. } 2\end{array}$ & n.v.t. & 3.270 & 0 & 0 & 0 & 0 & 0 \\
\hline $\begin{array}{l}\text { Nederland andere } \\
\text { natuur }\end{array}$ & n.v.t. & 0 & 0 & 0 & 0 & 0 & 0 \\
\hline
\end{tabular}

\section{S.2 Overige uitkomsten}

De regelgeving van ammoniakemissie rond natuurgebieden verschilt flink tussen Denemarken en Nederland. In Nederland is de regelgeving gericht op de extra ammoniakemissie en is het altijd mogelijk om na uitbreiding dezelfde hoeveelheid ammoniak te emitteren. In Denemarken is de 
regelgeving bij uitbreiding strenger wanneer een bedrijf binnen $400 \mathrm{~m}$ van een Natura 2000-gebied is gevestigd dient de ammoniakemissie van het hele bedrijf lager te zijn dan voor de uitbreiding.

Wanneer een bedrijf op 2.000 m van een Natura 2000-gebied is gevestigd, hoeven er in Denemarken geen extra maatregelen te worden genomen bij uitbreiding. In Nederland is het type maatregelen die een bedrijf moet nemen niet direct afhankelijk van de afstand tot een Natura 2000-gebied. Het is in Nederland allemaal terug te voeren of het uitbreidende bedrijf te veel extra stikstofdepositie veroorzaakt in een stikstofgevoelig natuurgebied. Wanneer de extra depositie hoger is dan 1 mol of 0,014 kg per ha per jaar, dan dient het bedrijf extra maatregelen te nemen. Wanneer beschikbaar kan een bedrijf ontwikkelingsruimte verkrijgen, wat betekent dat een bedrijf een depositie mag veroorzaken van meer dan $1 \mathrm{~mol}$ per ha per jaar op het Natura 2000-gebied. De lokale overheid bepaalt hoeveel ontwikkelingsruimte er beschikbaar is (de maximale depositie mag dan in het algemeen $3 \mathrm{~mol}$ of 0,042 $\mathrm{kg}$ stikstof per ha per jaar bedragen). In Denemarken is de hoeveelheid ammoniak die een bedrijf na uitbreiding mag emitteren afhankelijk van het aantal buurbedrijven met vee; dat is niet het geval in Nederland. In Denemarken is het voor vleeskuikenbedrijven met buurbedrijven met vee niet mogelijk om uit te breiden, omdat de ammoniakemissie dan lager dient te zijn dan de meest vergaande techniek in de lijst van de Environmental Protection Agency van Denemarken.

De reguliere regelgeving voor ammoniakemissie voor opslag van mest en voor het aanwenden van mest zijn in Nederland strenger dan in Denemarken. Voor huisvestingssystemen is het net andersom. De regelgeving voor nieuw te bouwen huisvestingssystemen voor vleesvarkens min of meer vergelijkbaar tussen beide landen en voor melkvee zijn ze in Denemarken strenger:

- Een vleesvarkensbedrijf mag in Nederland in 2018 per dierplaats $1,24 \mathrm{~kg} \mathrm{NH}-\mathrm{N}$ emitteren en in Denemarken afhankelijk van de bedrijfsgrootte 1,5 tot $0,69 \mathrm{~kg}$. Omdat de definities van een vleesvarken tussen beide landen verschillen is een vergelijking per $\mathrm{m}^{2}$ beter. Dan is voor kleine en middelgrootte bedrijven ( $<4.750$ platsen) Nederland strenger en voor grote bedrijven (>4.750 plaatsen) Denemarken.

- Een melkveebedrijf mag in Nederland in 2018 per dierplaats 7,1 $\mathrm{kg} \mathrm{NH}_{3}-\mathrm{N}$ emitteren en in Denemarken $5,35 \mathrm{~kg}$.

- Een vleeskuikenbedrijf mag in Nederland in 2018 per dierplaats 0,029 kg NH$-\mathrm{N}$ emitteren en in Denemarken $0,031 \mathrm{~kg}$.

\section{S.3 Methode}

Het ministerie van milieu en voedsel van Denemarken heeft Wageningen Economic Research gevraagd de invloed te onderzoeken van ammoniakemissiemaatregelen ten behoeve van bescherming van natuurgebieden op veehouderijbedrijven in Nederland en Denemarken wanneer ze uitbreiden. In meer detail is het doel van de studie:

1. het verkrijgen van inzicht in de maatregelen die veehouderijbedrijven bij natuurgebieden dienen te nemen ten aanzien van ammoniakemissie bij uitbreiding van hun veestapel in Nederland en Denemarken.

2. het schatten van de kosten van die maatregelen voor beide landen.

3. het vergelijken van de Nederlandse met de Deense situatie.

Voor de analyse zijn statistische gegevens over de agrarische productie, maatregelen om de ammoniakemissie te reduceren en de kosten van die ammoniakemissiereductiemaatregelen verzameld. Voor Nederland is dat werk uitgevoerd door Wageningen Economic Research en Wageningen Livestock Research. Voor de Deense situatie zijn de gegevens verzameld en beschreven door de universiteit van Kopenhagen (Jacobson and Ståhl; versie 17 oktober 2017). Wageningen Economic research heeft de gegevens tussen beide landen met elkaar vergeleken en de conclusies geschreven.

De studie is gestart met het weergeven van een overzicht van de agrarische productie, die is gebaseerd op de landbouwtelling (CBS, 2017) en data van Statistics Denmark (2016). Er wordt 
eveneens een overzicht en beschrijving gegeven van de nationale maatregelen van ammoniakemissie voor beide landen.

De extra ammoniakreductiemaatregelen die bedrijven bij Natura 2000-gebieden en andere natuur dienen te nemen zijn tot in detail geanalyseerd. De kosten van de ammoniakreductiemaatregelen bedrijven in de nabijheid van Natura 2000-gebieden dienen te maken bij uitbreiding van hun veestapel zijn berekend voor drie voorbeeldbedrijven (zie bijlage 1):

1. een bedrijf met een productie van 7.200 vleesvarkens per jaar dat uitbreidt naar 14.400 geproduceerde vleesvarkens per jaar.

2. Een bedrijf met 120 melkkoeien dat uitbreidt naar 240 melkkoeien.

3. Een bedrijf met een productie van 300.000 vleeskuikens per jaar dat uitbreidt naar 600.000 geproduceerde vleeskuikens. 


\section{Introduction}

\section{$1.1 \quad$ Reference}

The Ministry of Environment and Food of Denmark requested Wageningen Economic Research to compare the economic impacts of measures to control ammonia emissions on animal production systems near nature areas in the Netherlands with those in Denmark.

More specifically, the Ministry of Environment and Food of Denmark asked for:

1. A brief overview of agriculture production, including the use of agricultural land in the Netherlands and Denmark, complemented with a short overview of agricultural production related to and located near nature areas.

2. An overview of specific ammonia-reducing measures that animal production farms (i.e. finishers, dairy cows and broiler farms) have to take when they want to expand their production capacity in the Netherlands and Denmark. An expansion of $100 \%$ of the production capacity is considered for holdings that are either within $400 \mathrm{~m}$ or $2,000 \mathrm{~m}$ of a designated nature habitat. The focus is on three case farms near Natura 2000 areas and one case farm near other nature.

3. An assessment of the accumulated costs of these measures in the Netherlands and Denmark for the aforementioned case farms, including a discussion and conclusion of the results.

\subsection{Objective}

The objective is:

1. to gain insight into the measures that animal farms that are located near nature areas have to take with respect to reducing ammonia emissions when they expand their animal production, both in the Netherlands and Denmark.

2. to assess the costs related to these measures in both countries.

3. to compare the Dutch and Danish situation.

\subsection{Approach and content of the report}

For the analysis, statistic data concerning the agricultural production, the ammonia-reduction measures and the cost of ammonia-reduction measures have been collected. For the Dutch situation, this is done by Wageningen Economic Research and Wageningen Livestock Research. For the Danish situation, this data are collected and described by the University of Copenhagen (Jacobson and Ståhl; version 17 October 2017). Wageningen Economic Research compared the information of both countries and drew conclusions.

Chapter 2 of this report describes the starting points and method. Chapter 3 provides a brief overview of the agriculture production in the Netherlands and in Denmark. Chapter 4 gives an overview of the ammonia-reduction measures in both countries. Chapter 5 presents the cost of ammonia-reduction measures at farm level in both countries. Chapter 6 draws the conclusions. 


\section{Data sources and method}

\subsection{Brief overview of agricultural production}

For the analysis of a brief description of the agricultural production and the use of agricultural land in the Netherlands data of the National Agricultural Census (CBS, 2017) and Denmark data from Statistics Denmark (2016) are used. For the most relevant types of livestock production, the average farm size, number of farms per type and the export of agricultural products data have been collected. Furthermore, the number of farms that are located in the proximity of Natura 2000 areas and of other nature areas have been collected. For the Netherlands this is done with GIS. For Denmark the University of Aarhus has made an analysis of distance from livestock to different types of nature. Special attention is given to livestock production farms statistics, such as the number of farms, number of animals, farm size and farm type.

\subsection{Overview of ammonia-reduction measures}

The briefly described national ammonia-emission regulations in the Netherlands and Denmark are connected with the project of the university of Utrecht for Denmark (Backus, 2017). The extra ammonia regulations for farms located near Natura 2000 and other nature areas are gathered from the ammonia emission laws of the Dutch and Danish governments and possible economic compensation is analysed. In the Netherlands, provinces (regional government bodies) are responsible for the implementation of nature policies and the regulation of ammonia emission close to nature habitats. The implementation differs between provinces. For the Netherlands, this study's focus is on the province of Overijssel; this province is representative as far as cattle husbandry and share of nature (Natura 2000 and other nature areas) are concerned.

\subsection{Costs of ammonia-reduction measures at farm level}

The costs of the ammonia-reduction measures that a farm has to take in case of expansion of their livestock farm in the proximity of Natura 2000 areas are calculated for three case farms chosen by the Ministry of Environment and Food of Denmark (Appendix 1):

1. A farm with 7.200 finishers annually that is expanding to 14,400 finishers

2. A farm with 120 dairy cows annually expanding to 240 dairy cows

3. A farm with 300.000 broilers annually expanding to 600,000 broilers.

Per farm six variants are distinguished based on two distance levels (400 and 2,000 m) from a Natura 2000 area and two levels of room for ammonia deposition in the Netherlands (see Section 4.1.3 for more information on room for increase of ammonia deposition).

In Denmark, the ammonia emissions that are allowed taking into account the Natura 2000 areas depends on whether or not there are holdings in the vicinity. In the Netherlands, this depends on the available room for ammonia deposition. The analysis will consider situations where enough room for ammonia deposition is available for a farm to increase the livestock production and for situations where there is not enough room for ammonia deposition to increase the livestock production.

Costs for ammonia-reduction measures of farms near other nature areas are only described for the case farm producing finishers. 
The measures the case farms have to take when they expand and are located outside the influence zones of the nature areas, are described. For the Dutch situation the description is based on Van Bruggen et al. (2017, Emissies naar lucht uit de landbouw 2015).

Through a literature study of the Dutch and Danish ammonia emission laws, a brief description is given of the extra measures expanding case farms have to take when they are located within the influence of Natura 2000 areas or other nature areas. The extra costs for these case farms are calculated and compared with the costs of expanding case farms that are located outside the influence zones of nature areas. 


\section{Brief overview of agricultural production}

This chapter describes the agricultural production in the Netherlands (Section 3.1) and Denmark (Section 3.2), including both the arable and the livestock sector and the most relevant farm types Both the overall production and the share of the production that is exported, are shown. This chapter also discusses agricultural production close to Natura 2000 areas and the key issues related to this with regard to increasing the livestock production.

\subsection{The Netherlands}

\subsubsection{General}

Dutch farms are continually scaling up. Consequently, the number of farms declined in six years by almost $25 \%$ to 55,681 farms in 2016 (Table 3.1 ). About $15 \%$ of them are part-time farms ( $<25,000$ SO). The utilised agricultural area in 2016 has decreased by $4 \%$ since 2010 and the number of animals is slightly higher, especially cattle.

In 2016, the utilised agricultural area in the Netherlands was almost $1.8 \mathrm{~m}$ ha, of which $1.0 \mathrm{~m}$ ha is grassland and $0.8 \mathrm{~m}$ ha is arable crops (Table 3.1). Seventy-one per cent of all the grassland is permanent.

In 2016, Dutch cattle amounted to $4.3 \mathrm{~m}$ animals, of which $1.7 \mathrm{~m}$ were dairy cows and $1.3 \mathrm{~m}$ were young dairy cattle. The remainder mainly consisted of veal calves. Other grazing animals that are kept in the Netherlands are sheep (784,000 in 2016) and goats (500,000 in 2016). The number of pigs in the Netherlands in 2016 was $12.5 \mathrm{~m}$, of which $5.7 \mathrm{~m}$ were finishers and $0.9 \mathrm{~m}$ were sows. The number of chickens in 2016 was $105.6 \mathrm{~m}$ : $46.2 \mathrm{~m}$ laying hens and $49.2 \mathrm{~m}$ broilers (Table 3.1 ). Farms with pigs and chickens are mainly concentrated in the sandy regions in the southern and eastern parts of the Netherlands. Cattle can be found anywhere in the Netherlands, except in the typical arable areas in the southwestern part of the Netherlands, the IJsselmeerpolders and the northeastern coastal zone. Figure 3.1 shows the livestock density in the Netherlands at municipality level. All municipalities with a level of more than 1 had to transport a part of the produced manure in their municipality to other regions. There are a few municipalities who had to transport more than $80 \%$ of the manure production to other areas. 
Table 3.1 Data of Dutch agriculture, 2010 and 2016 (average number of animals per year)

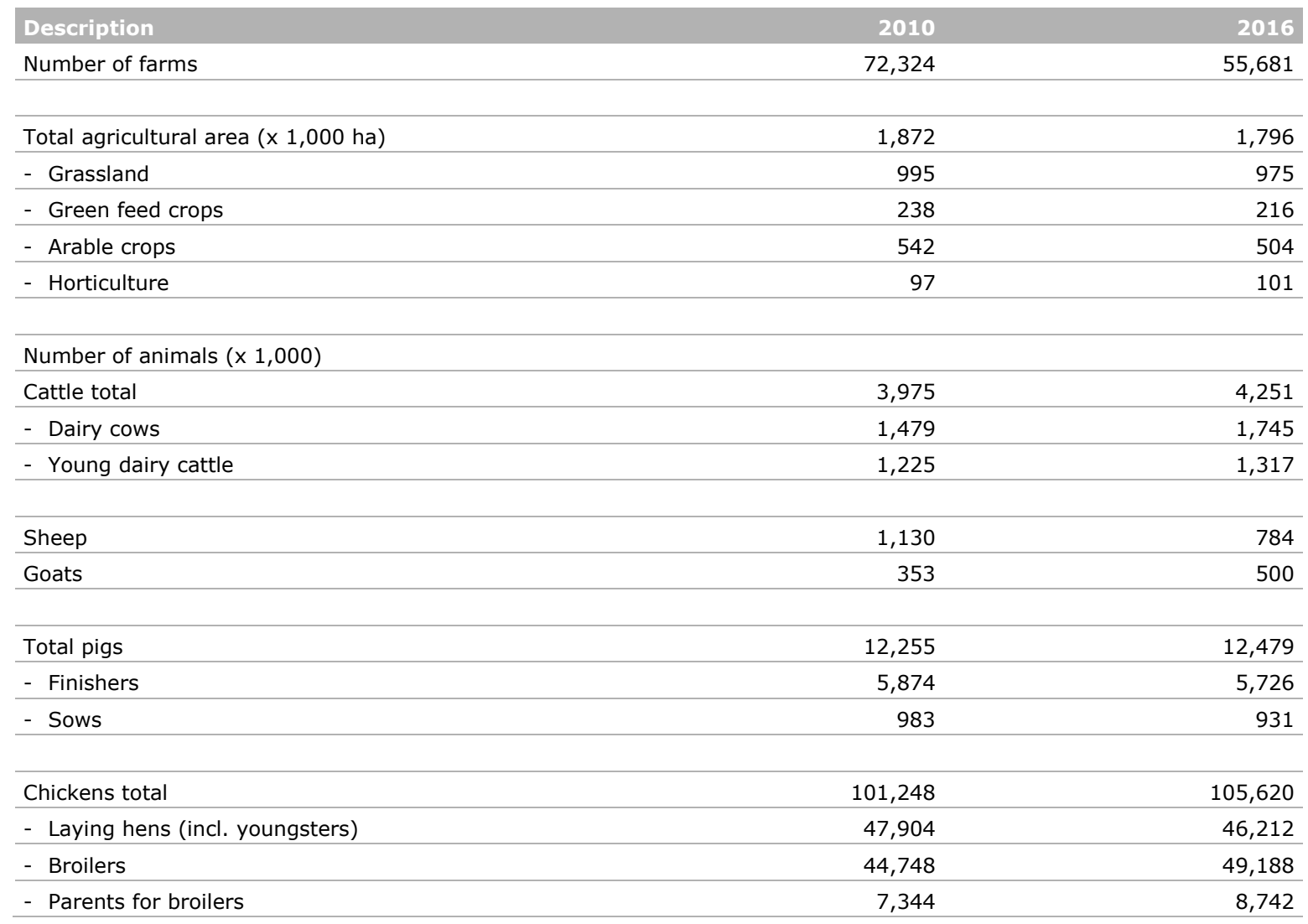

Source: Dutch National Agricultural Census (CBS, 2017). 


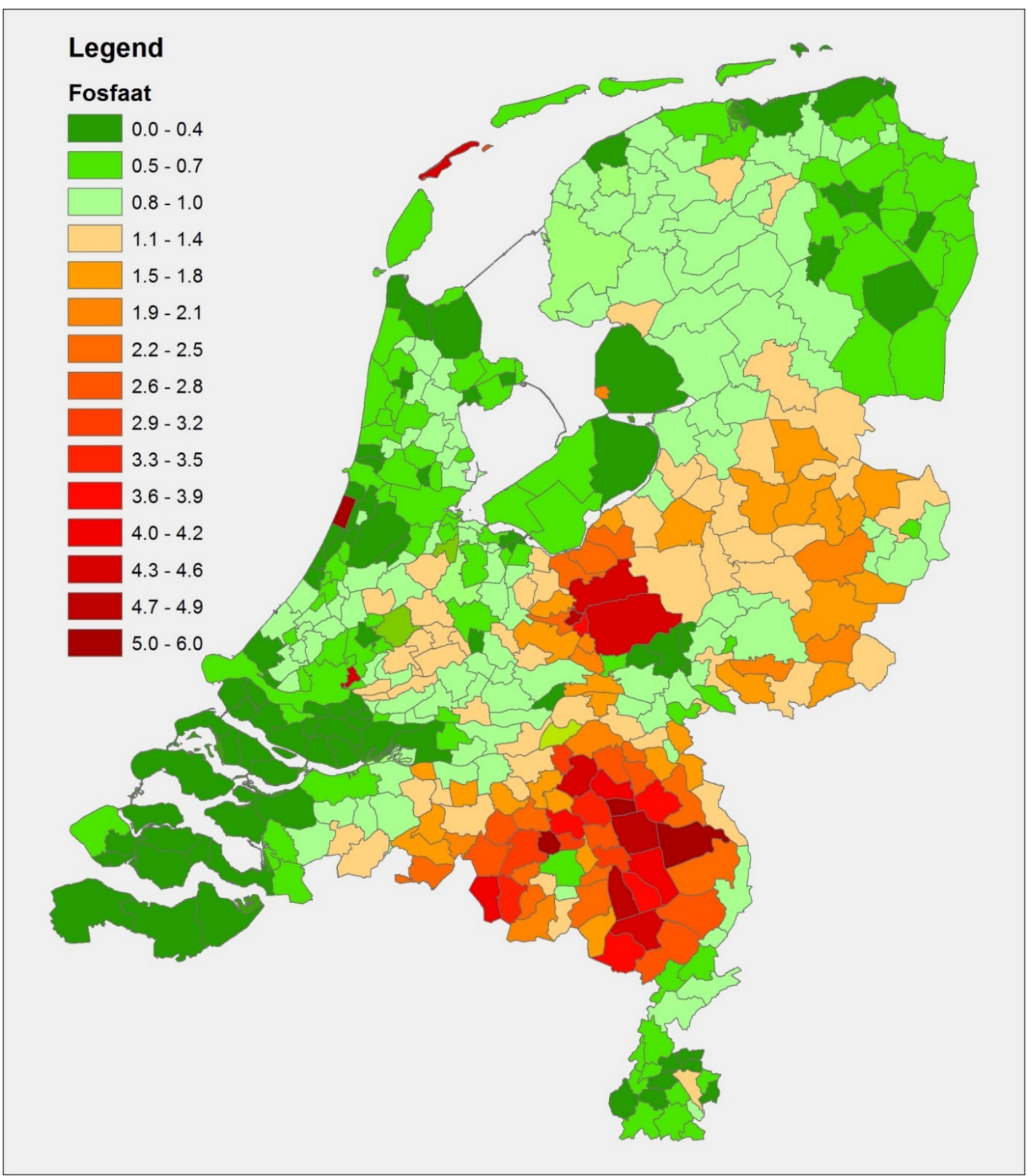

Figure 3.1 Phosphate production divided by the placing room for phosphate per municipality in 2012 Source: www.agrimatie.nl.

On average, the 16,500 dairy farms in 2016 used 52 ha of agricultural land and kept 101 milking cows (Table 3.2). In 2016, there were 1,600 finisher farms for pigs, 800 breeding farms for pigs and almost 700 closed pig farms (integrated production of sows and finishers) in the Netherlands. The farms for finishers generally are quite small, with almost 2,000 finishers per farm. The closed pig farms are bigger, with an average of 2,500 finishers and more than 400 sows. In 2016, the average laying hen farm has 65,000 laying hens and the average broiler farm has almost 100,000 broilers (Table 3.2). 
Table 3.2 Number of farms per farm type and the average size in utilised agriculture area and number of animals per farm in The Netherlands in 2016

\begin{tabular}{|c|c|c|c|c|c|c|c|}
\hline Description & $\begin{array}{l}\text { Number } \\
\text { of farms }\end{array}$ & $\begin{array}{r}\text { Culture } \\
\text { area } \\
\text { (ha/farm) }\end{array}$ & $\begin{array}{r}\text { Dairy cows } \\
\text { (number/ } \\
\text { farm) }\end{array}$ & $\begin{array}{r}\text { Finishers } \\
\text { (number/ } \\
\text { farm) }\end{array}$ & $\begin{array}{r}\text { Sows } \\
\text { (number/ } \\
\text { farm) }\end{array}$ & $\begin{array}{r}\text { Laying hens } \\
\text { (number/ } \\
\text { farm) }\end{array}$ & $\begin{array}{r}\text { Broilers } \\
\text { (number / } \\
\text { farm) }\end{array}$ \\
\hline Horticulture farms & 7,389 & 12 & & & & & \\
\hline Remaining culture farms & 1,612 & 14 & & & & & \\
\hline Shed animal farms & 4,837 & 13 & & 1,062 & 185 & 8,946 & 9,339 \\
\hline - Finishers & 1,648 & 11 & & 1,942 & & & \\
\hline - Breeding farms & 806 & 12 & & 159 & 707 & & \\
\hline - Other pig farms & 681 & 20 & & 2,526 & 431 & & \\
\hline Cattle combination farms & 607 & 34 & 52 & 527 & 34 & 3,112 & 2,340 \\
\hline $\begin{array}{l}\text { All other combination } \\
\text { farms }\end{array}$ & 1,429 & 45 & 16 & 102 & 10 & 452 & 1,732 \\
\hline Total/average & 55,681 & 32 & 31 & 103 & 17 & 830 & 883 \\
\hline
\end{tabular}

Source: Dutch National Agricultural Census (CBS, 2017).

\subsubsection{Export of livestock products}

In 2015 , the Dutch livestock export value was almost $€ 16 \mathrm{bn}$ and was primarily (55\%) based on cattle products (Table 3.3). Pig related products made up $20 \%$ of the export value.

Table 3.3 Export value of Dutch livestock products in 2015

\begin{tabular}{|c|c|c|}
\hline Product & Value in million $\mathbf{C}$ & Share $(\%)$ \\
\hline Eggs and egg products & 937 & 6 \\
\hline Cheese & 3,108 & 20 \\
\hline Cattle meat and their meat products & 2,488 & 16 \\
\hline Living pigs & 833 & 5 \\
\hline Poultry meat and their meat products & 2,904 & 18 \\
\hline Total & 15,711 & 100 \\
\hline
\end{tabular}

Source: CBS (2017), adapted by Wageningen Economic Research.

\subsubsection{Agriculture production near nature}

Natura 2000 is a network of protected nature areas in the EU. The areas preserve and protect habitat types and wild animals and plants that are rare, endangered or characteristic for EU countries. Natura 2000 sites cover habitat, bird-protection and Ramsar sites and they have been designated in order to protect specific species and habitats. The basis for Natura 2000 is the EU Birds Directive and Habitats Directive. These Directives dictate EU Member States to preserve selected species and habitats.

For the location of the Natura 2000 areas and other nature see Figure 3.2. Only a small amount of the Dutch utilised agriculture area lies within $400 \mathrm{~m}$ of one or more Natura 2000 areas. The same accounts for the number of animals that is kept within the proximity of Natura 2000 (Figure 3.3 and Appendix 2). Almost $30 \%$ of the agricultural area, $28 \%$ of the dairy cows, $18 \%$ of the finishers and $17 \%$ of the broilers in The Netherlands are located within 2,000 m of at least one Natura 2000 area. Somewhat $45 \%$ of the Dutch agriculture farms are located within 2,000 $\mathrm{m}$ of other nature; this is also the case for $53 \%$ of the dairy cows, $51 \%$ of the finishers and $42 \%$ of the broilers (Figure 3.3 and Appendix 2). This means that only $20 \%$ of the dairy cows, $30 \%$ of the finishers and $40 \%$ of the broilers are kept in farms that are located at more than 2,000 $\mathrm{m}$ from nature. 


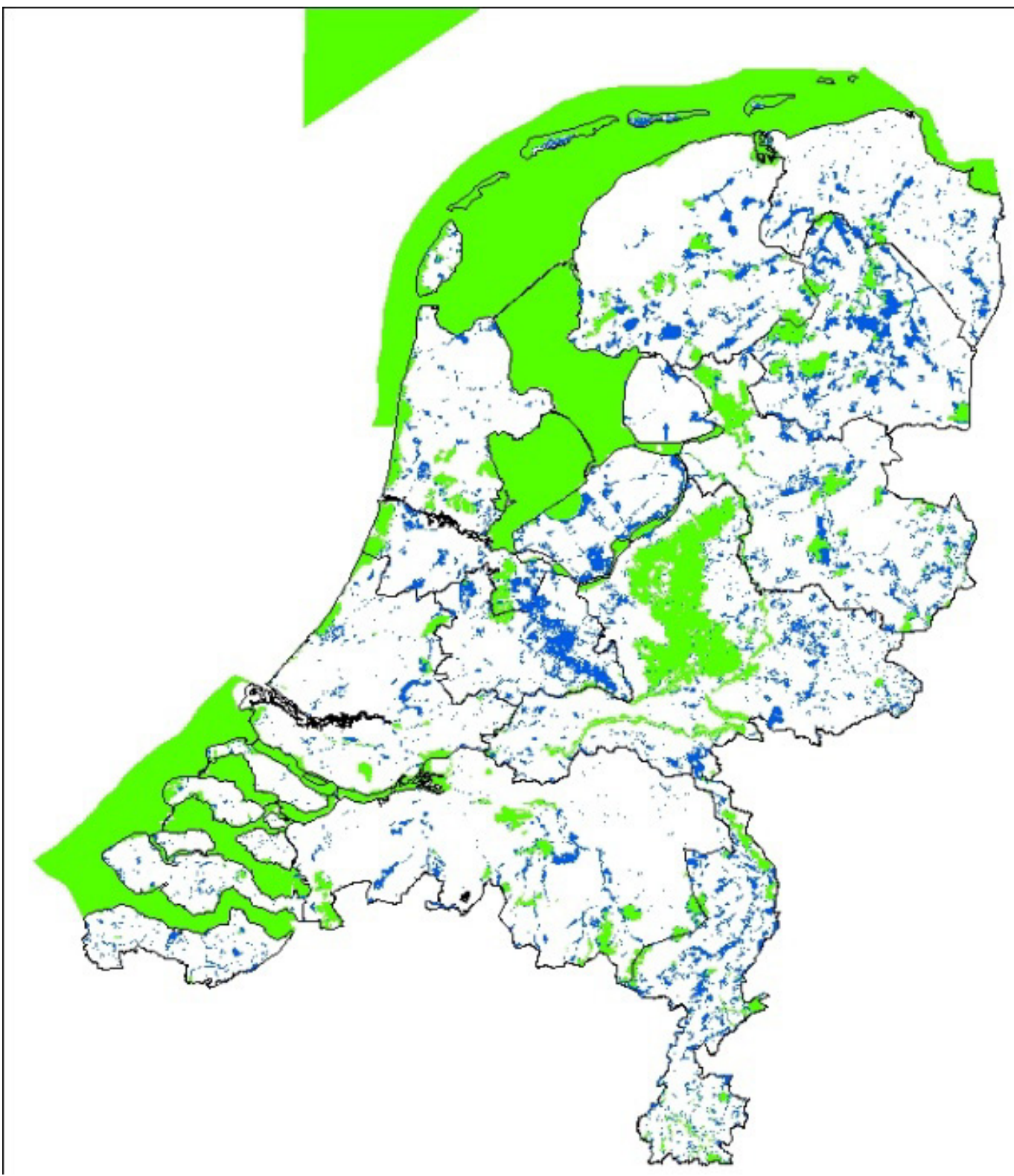

Figure 3.2 Location of Natura 2000 areas (green) and other nature (blue) in the Netherlands

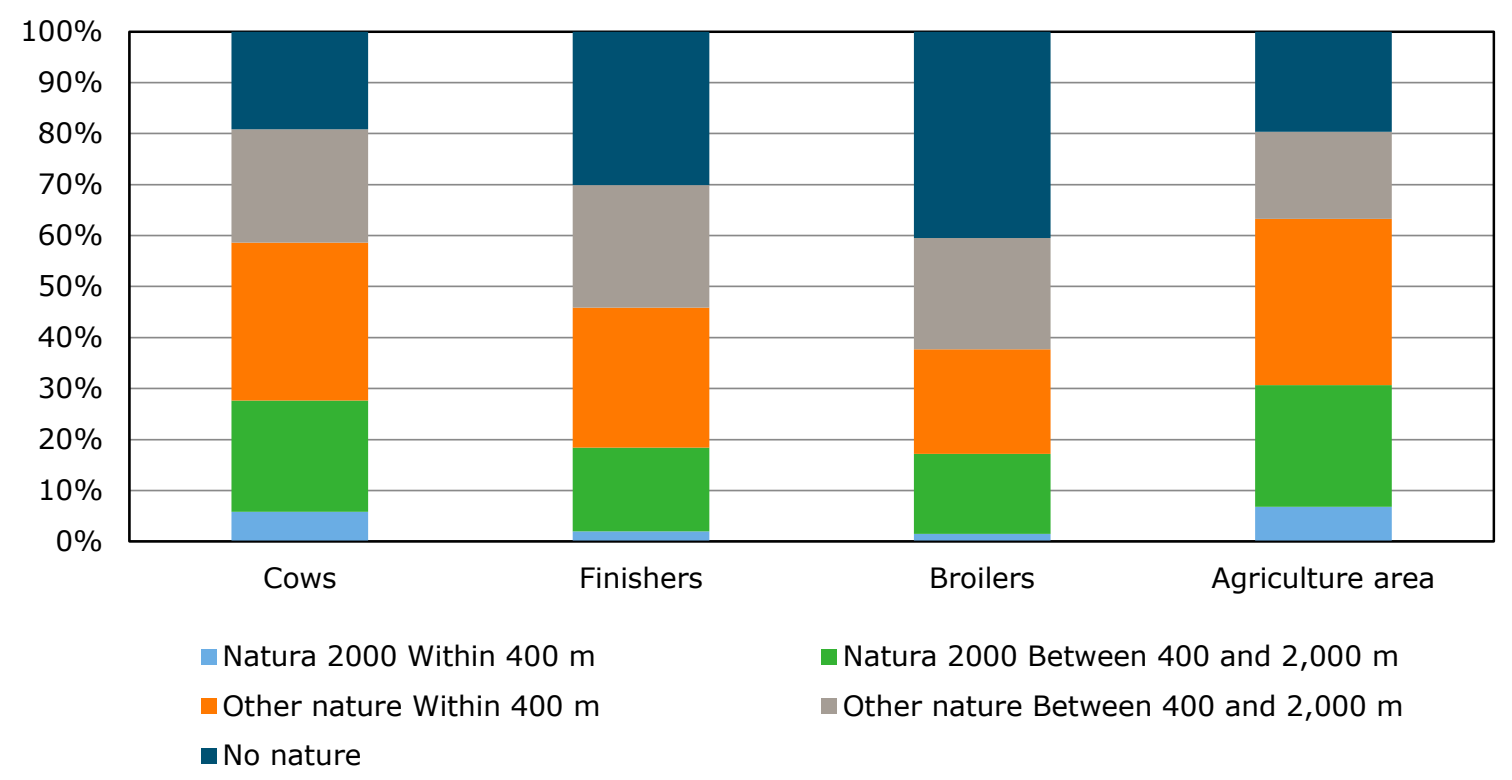

Figure 3.3 Agriculture area (\%) and amount of animals (\%) located near nature areas in the Netherlands in 2016

Source: Dutch National Agricultural Census (CBS, 2017), adapted by Wageningen Economic Research. 
The number of farms per farm type and location (Figure 3.4 and Appendix 2) roughly has the same pattern as the number of animals. When it comes to finishers and broilers, a relative bigger part of the farms than of the animals is located near nature areas. This has to do with the fact that farms located near nature are generally smaller than farms located further away from nature areas (see also Figure 3.5).

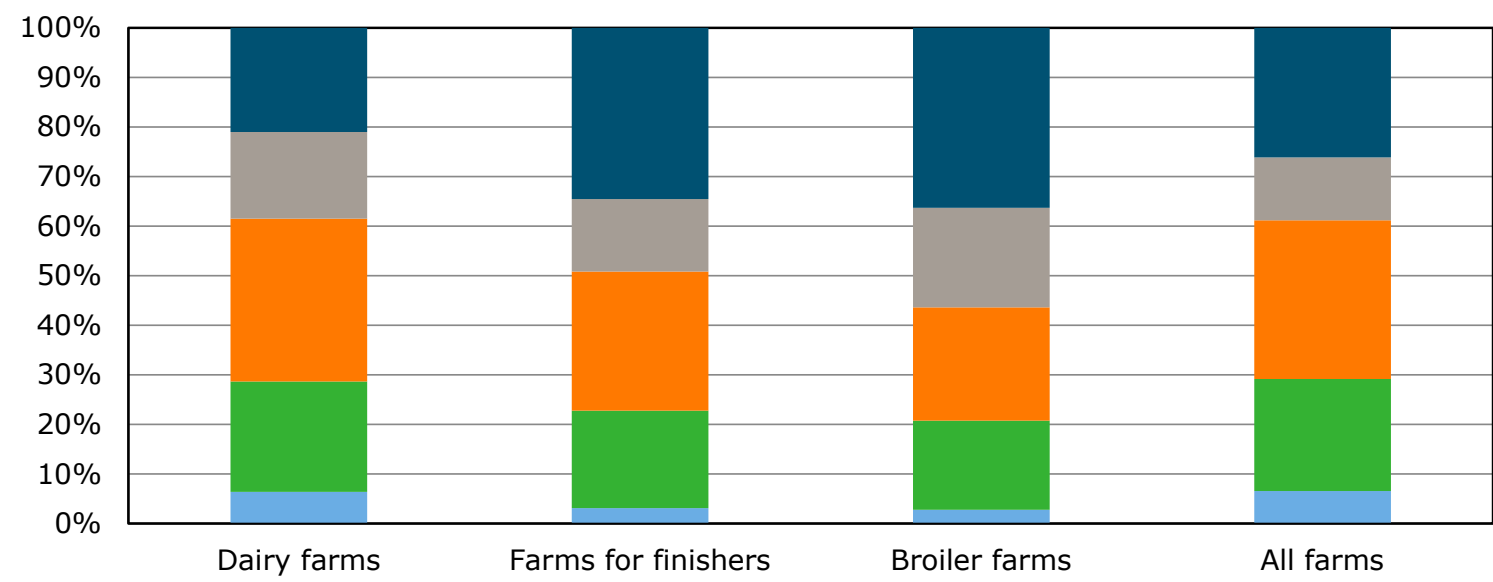

Natura 2000 Within $400 \mathrm{~m}$ Other nature Within $400 \mathrm{~m}$ - No nature
Natura 2000 Between 400 and 2,000 m

Other nature Between 400 and 2,000 m

Figure 3.4 Amount of farms (\%) per farm type and all farms located near nature in the Netherlands in 2016

Source: Dutch National Agricultural Census (CBS, 2017), adapted by Wageningen Economic Research.

Farms for finishers and broilers located at less than $400 \mathrm{~m}$ away from Natura 2000 areas are almost half the size of the Dutch average farm size (Figure 3.5). Farms for finishers and broilers that are located between 400 and 2,000 m of Natura 2000 areas, are about $80 \%$ of the size of the Dutch average. Farms that are located near other nature tend to have almost the same farm size as the Dutch average, except for farms for finishers located between $400 \mathrm{~m}$ and 2,000 $\mathrm{m}$ from other nature. These farms are more than $20 \%$ bigger on average (Figure 3.5). For dairy farms, the size is almost similar regardless of the proximity of nature.

\section{Dutch average $=100$}

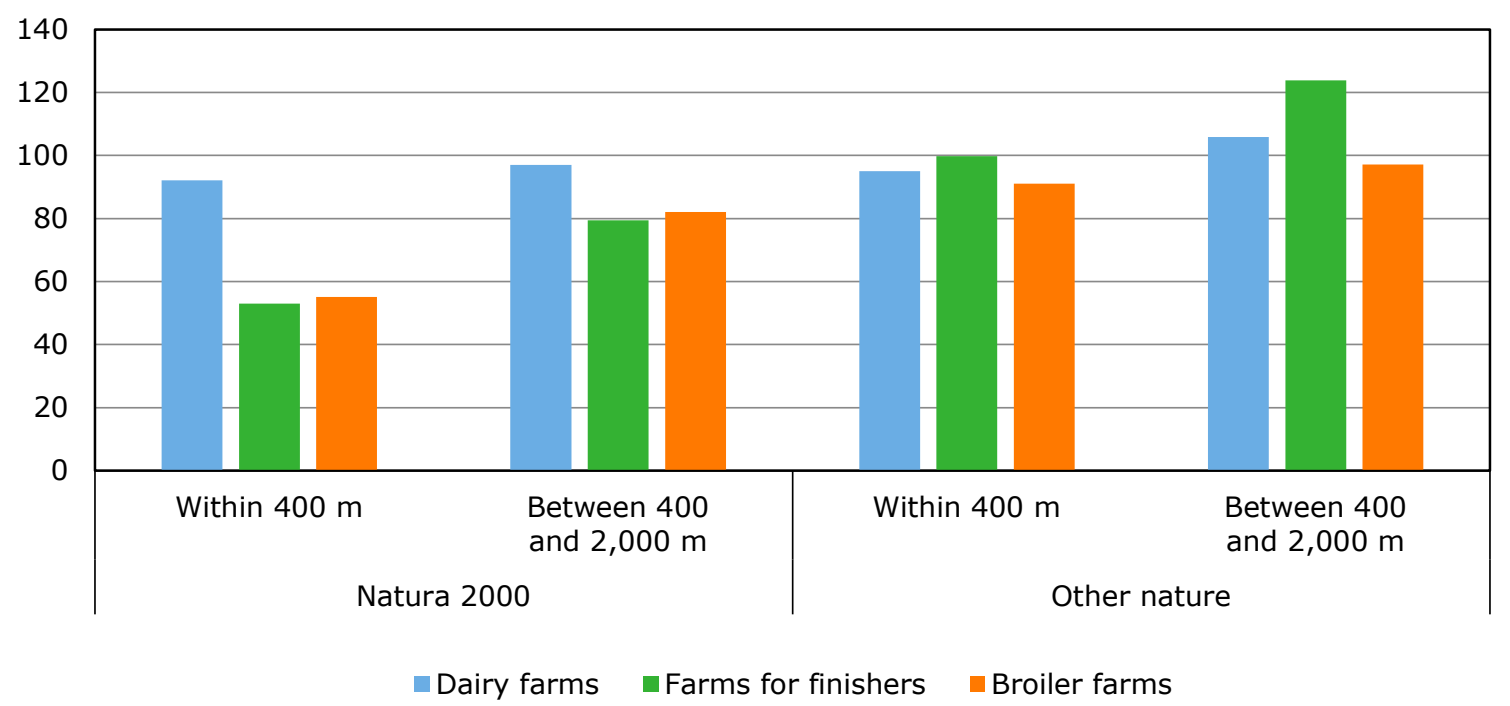

Figure 3.5 Farm size of farms for dairy, finishers and broilers near nature areas Source: Dutch National Agricultural Census (CBS, 2017), adapted by Wageningen Economic Research. 


\subsection{Denmark}

\subsubsection{General}

The number of farms, the use of the total agricultural area and the total livestock production is shown in Table 3.4. The total number of farms has fallen over the years and is now around 36,000 farms. Just under 10,000 farms are today considered as full-time farms (work load over 1665 hrs. per year).

Table 3.4 Data of the Danish Agricultural production, 2010 and 2016

\begin{tabular}{|c|c|c|}
\hline Description & 2010 & 2016 \\
\hline Number of farms & 42,099 & 35,674 \\
\hline - Grassland & 200 & 230 \\
\hline - Green feed crops & 560 & 510 \\
\hline - Horticulture & 20 & 20 \\
\hline \multicolumn{3}{|l|}{ Number of animals $(x 1,000)$} \\
\hline Cattle total & 1,571 & 1,568 \\
\hline Total pigs & 29,908 & 27,156 \\
\hline - Finishers (slaughtered) & 20,244 & 17,742 \\
\hline - Sows & 1,117 & 999 \\
\hline Chickens total & 18,084 & 17,898 \\
\hline - Laying hens (incl. youngsters) & 3,900 & 4,644 \\
\hline - Broilers & 12,836 & 11,745 \\
\hline
\end{tabular}

Source: Statistics Denmark (2016).

The total Danish area is $4,3 \mathrm{~m}$ ha, of which $2,63 \mathrm{~m}$ ha are cropped. So in total, around $60 \%$ of the entire area is cropped, which is relatively high in a European setting. Most of the cropped area is in rotation and the share with permanent grass is limited $(8 \%)$.

Danish farmers produce 18-20m slaughter hogs per year. The number has been going down over recent years as the export of live pigs has increased to over $13 \mathrm{~m}$. The milk production amounts to around 5,4bn kg from around 570,000 dairy cows in 2016. The number of cows has until 2015 declined, but there was a small increase in relation to the abolishing of the milk quota in 2015. Besides the production of milk and pork Denmark produces poultry and mink. Generally, two thirds of the Danish agricultural production is exported.

The livestock density is the highest in Jutland in selected parts of the region. The most intensive regions are pig farming regions in the northwest of Jutland and the Southeast of Jutland. The dairy farms are mainly located on sandy soils and especially in the south western part of Jutland.

The number of farms in Table 3.5 are all fulltime farms, which means that the annual workload on the farm is over 1,665 hrs. per year. The farms are divided according to which production have the main economic activity (over 50\%) based on the standard economic gross margin (SGM). 
Table 3.5 Number of conventional fulltime farms per farm type and the average size in agriculture area and number of animals per farm in Denmark in 2015

\begin{tabular}{|c|c|c|c|c|c|c|c|}
\hline Description & $\begin{array}{l}\text { Number } \\
\text { of farms }\end{array}$ & $\begin{array}{r}\text { Culture } \\
\text { area } \\
\text { (ha/farm) }\end{array}$ & $\begin{array}{r}\text { Dairy cows } \\
\text { (number/ } \\
\text { farm) }\end{array}$ & $\begin{array}{r}\text { Finishers } \\
\text { (number/ } \\
\text { farm) }\end{array}$ & $\begin{array}{l}\text { Sows } \\
\text { (number } \\
\text { /farm) }\end{array}$ & $\begin{array}{r}\text { Laying hens } \\
\text { (number/ } \\
\text { farm) }\end{array}$ & $\begin{array}{r}\text { Broilers } \\
\text { (number/ } \\
\text { farm) }\end{array}$ \\
\hline Horticulture farms a) & 723 & 40 & & & & & \\
\hline - Dairy farms & 2,860 & 154 & 179 & & & & \\
\hline Pigs & 2,520 & 166 & & & & & \\
\hline Finishers & 1,215 & 158 & & 9,870 & & & \\
\hline Pig breeding & 855 & 120 & & & 842 & & \\
\hline Integrated pig product. & 451 & 272 & & & 435 & & \\
\hline Poultry b) & 276 & 148 & & & & & \\
\hline Other farms & 1,783 & 43 & & & & & \\
\hline Total (including organic) & 11,499 & 167 & & & & & \\
\hline
\end{tabular}

a) could contain organic cultivation; b) conventional and organic.

Source: Statistics Denmark.

As shown in Table 3.5, the number of full-time farms today is around 10,000 and the total number of farms is around 35,000 . The full-time farms of Table 3.5 utilise about $1.8 \mathrm{~m}$ ha $(68 \%)$ and the large majority of the total livestock production. The farms that focus on milk production have on average 179 cows and the pig farms with only sows have around 840 sows per farm.

\subsubsection{Export of livestock products}

The total value of the export of Danish livestock products in 2015 is shown in Table 3.6. The dairy products constitutes around $40 \%$ of the value and the pig related products around $56 \%$ of the total value.

Table 3.6 Export value of Danish livestock products in 2015

\begin{tabular}{lrr} 
Product & Value in million $~$ & Share (\%) \\
Eggs and egg products & 62 & 1 \\
\hline Cheese & 1,303 & 21 \\
\hline Other dairy products & 768 & 12 \\
\hline Cattle meat and their meat products & 333 & 5 \\
\hline Living pigs & 844 & 13 \\
\hline Pig meat and their meat products & 2,690 & 43 \\
\hline Poultry meat and their meat products & 305 & 5 \\
\hline Total & 6,305 & 100 \\
\hline
\end{tabular}

Source: Statistics Denmark.

\subsubsection{Agriculture production near nature}

A total of 252 Natura 2000 sites have been designated in Denmark (Figure 3.6). Together these sites cover an area corresponding to the size of the Danish island of Funen and its surrounding islands (8\%). The basis for Natura 2000 is the EU Birds Directive and Habitats Directive and so the habitat and bird-protection sites have been designated in order to protect specific species and habitats. 


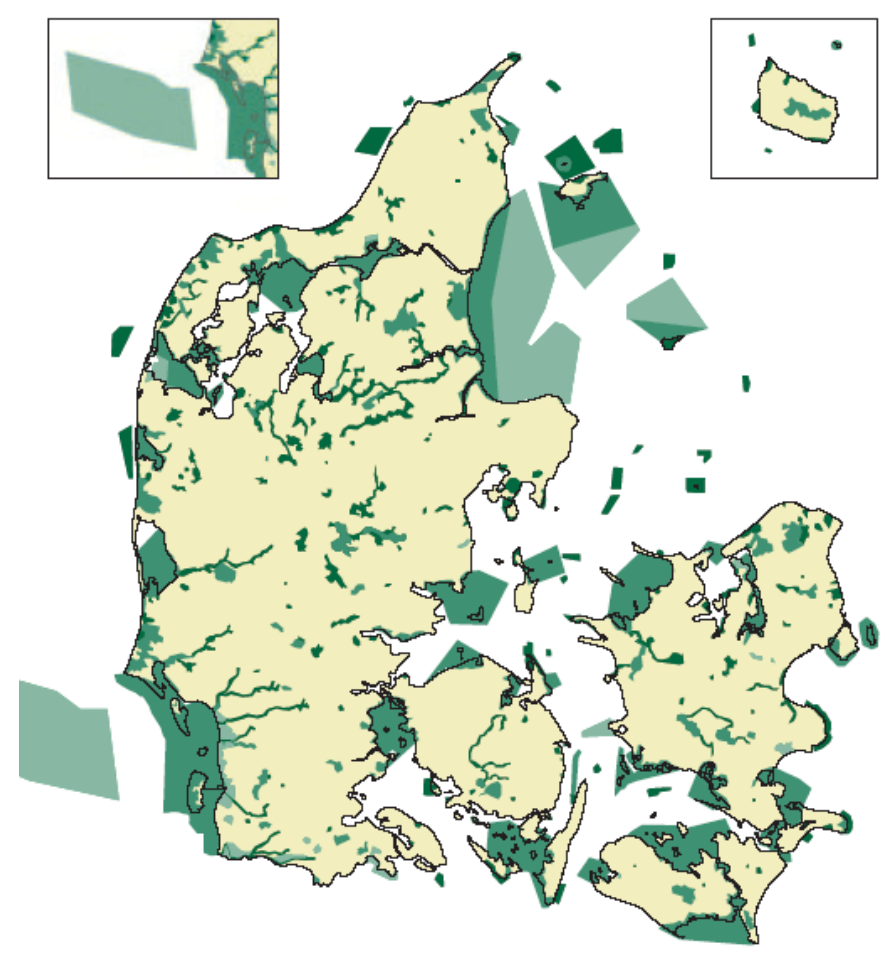

Figure 3.6 Location of Natura 2000 areas in Denmark

As shown in Figure 3.6, which includes Natura 2000 areas at sea and on land, the areas are scattered over the whole country. The total Natura 2000 area on land is around 260,000 ha. It has been calculated that the Natura 2000 sites on land include around 120,000 ha of ammonia-sensitive nature. The Environmental Agency have found that the total agricultural area within Natura 2000 sites is 7285,000 ha depending on whether only intensive or also extensive farm areas are included (Jacobsen et al., 2017).

The environmental Agency has suggested changes with respect to the Natura 2000 areas in Denmark in 2017 so that around 21,000 ha of agricultural area (25\%) is expected to be taken out of Natura 2000 areas and that around 1,100 ha of agricultural area is expected to be included. The area included in the future Natura 2000 map is located at some distance from current livestock operations and so it will rarely have an impact on the present livestock operations. The purpose is to take agricultural area with relative low nature value out of the Natura 2000 mapping and include more nature (4,000 ha nature area is included). The corrections are also linked to the transformation from hand drawn maps to digitised maps, why many of the changes are very small. Agricultural area is here defined as area eligible for basic land payment (area payment).

The distance from livestock production to ammonia-sensitive nature in the Natura 2000 sites is shown in Table 3.7. As shown in Table 3.7, a limited share of the livestock production is closer than $500 \mathrm{~m}$ to Category $1(5 \%)$ and $2(6 \%)$ nature. (For nature types see Figure 4.5.) For Category 3 nature, around $48 \%$ of the livestock production is within $500 \mathrm{~m}$. 
Table 3.7 Share of total livestock production (LSU) near Category 1, 2 and 3 nature, \% a)

\begin{tabular}{|c|c|c|c|c|}
\hline Distance $(\mathrm{m})$ & $\begin{array}{r}\text { Cat_1_Nature } \\
\text { (separate) }\end{array}$ & $\begin{array}{l}\text { Cat_1_Forest } \\
\text { (separate) }\end{array}$ & $\begin{array}{r}\text { Cat_2_Nature } \\
\text { (separate) }\end{array}$ & $\begin{array}{r}\text { Cat_3_Nature } \\
\text { (separate) }\end{array}$ \\
\hline$<200$ & 1 & 0 & 2 & 13 \\
\hline $500-750$ & 3 & 1 & 5 & 22 \\
\hline $750-1,000$ & 3 & 1 & 6 & 14 \\
\hline \multirow[t]{2}{*}{$>2,000$} & 76 & 90 & 59 & 2 \\
\hline & 100 & 100 & 100 & 100 \\
\hline
\end{tabular}

a) See Figure 4.5 for nature categories.

Source: Jacobsen et al. (2017).

As shown in Table 3.7, most livestock farms are more than 1,000 $\mathrm{m}$ away from nature. When Category 1 and 2 are combined with the four distance classes up to $1,000 \mathrm{~m}$, then $27 \%$ of the farms are within $1,000 \mathrm{~m}$ of nature Category 1 and 2 . This also means that $73 \%$ of the farms are located further away than 1,000 $\mathrm{m}$ from nature of Category 1 and 2. However, when Category 3 nature is included, only $14 \%$ of the livestock production is more than $1,000 \mathrm{~m}$ from all nature categories (1-3).

Livestock farms located closer than $1,000 \mathrm{~m}$ to Category 1 and 2 nature are found to be 20 LSU $(10-14 \%)$ smaller than the average for farms further than 1,000 $\mathrm{m}$ away. There is no clear difference with respect to size of livestock farms in relation to Category 3 nature.

\subsection{Comparison of the Netherlands with Denmark}

The agriculture area of Denmark is 870,000 ha larger (almost 50\%) than the Dutch agricultural area. The area of arable crops in Denmark is $1.9 \mathrm{~m}$ ha, whereas that of the Netherlands $0.6 \mathrm{~m}$ ha. About $59 \%$ of the $1.2 \mathrm{~m}$ ha of fodder crops (grass and maize) in the Netherlands is permanent grassland; in Denmark only $8 \%$ of the $0.8 \mathrm{~m}$ ha of fodder crops is permanent grassland.

The number of pigs in Denmark is about 13\% higher than in the Netherlands, but there are about three times more dairy cows and six times more poultry in the Netherlands. There is a big difference in farm size between the Netherlands and Denmark. In 2016, there were almost 56,000 farms in the Netherlands and almost 36,000 in Denmark, whereas the total agriculture area in Denmark is $50 \%$ higher. As a result, the average farm in Denmark has 74 ha of land and in the Netherlands 32 ha. When it comes to pig and poultry farms, the differences between the Netherlands and Denmark are huge. In the Netherlands, these farms have on average 13 ha of utilised agriculture area; in Denmark, they have about 150 ha. Also, the number of animals per farm in Denmark is higher than in the Netherlands; dairy farms have $80 \%$ more cows, finishers and broiler farms have five to seven times more animals. On pig breeding farms however, the number of sows per farm is almost the same in both countries.

With more animals (dairy cows and poultry) in the Netherlands and 50\% more agricultural area in Denmark, the manure pressure in the Netherlands is much higher than in Denmark. This is strengthened by the fact that pig and poultry farms are concentrated in just a few regions in the Netherlands.

The situation of livestock production near nature seems to be similar in both countries. In both countries less than $5 \%$ of the livestock production is located closer than $400 \mathrm{~m}$ to Natura 2000 areas. However, the Netherlands differs from Denmark in that more farms in Denmark are further away than $2,000 \mathrm{~m}$ from nature than in the Netherlands (about $25 \%$ of the farms in the Netherlands and $45 \%$ of the farms in Denmark). 


\section{$4 \quad$ Ammonia-reduction measures}

\subsection{The Netherlands}

\subsubsection{Regular ammonia-emission regulation}

For many years now, there has been a surplus of nitrogen (ammonia and nitrogen oxides) in Natura 2000 areas. This is harmful to nature and also hinders the issuing of permits for economic activities. Therefore, the Dutch Government has taken the initiative to address these nitrogen issues.

\section{Application and storage}

A ban on manure surface spreading came into force in 1991, making it mandatory to incorporate the manure into the soil either directly or shortly after application. To a large extent, this prevented the emission of ammonia $\left(\mathrm{NH}_{3}\right)$ after the application of animal manure.

Currently, in 2017, application of slurry on grassland is only allowed with:

- injection

- shallow injection

- sod injection

- narrow band application.

Application of slurry at arable land is only allowed with:

- injection

- shallow injection

- sod injection

- narrow band application

- incorporation in one track

Application of solid manure at arable land has to be incorporated in two tracks. At grassland, solid manure may still be applied with surface spreading, because there are no emission poor techniques at grassland to do so.

Application of slurry at grassland is allowed from 16 February until 1 September. Application of solid manure from 1 February until 1 September at sandy and loss soils and at other soils until 16 September (RVO, 2017). On arable land, application of slurry is allowed from 1 February until 1 August and for solid manure on sandy and loss soils until 1 September. Application until 1 September is possible for slurry and solid manure when a green manure crop has been sowed. Application of solid manure at arable land on clay and peat soils is allowed the whole year round (RVO, 2017).

Also in the 1990s, it became mandatory to cover all manure storages.

\section{Housing}

More recently, the introduction of low emission housing for shed animals has been introduced. Since 2013, all farms with shed animals have to reduce the ammonia emission from stables. The emission factors for housing systems that farmers have to use are published in the RAV-list (Regeling Ammoniak en Veehouderij, the Ammonia and Animal Husbandry Regulation). Internal compensation is possible: this means that a part of a farmer's existing housing systems does not have to apply best available techniques (BAT), provided that the farmer compensates for the missed ammonia reduction by applying further techniques than BAT in other housing systems. Internal compensation can only be provided for housing systems in stables established before 1 January 2007. Also, farms that stop farming at 1 January 2020 at the latest may still keep animals in regular housing systems in the meantime. See Table 4.1 for the housing systems in 2015 of the most common animal categories in the Netherlands. 
For new housing systems, the allowed maximum ammonia emission is based on the best available techniques. This maximum may change every two or three years. Since 1 July 2015, new housing systems for the animals in the three cases must have ammonia emissions below the following values: ${ }^{1}$

Period: from first of July 2015 :

- Finishers: $1.5 \mathrm{~kg} \mathrm{NH} 3$ per animal place per year

- Dairy cows: $11.0 \mathrm{~kg} \mathrm{NH}$ per animal place per year

- Broilers: $0.035 \mathrm{~kg} \mathrm{NH}$ per animal place per year

Period before first of July 2015:

- Finishers: $1.6 \mathrm{~kg} \mathrm{NH} 3$ per animal place per year

- Dairy cows: $12.2 \mathrm{~kg} \mathrm{NH}$ per animal place per year

- Broilers: $0.045 \mathrm{~kg} \mathrm{NH}$ per animal place per year

Changes after 31 December 2017:

For dairy cows, the permitted limits will be stricter as of 1 January 2018:

- Dairy cows: $8.6 \mathrm{~kg} \mathrm{NH} 3$ per animal place per year

For finishers and broilers kept at IPPC farms, the permitted limits as of 1 January 2020 will be:

- Finishers: $1.1 \mathrm{~kg} \mathrm{NH}$ per animal place per year

- Broilers: $0.024 \mathrm{~kg} \mathrm{NH}$ per animal place per year

For this study, we take into account the permitted limits for new stables from 2018:

- Finishers: $1.5 \mathrm{~kg} \mathrm{NH} 3$ per animal place per year

- Dairy cows: $8.6 \mathrm{~kg} \mathrm{NH}$ per animal place per year

- Broilers: $0.035 \mathrm{~kg} \mathrm{NH}$ per animal place per year

${ }^{1}$ Besluit ammoniakemissie huisvesting veehouderij; http://wetten.overheid.nl/BWBR0036748/2017-01-01\#Bijlage1 and Besluit emissiearme huisvesting. 
Table 4.1 Housing systems in 2015 in The Netherlands of the most common animal categories (\% of livestock) and ammonia emission per animal place

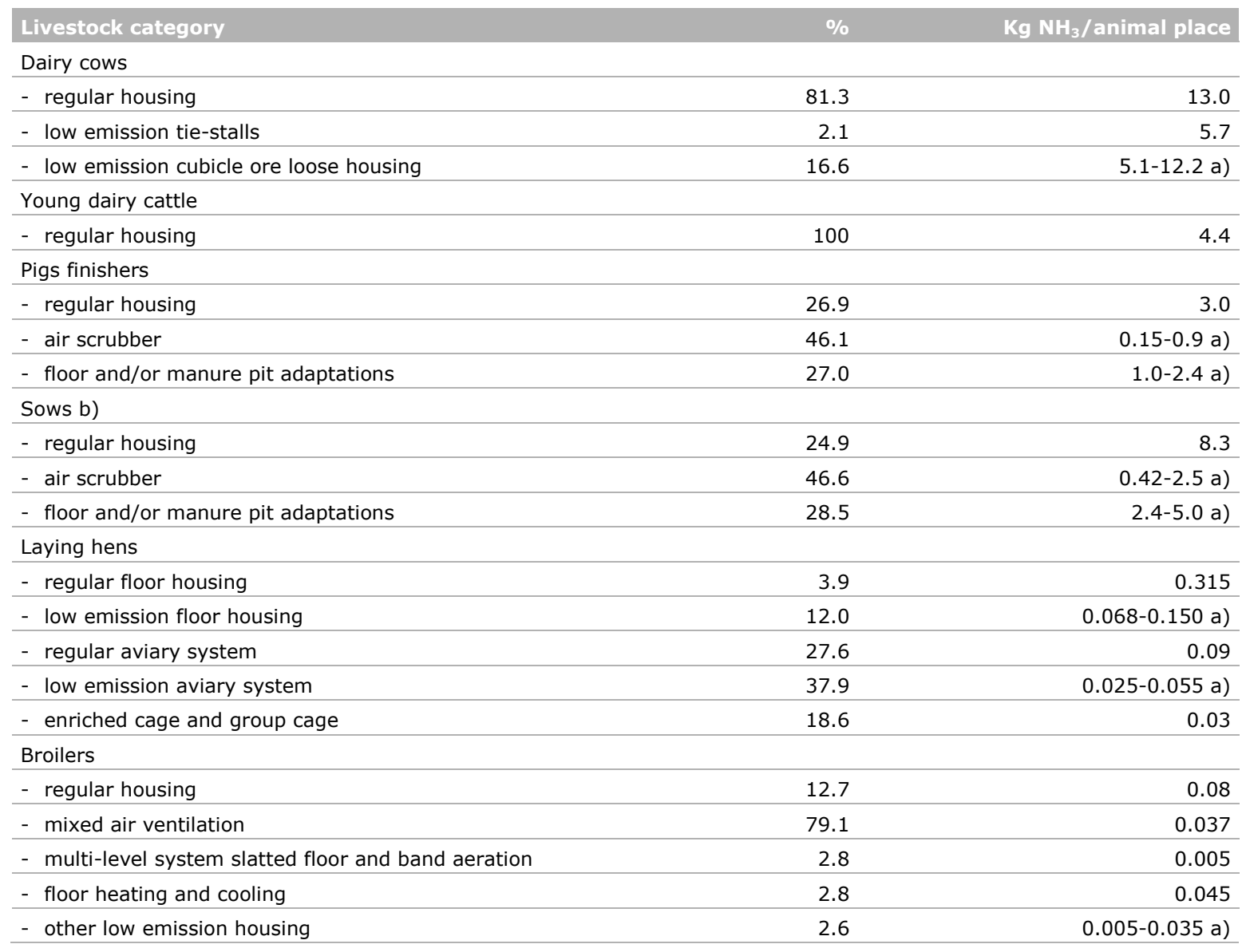

a) Spreading of the possible systems; b) ammonia emission of maternity sows included piglets.

Source: Van Bruggen et al. (2017) and wetten.overheid.nl/BWBBR0013629/2017-04-12.

\section{Location and housing}

On top of the allowed ammonia emission per animal place for newly built or adjusted stables, there are also rules with respect to the location. According to the Ammonia and Animal Husbandry Law (Wet Ammoniak en Veehouderij, WAV), an environmental permit necessary for setting up a livestock farm shall be refused if an animal enclosure belonging to the livestock farm is wholly or partly located in a very vulnerable area, or in a zone of $250 \mathrm{~m}$ around such an area. Similarly, an environmental permit for changing a livestock farm shall be refused if the application relates to an increase in the number of animals in one or more animal categories and an animal accommodation belonging to the livestock sector is wholly or partly located in a very vulnerable area, or in a zone of $250 \mathrm{~m}$ around such an area. Naturally, nitrogen-sensitive Natura 2000-habitats can be characterised as vulnerable areas.

\subsubsection{Integrated Approach to Nitrogen (PAS)}

Under the Integrated Approach to Nitrogen ('Progammatische Aanpak Stikstof', PAS), government authorities and social partners collaborate in order to reduce nitrogen emissions. The PAS will ensure that the objectives of European nature policy are being achieved, while creating the necessary room for economic development (De Heer et al., 2017).

For a densely populated country such as the Netherlands, it is quite a challenge to strike a balance between resilient nature and having a healthy economy. The national government and provincial authorities provide entrepreneurs with some room to manoeuvre, because they are important for the economy. At the same time, economic activities need to fit the carrying capacity of nature, as the economy and nature are in a mutually dependent relationship (Aerius, 2017). ${ }^{2}$

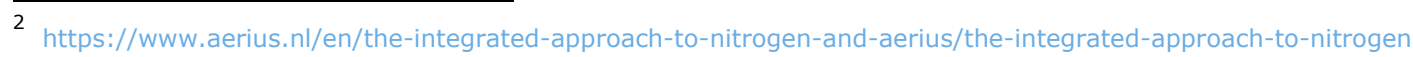


The conservation goal of the PAS is to avoid (further) deterioration of the conservation status of protected habitats in the short term (cf. Habitats Directive art. 6.2), and to contribute to achieving a favourable conservation status in the long term (cf. Habitats Directive art. 6.1). To achieve this goal, two types of measures are taken: generic source measures to reduce nitrogen emissions and ecological restoration measures in Natura 2000 areas (De Heer et al., 2017).

The source measures include implementation of the existing Dutch and European policies on nitrogen. These policies mainly focus on the sectors of agriculture, industry and traffic and transport, targeting emissions of both ammonia $\left(\mathrm{NH}_{3}\right)$ and nitrogenoxides (NOx). Furthermore, especially for the PAS, an additional package with generic agricultural measures has been agreed with the agricultural sector (Ministry of Economic Affairs \& Ministry of Infrastructure and the Environment 2015a; Ministry of Economic Affairs, LTO, Netherlands, NZO, Nevedi, NMV, NVP, NVV and CUMELA Netherlands, 2014). This package involves measures on animal housing (e.g. gas scrubbers), feed and management, and manure application techniques. These measures together should further reduce agricultural emissions, at least $10 \mathrm{kt}$ by 2030, compared to the situation of 2013 (-9\%) (De Heer et al., 2017).

Ecological restoration within the framework of the PAS focuses on the 118 Natura 2000 areas in the Netherlands that contain nitrogen-sensitive habitats. These habitats are defined as habitats with a critical load of less than 2,400 mol/ha/year (33,6 kg N/ha) (Van Dobben, Bobbink, Bal, \& Van Hinsberg, 2014). For nature areas in the Netherlands that do not contain nitrogen-sensitive habitats, high levels of nitrogen deposition are no problem. Restoration may involve measures to remove nitrogen from ecosystems, such as removing topsoil layers (sodding). It can also involve more generic measures to make ecosystems more resilient against the effects of nitrogen, such as hydrological measures. The PAS contains 69 restoration strategies, each containing a package of measures (Jansen et al., 2014; Smits and Bal, 2014; Smits et al., 2014). For the authorities concerned, implementation of the measures is a statutory requirement (De Heer et al., 2017).

North-Brabant and Limburg, two provinces in the south of the Netherlands, hold many livestock farms, which are the primary regional source of nitrogen emissions. Both provinces have stipulated that livestock farms that want to expand, must meet lower (stricter) nitrogen emission standards than what is required nationally. Furthermore, all provinces agreed upon setting provincial rules for the allocation of room for development, on top of the national rules. For example, rules regarding the deadline for a project to start after a permit/license is granted or the maximum percentage a farm/holding may expand. Additionally, provinces may set additional policy rules.

To ensure that agricultural emissions are reduced by at least 10,000 tonnes by 2030 , Dutch government has established more stringent rules regarding the use of fertilisers ('Besluit gebruik meststoffen') and animal housing ('Besluit ammoniakemissie huisvesting veehouderij' and 'Besluit emissiearme huisvesting'). Moreover, the government has implemented several incentive arrangements to achieve this target. A stringent rule is that from the 1 of January 2018 it is not allowed anymore to applicate manure with the drag foot. In addition, the maximum ammonia emission for newly built stables will be stricter as from 1 January 2018 and 1 January 2020 (See Section 4.1.1).

\subsubsection{The principles of room for deposition and room for economic development}

Room for deposition is the quantity of nitrogen deposition that is available for economic growth. A considerable part of the room for deposition is reserved for projects and activities that need a permit; this is called room for development. The remainder of the room for deposition is reserved for projects and activities that are exempted from compulsory licensing: autonomous growth, such as a road traffic increase, and initiatives causing less than $1 \mathrm{~mol}$ nitrogen deposition per hectare per year $(0.014 \mathrm{~kg} \mathrm{~N} / \mathrm{ha})$ in PAS areas.

Through cleaner combustion engines, existing policies and supplementary agricultural policy regarding PAS, nitrogen deposition will continue to decline in the coming years. In addition, measures in the PAS areas will make nature less vulnerable to nitrogen. This leads to room for deposition. 
Room for deposition is established and allocated per PAS area at the hectare level, based on so-called site analyses. For a site analysis, the calculation instrument AERIUS is used to calculate the potential room for deposition based on the expected decrease in nitrogen deposition. Moreover, the ecological restoration measures to be taken are described in the analysis. It is important to stress that room for development is only available if one key prerequisite is met: the combination of a decrease in nitrogen deposition and the implementation of restoration measures must actually ensure that habitats will not deteriorate further, so that eventually nature goals are being achieved. Experienced ecologists have ruled for all 118 areas that the combination of nitrogen deposition decrease, restoration measures and regular nature conservation is expected not to jeopardise the nature objectives of the area. This means that the responsible administrators can make room for development available. Room for development is set for a period of six years.

The AERIUS calculation tool is one of the cornerstones of the PAS. It calculates the level of nitrogen deposition in Natura 2000 areas, caused by projects and development plans. AERIUS supports the issuing of permits for economic activities that involve the emission of nitrogen, and monitors whether the total nitrogen burden continues to decline. In addition, AERIUS also facilitates spatial planning in relation to nitrogen. AERIUS may be used for calculations for all nitrogen-sensitive Natura 2000 areas and all nitrogen-emitting sectors (agriculture, industry, and traffic \& transport) (Aerius, 2017). ${ }^{3}$

AERIUS calculates which part of the total room for deposition should be reserved for autonomous growth and for initiatives with limited nitrogen deposition. The remaining room for deposition is the available room for development for all projects and activities with a permit obligation. The PAS provides sufficient room for development for economic growth of $2.5 \%$ per year, taking into account differences in expected growth between sectors and regions. Based on recent economic growth figures, the growth is actually expected to be lower. If there is no room for development in a certain area, permits can no longer be issued for activities that cause nitrogen deposition in that area. Incidentally, additional room for deposition can be created by implementing additional source measures.

Room for development must be requested for all new activities that cause a nitrogen deposition on a nitrogen-sensitive habitat type of at least $1 \mathrm{~mol}$ per hectare per year. Sometimes, one activity can cause nitrogen deposition in several Natura 2000 areas at the same time. Room for development can be granted, if it is available and if the application complies with the provincial policies.

Room for development is made available at different moments in time. In principle, applications are processed in order of entry. Some provinces have determined that projects or activities must start within a specified period after licensing. It is not possible to issue more room for development than there is available.

\subsubsection{Room for development for agriculture}

In the Agreement on Generic Measures in Agriculture ('Overeenkomst generieke maatregelen landbouw'), agreements are made to achieve an additional net decrease of nitrogen emissions in 2030 of 10,000 tonnes of ammonia compared to 2013 (reference date is 1 January 2014) (See Ministry of Economic Affairs et al., 2014). To establish this decrease in nitrogen emissions, both stable, feed and management measures are taken. Stable measures include air scrubbers, partially slatted floors, heaters and other ways to dry manure. Feed and management measures include decreasing the urea content of milk, promoting pasture grazing, reducing the protein content of the animal feed, and using air-filled balls as a floating cover for manure storage facilities. It has been agreed that, on average, $56 \%$ of the decrease in the 10,000 tonnes of ammonia emissions will be made available to agriculture again in the form of room for development.

3 https://www.aerius.nl/en/the-integrated-approach-to-nitrogen-and-aerius 


\subsubsection{Calculations of nitrogen deposition impact}

The calculations of the impact of nitrogen deposition are illustrated by an example. Take a dairy farm with 220 dairy cows, 4 meat calves and 180 young cattle. The dairy cows, the meat calves and the young cattle are all housed in conventional stables. This farm has an ammonia emission of 3,666 kg $\mathrm{NH}_{3}$ per year. The online calculation tool Aerius calculates the nitrogen deposition of this farm based on the weight, height and heat content of the ammonia emission, and the distance from the source (Aerius, 2017). In this example, the nitrogen deposition at $1 \mathrm{~km}$ of the farm will be $26 \mathrm{~mol} / \mathrm{ha} / \mathrm{year}$ $(0.4 \mathrm{~kg} \mathrm{~N} / \mathrm{ha})$. At $8 \mathrm{~km}$, the nitrogen deposition will be $1 \mathrm{~mol} / \mathrm{ha} / \mathrm{year}$. Note that this calculation is made in Aerius, based on a set of (default) values and assumptions. In practice, results may vary.

Aerius determines the impact of a project, for example farm expansion, on all nature areas. Obviously, only the impacts on nitrogen sensitive Natura 2000 areas are relevant, for other nature areas are not affected by (high levels of) nitrogen. Aerius calculates the nitrogen deposition per hectare for all relevant nature hectares and gives the following output on the scale of the nature area (Aerius, 2017):

- What is the highest nitrogen deposition (mol/ha/year)?

- Does this deposition exceed the critical load (nitrogen-sensitive habitats have a critical load of less than $2,400 \mathrm{~mol} / \mathrm{ha} /$ year)?

- What is the highest required room for development (mol/ha/year)?

- Is this room for development available?

\subsubsection{Allocation of room for deposition}

The room for deposition is all room available for economic development. The room for deposition is set for a period of six years. One can distinguish between projects and actions that are not subject to permission and projects that require a permit (Figure 4.1). The first category consists of autonomous developments, such as an increase of population or road traffic, and from projects that cause less than a limit value in a Natura 2000 area. This limit value is set to reduce the burden for entrepreneurs as much as possible (PAS, 2017). So if the deposition that is expected to result from a new or expanded economic activity will be lower than the limit value, a permit is not required and the initiator only needs to notify the competent authorities (Ministry of Economic Affairs, 2015a). The limit value is basically $1 \mathrm{~mol} / \mathrm{ha} /$ year, but will be lowered to $0.05 \mathrm{~mol} / \mathrm{ha} /$ year after $95 \%$ of the reservation for the notifications is used. At the moment, many of the nitrogen sensitive nature areas have a limit value of $0.05 \mathrm{~mol} / \mathrm{ha} /$ year (Figure 4.2). The second category of activities is divided into priority projects (segment 1, Figure 4.1) and other projects and operations (segment 2, Figure 4.1). Priority projects have been identified by the government or the provinces as projects of national or provincial social importance. The distribution of the room for deposition over the four parts is an administrative choice of the State and provinces (PAS, 2017). 


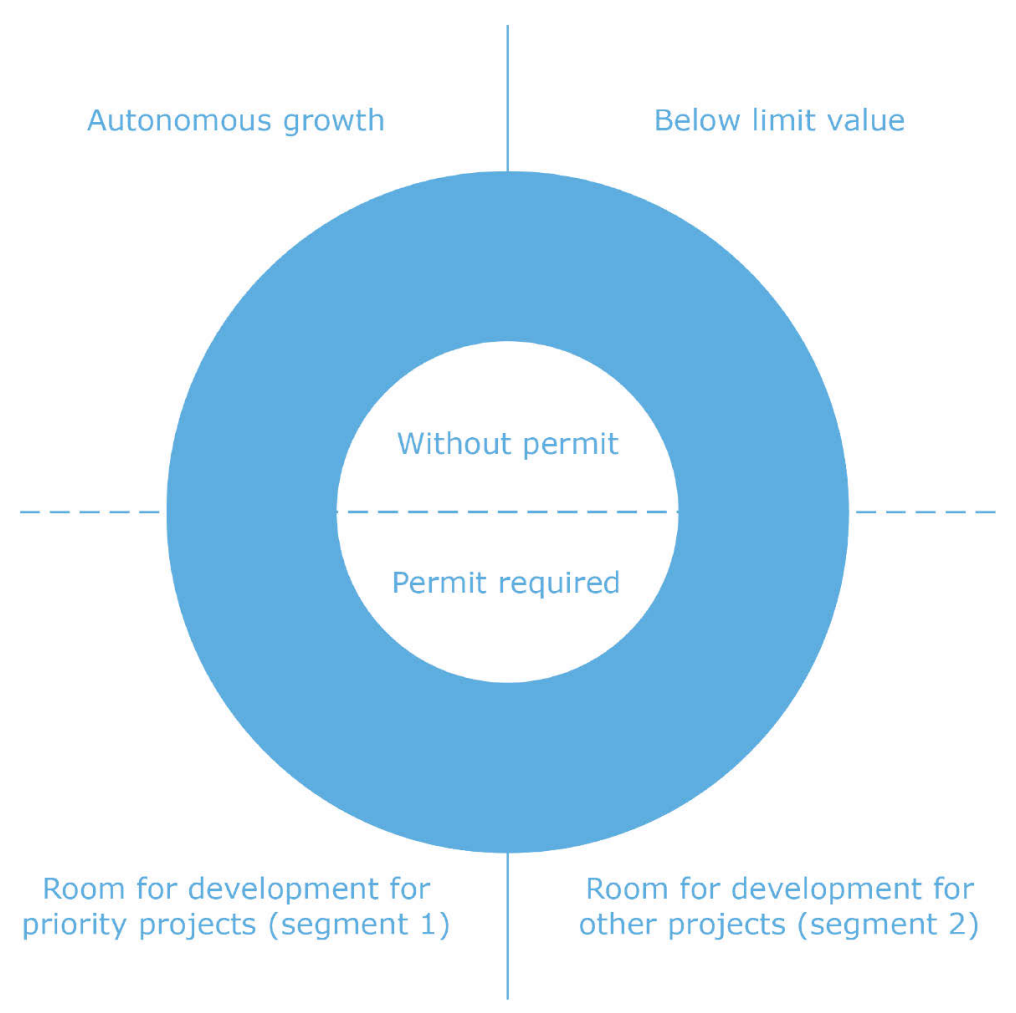

Figure 4.1 Allocation of room for deposition. Based on PAS (2017)

The twelve Dutch provinces are responsible for rule-making regarding the allocation of room for development. Provided that there is enough room for development available, a permit may be issued for projects and operations that fall into segment 2 (Figure 4.1, other projects). In Overijssel, the following policy rules apply (Provincie Overijssel, 2015):

- the deposition does not exceed the maximum of $3 \mathrm{~mol} / \mathrm{ha} / \mathrm{year}$

- if the permit is issued, the project must be realised within two years after it has been granted

- first come, first serve; in other words, the order of receipt of a complete and acceptable application is valid (when arriving by mail, validity time is noon).

At the moment, enough room for development is available in Overijssel to issue permits for projects that fall into segment 2. In some regions in the Netherlands, for example in the province of Friesland, all room for development has already been issued and new applications are not accepted in the coming years. Please note that farmers in Overijssel could also have an impact on nitrogen-sensitive Natura 2000 areas in Friesland, which means that farms in Overijssel also could be hindered when they cause too much deposition in nature areas which are located in the province Friesland. This means that these farms in Overijssel might not be able to obtain room for development as well. 


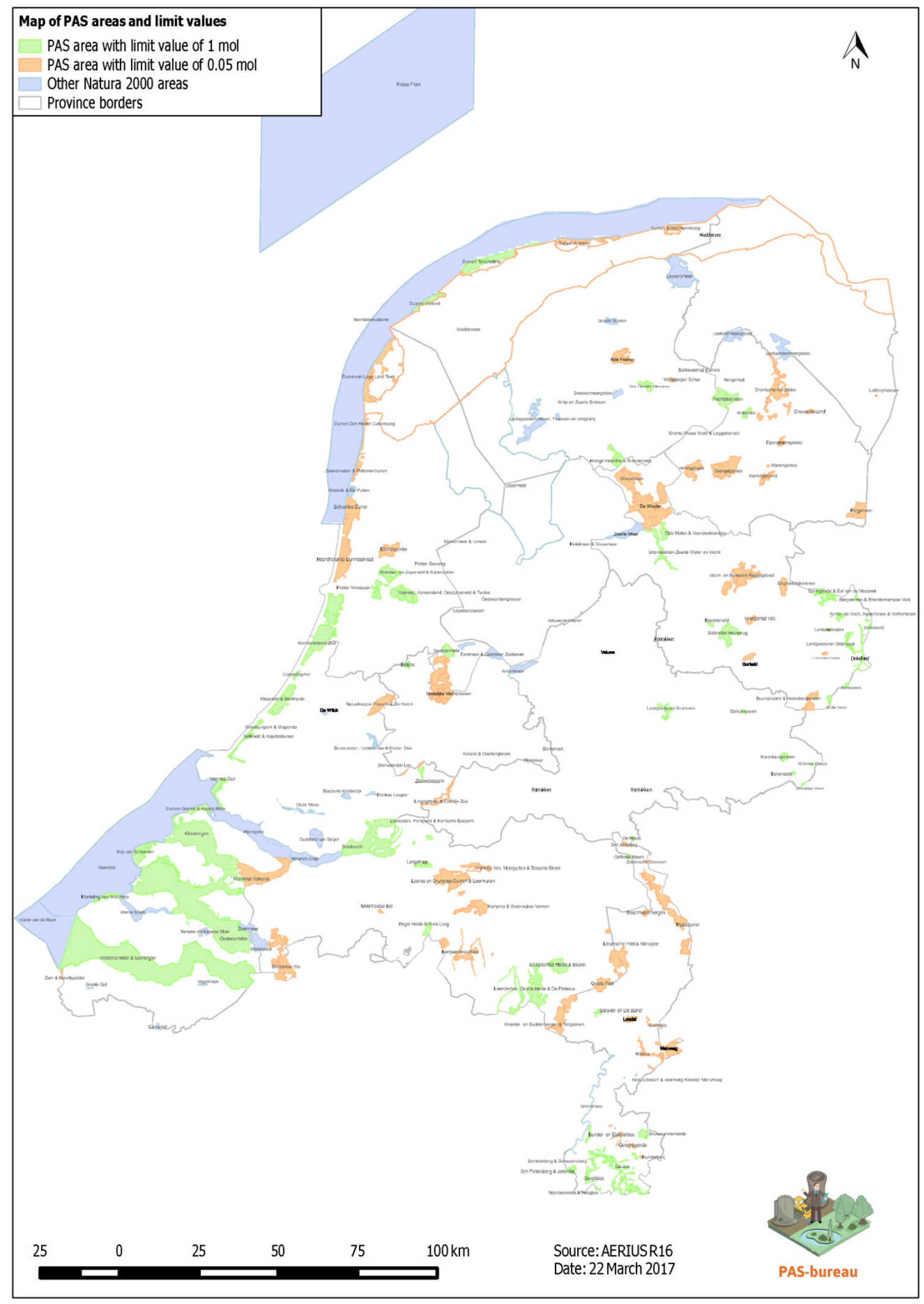

Figure 4.2 Map of PAS-areas and limit values 


\subsubsection{Monitoring and adjustments}

So what happens if it turns out that the deposition has not been reduced sufficiently and / or that nature has deteriorated? If the results of the monitoring programs show that the deposition reduction is lagging behind expectations or if nature quality improves insufficiently, adjustments may be considered. If nature is deteriorating, at first the cause for this deterioration will be investigated. If the cause has to do with the level of nitrogen deposition or the effectiveness of recovery measures, adjustments are due. Adjustments can be, for example, modifying, replacing or adding recovery and resource measures. Also, the availability of room for development for activities that cause nitrogen deposition in the Natura 2000 area concerned (temporarily) may be limited.

\subsubsection{Favourable conservation status and critical loads}

One might argue that a favourable conservation status means that there should be no critical load exceedances for nitrogen, and that this should be the objective of the PAS (De Heer et al., 2017). This point of view is based on the definition of a critical load, which is 'the quantitative estimate of an exposure to one or more pollutants below which significant harmful effects on specified sensitive elements of the environment are not expected to occur according to present knowledge' (Nilsson and Grennfelt, 1988). In the Environmental Impact Assessment (EIA) of the PAS, the following alternatives to the PAS are taken into account (Ministry of Economic Affairs \& Ministry if Infrastructure and the

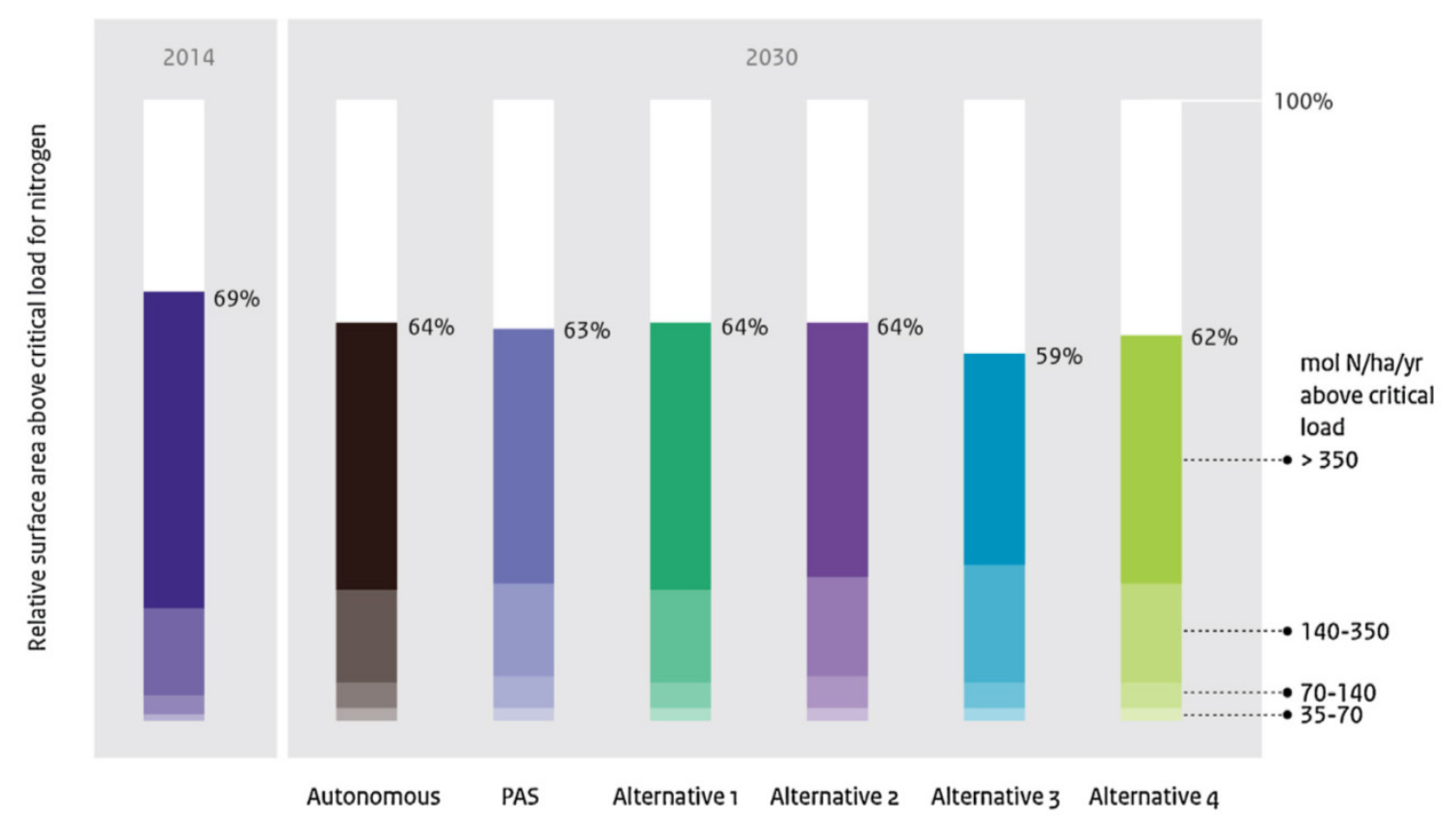

Figure 4.3 Exceedances of the critical load in nitrogen-sensitive habitat types and habitats of protected species in the PAS areas, for 2014 and 2030, under an autonomous scenario, the PAS and four alternatives to the PAS. Bars indicate the percentage of the total area

Source: De Heer et al. (2017); modified from the Environmental Impact Assessment (Ministry of Economic Affairs \& Ministry of Infrastructure and the Environment, 2015b).

Ministry of Infrastructure and the Environment, 2015b):

- Autonomous development

- Alternative 1: Less emission reduction by agriculture sector (5,000 tonnes instead of 10,000 tonnes)

- Alternative 2: Less deposition room made available (30\% instead of $50 \%$ )

- Alternative 3: A considerable extra national emission reduction by extra measures

- Alternative 4: A considerable extra local emission reduction by extra local measures. 
Looking at these alternatives, achieving nitrogen levels below the critical load in all habitats and areas will be very difficult, even by the year 2030 (Figure 4.3: De Heer et al., 2017).

Therefore, setting the critical load as an objective was considered not very realistic and politically not feasible. Early 2016, the Council of State ruled that 'the exceedance of the critical deposition load can be no more than an indication that deterioration of a habitat is not unlikely' (Council of State, 2016). This supports the idea that the critical load does not need to be the target. Still, compared to the autonomous situation, a considerable reduction of nitrogen deposition is possible, as shown in the EIA (Environmental Impact Assessment) by the PAS and alternatives 2 and 4 (the latter also including suspension of economic activities close to Natura 2000 areas) (Figure 4.4). Alternative 3 shows that taking even more emission-reducing measures would result in a more positive effect on the decrease in nitrogen deposition (Figure 4.3) and, thus, on the nature objectives than is achieved under the PAS. However, these alternatives would have met with more resistance from economic stakeholders and would politically not have been feasible. For the PAS, the choice was made for a balance between benefits to nature and burden to society (De Heer et al., 2017). To achieve the conservation objectives, the strategy was chosen to combine reduction in deposition with ecological restoration measures (Ministry of Economic Affairs \& Ministry of Infrastructure and the Environment, 2015a).

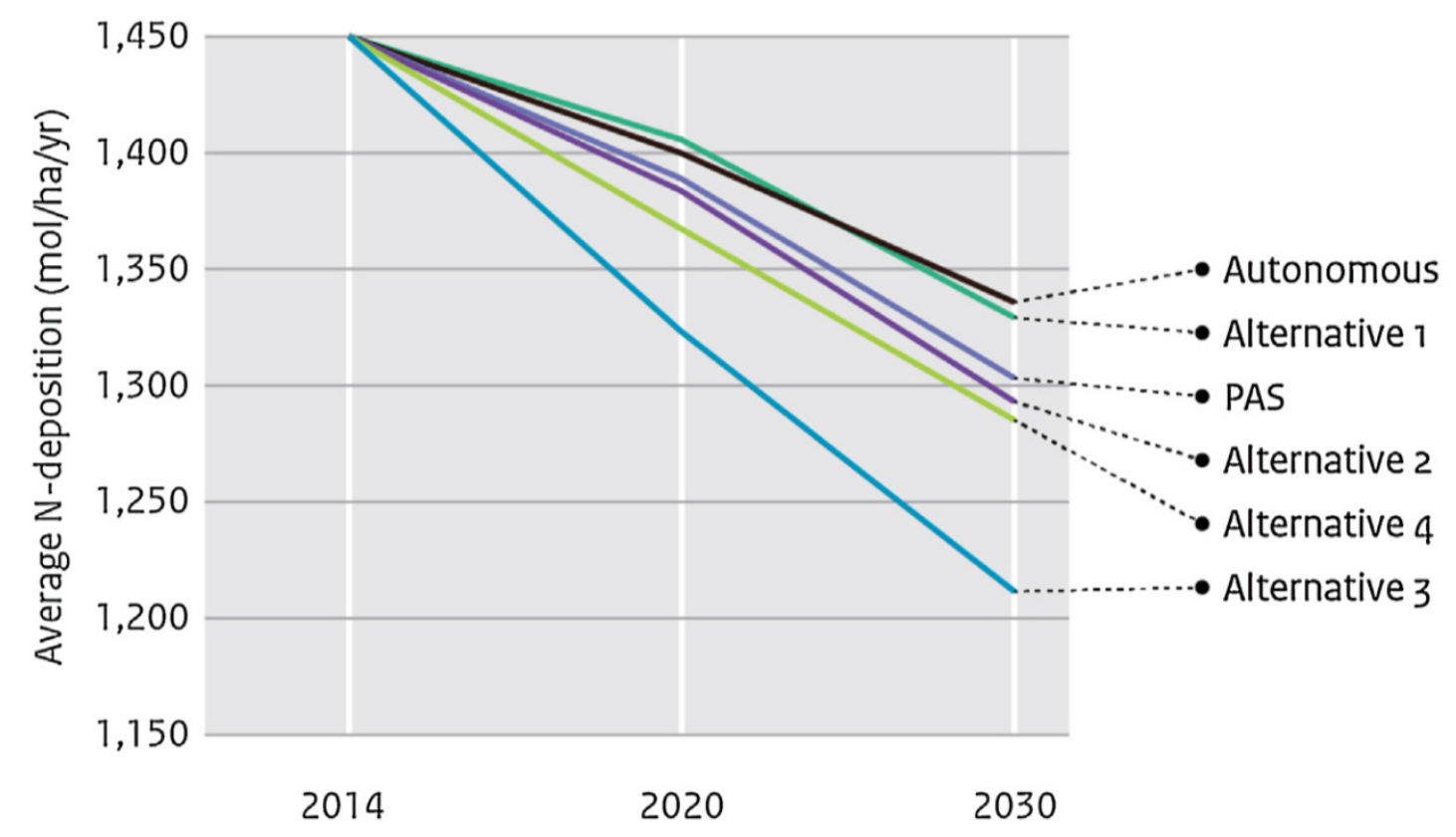

Figure 4.4 Trend in average nitrogen deposition in PAS areas Source: Environmental Impact Assessment (Ministry of Economic Affairs \& Ministry of Infrastructure and the Environment, 2015b).

\subsection{Denmark}

\subsubsection{Regular ammonia-emission regulation}

When a farmer wants to establish, expand, or rebuild a livestock installation, a permit is needed. According to the rules from before 1 August 2017, medium and large farms (over 75 LSU) would have to apply BAT technology and 30\% emission reduction for the new livestock installation compared with the 2005/2006 emission from the reference technology for that given type of livestock (See appendix 3). Small farms (<75 LSU) do not have to apply BAT technologies.

With respect to storage, the requirement is that a solid cover is present. This can be a natural cover (a crust), which needs to cover the whole slurry tank. In other cases the application of for example straw 
is required to ensure that the cover becomes full in a couple of days. In some cases (e.g. pig farms), a solid cover in the form of a tent or a floating lid is required as the natural cover is not sufficient. A logbook on the conditions of the cover has to be kept on the farm and notes have to be taken every month. It has to be reported whether a broken natural cover recovers. If the Danish authorities decide that the cover is insufficient for the second time, a farmer is forced to change to a solid cover. The storage facility is examined every 10 years (Jacobson et al., 2017).

With respect to application the requirement is that slurry applied in the spring before a crop is injected otherwise trailing hoses can be used. Injection is required also on grass fields (feed and seed), but e.g. not on winter wheat or winter oil seed rape. Broad spreading is not allowed. Only very limited application from harvest to November (selected crops and conditions) is permitted and no application from November to 15 February is allowed. Technologies (e.g. acidification in the stables) (see technology list) can be used so that using a trailing hose is allowed instead of injection.

From 1 August 2017 the permit application is considered in regards to the general ammonia reduction requirements and reductions by the use for housing systems of the best available technology (BAT) for farms emitting more than $750 \mathrm{~kg} \mathrm{NH}-\mathrm{N}$ /year (BAT requirements; Jacobson et al., 2017). For the existence housing systems in 2004 and 2012 in Denmark see Table 4.2. According to the comments to the legal part of the law the limit of $750 \mathrm{~kg} \mathrm{NH}-\mathrm{N} \mathrm{pr}$. year is roughly equivalent to the limit imposed in the present $\S 11$ - regulation (over 75 LSU) (see Appendix 4b). The limits stated here are always for the total production after the expansion and not for the size of the production before expansion. There are in effect no regulations which focus on the emissions from existing farms which do not change their size of production, but over time most farms will have applied to expand the farm. It is assumed that farms will not divide their activities into smaller units to avoid regulation requirements.

Before 1 August 2017, the BAT requirement for the production started at 75 LSU (see Appendix 4a) and after that date, it started at an emission level of $750 \mathrm{~kg} \mathrm{NH}-\mathrm{N}$.

The 30\% reduction requirement compared to the 2005/2006 emission level (based on the reference technology) is no longer required even when the production is over $250 \mathrm{AU}$ or $3,500 \mathrm{~kg} \mathrm{NH}-\mathrm{N}_{\text {per }}$ year. The idea is that the BAT requirement per animal place or $\mathrm{m}^{2}$ of stable in the future will give the same emission level or lower than a requirement based on the 2005/06 reference technology minus $30 \%$, why the requirement is not needed anymore. An emission of 3,500 $\mathrm{kg} \mathrm{NH}_{3}-\mathrm{N}_{\text {per year is }}$ assumed to be equivalent to 750 places for sows or 2,000 places for finishers (from $30 \mathrm{~kg}$ ) or 40,000 places for broilers.

The BAT requirements refer to the best available technology (BAT) which the farmer necessarily needs to include in the project plan in order to get an approval of the project. The BAT technologies are found on the Technology list produced by the Environmental Agency and the technologies have both a certified effect on $\mathrm{NH}_{3}$ emissions and the technology is perceived to have an affordable level of costs (Jacobsen et al., 2017). Technologies costing more than DKK 100 per $\mathrm{kg} \mathrm{NH}_{3}-\mathrm{N}$ or $1 \%$ of the total production costs are considered too expensive are therefore not included (Jacobsen et al, 2017) and for finishers a level of DKK $8(€ 1,1)$ per finisher has been set as the cut off level. As the cost per unit decreases with size the BAT emission levels have been set so that the allowed emission levels are lower for larger than smaller farms. In doing so the actual costs per farm is roughly the same across differing farm sizes. 
Table 4.2 The Housing systems in Denmark in 2004 and 2012 for the of the most common animal categories (\% of livestock)

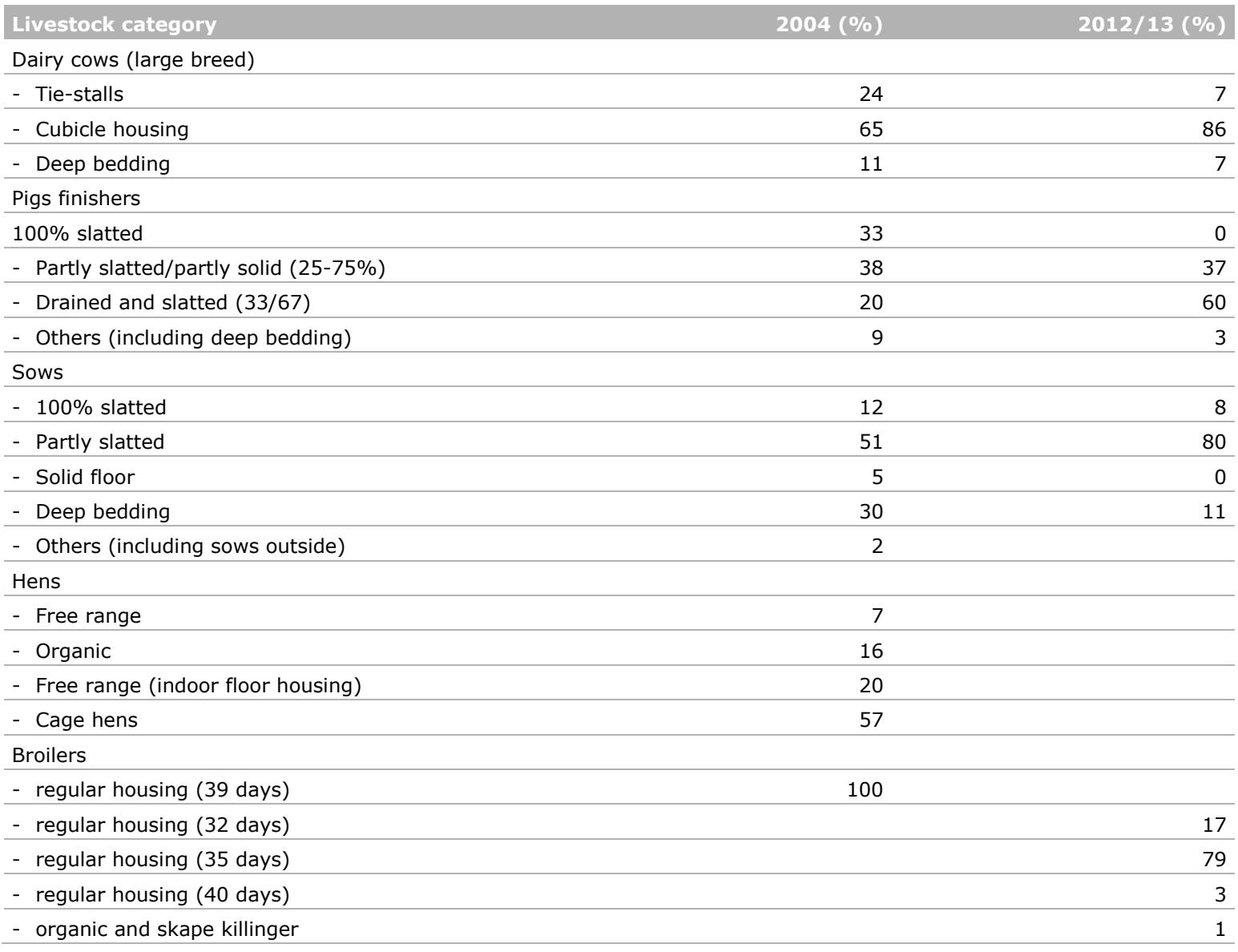

Source: Jacobsen et al. (2017).

\subsubsection{The allowed emissions now and in future}

The results in the report are based on the old regulation system. This section provides a short description of the future regulation setup and some of the implications.

The implication of the new system for production permits is that the emission in the future will per unit of space in the stables and not as today per unit of animal. The production area is defined 'as the area where animals more or less have access to all the time and so would deposit manure even if manure is not deposited there' (Jacobsen et al., 2017). In the change it is also the intention to reduce the number of levels for each type of animal. The corresponding values for the case farms are included in Table 4.3.

Table 4.3 Conversion from stable emission per animal to emission per $\mathrm{m}^{2}$ and per place

\begin{tabular}{|c|c|c|c|}
\hline Description & $\begin{array}{l}\text { Emission } 2017 \\
\text { (kg N/animal) }\end{array}$ & $\begin{array}{r}\text { Emission } \\
\left(\mathrm{NH}_{3}-\mathrm{N} / \mathrm{m}^{2}\right)\end{array}$ & $\begin{array}{r}\text { Emission } \\
\left(\mathrm{NH}_{3}-\mathrm{N} / \text { animal place }\right)\end{array}$ \\
\hline \multicolumn{4}{|l|}{ Finishers } \\
\hline $34 \%$ drained and $66 \%$ slatted floor & 0.405 & 2.3 & 1.49 \\
\hline \multicolumn{4}{|l|}{ Dairy cows } \\
\hline - Cubicles with slatted floor & 10.61 & 1.34 & 10.705 \\
\hline \multicolumn{4}{|l|}{ Broilers } \\
\hline - Loose housing & 0.0046 & 0.74 & 0.04 \\
\hline
\end{tabular}

Source: Jacobsen et al. (2017). 
A new set of limits for emissions per $\mathrm{m}^{2}$ and animal place are established. Again they might not be a direct translation from emission per animal, but the overall principle is that the emission requirements are the same. Based on Table 4.4 this seems to be the case, although it can be seen that the reduction requirement compared for the different types of livestock and levels are not all the same.

Table 4.4 Emission requirements in previous and new regulation in 2017

\begin{tabular}{|c|c|c|c|c|}
\hline Description & $\begin{array}{r}\text { Previous } \\
\text { (kg N/animal) }\end{array}$ & $\begin{array}{r}\text { New } \\
\left(\mathrm{NH}_{3}-\mathrm{N} / \mathrm{m}^{2}\right)\end{array}$ & $\begin{array}{r}\text { Required } \\
\left(\mathrm{NH}_{3}-\mathrm{N} / \mathrm{m}^{2}\right)\end{array}$ & $\begin{array}{r}\text { Required } \\
\left(\mathrm{NH}_{3}-\mathrm{N} / \mathrm{m}^{2}\right)\end{array}$ \\
\hline Finishers & & & $>75$ and $<250$ LSU a) & $>750$ LSU a) \\
\hline \multicolumn{5}{|l|}{ Dairy cows } \\
\hline - Cubicles with slatted floor & 10.61 & 1.34 & 0.67 & 0.67 \\
\hline - Loose housing & 0.0046 & 0.74 & 0.57 & 0.57 \\
\hline
\end{tabular}

a) Emission requirements from 250 to 750 LSU for finishers are linear.

Source: Jacobson et al. (2017).

\subsubsection{Ammonia-emission regulation near nature}

The further emission requirements related to Natura 2000 depend on the habitat and the number of other emissions (neighbours). As noted in Figure 4.5 there are 3 categories of 'ammonia-sensitive' habitats, where the Category 1 nature can tolerate the lowest emissions. Only Category 1 nature is located inside Natura 2000 sites. The calculations for the case farms are mainly related to the Category 1 requirements.

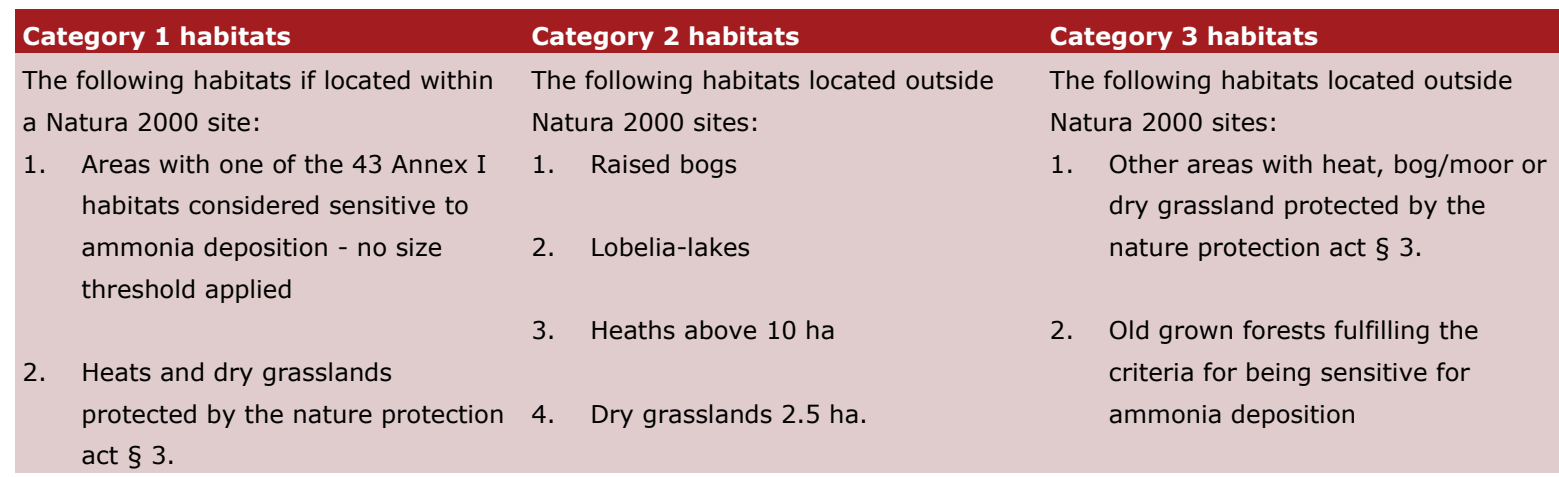

Figure 4.5 Definitions of the different categories of habitat Source: Jacobsen et al. (2017).

Table 4.5 shows the maximum total ammonia deposition (stable and storage) in the area near the farm under consideration for an approval to expand or rebuild. The allowed ammonia deposition is dependent on whether there is any protected nature near the farm and the existence of neighbouring livestock farms. The lowest total nitrogen deposition from a farm is permitted in Category 1 nature areas, which are defined as ammonia-sensitive nature types within Natura 2000 areas. In the case of proximity to Natura 2000 sites, the presence of neighbouring animal farms further decreases the amounts of total allowable nitrogen deposition and will thus reduce the allowed ammonia emissions from the farm in question.

The background for the levels were that the total deposition should not be above $1 \mathrm{~kg} \mathrm{~N} / \mathrm{ha} / \mathrm{year}$. To be on the safe side the level of 0.7 was introduced by the Agency and at the same time it was included that if one livestock neighbour caused a deposition of $0.3 \mathrm{~kg} \mathrm{~N}$ per ha per year this farm could only have a deposition of $0,4 \mathrm{~kg} \mathrm{~N}$ per ha per year. The level was further reduced with two neighbours to ensure that the $1,0 \mathrm{~kg} \mathrm{~N}$ per ha per year level would not be exceeded. 
For Category 3 nature the limit is the additional emission allowed from the farm based on the expansion of the farm. In the assessment made by the municipality they look at the baseline deposition and the additional deposition from the farm. It could be noted that the limits in relation to Category 1 and 2 nature is the total farm emission. In the case of Category 3 nature, the additional deposition compared to the situation before changes on the farm and requirements cannot be very small (<1 kg N ha per year), which could prevent an expansion. The municipality looks at the critical load and the existing base load including the emission from the initial farm. The allowed additional deposition could be $2-3 \mathrm{~kg} \mathrm{NH}$ per ha, or even around 15-20 kg for some bogs. It all depends on the nature area's critical load.

Table 4.5 Types of ammonia-sensitive nature and allowed maximum deposition of nitrogen from stables, storage and application of manure allowed from farm ( $\mathrm{kg} \mathrm{N} / \mathrm{ha} / \mathrm{year}$ ) in relation with number of neighbours

\begin{tabular}{|c|c|c|c|}
\hline Nature type & No neighbours & 1 neighbour & 1 neighbour \\
\hline Natura 2000 area & 0.7 & 0.4 & 0.2 \\
\hline $\begin{array}{l}\text { Outside Natura } 2000>2.5 \text { ha sensitive } \\
\text { grassland or }>10 \text { ha heaths }\end{array}$ & 1 & 1 & 1 \\
\hline $\begin{array}{l}\text { Outside Natura } 2000<2.5 \text { ha sensitive } \\
\text { grassland a) or dry grassland, heaths } \\
\text { and bog }>0.25 \text { ha }\end{array}$ & $=>1 \mathrm{~kg}$ & $=>1 \mathrm{~kg}$ & $=>1 \mathrm{~kg}$ \\
\hline
\end{tabular}

a) Parenthesis implies that decision on threshold depends on the local situation; Additional deposition from farm compared to the baseline without the change in livestock production ( $\mathrm{kg} \mathrm{N} / \mathrm{ha} /$ year).

Source: Jacobsen et al. (2017).

As shown, the number of neighbouring livestock farms influence the allowed emission based on the so-called accumulation approach. The livestock stables or installations included in the calculation depend on the size of the farms. The larger the farm, the larger distance is included and so for neighbouring farms just over 15 LSU the distance around the farm is only $200 \mathrm{~m}$, whereas for farms with over 150 LSU the distance is between 500 and 1,000 m. For farms with over 500 LSU the distance is based on a more detailed calculation.

The larger distance used for larger livestock farm is to reflect that larger livestock farms will have an impact on the total ammonia deposition in a larger area. The neighbour's emission is not directly included in the calculation for the farm applying, but the limits are lower if there is a neighbour as described above. In other words, a neighbour is only included in the calculation if the area around his farm, based on the size of production, intersects the area of the farm that is increasing production.

It could be said that the total deposition from all the farms in an area only indirectly decides the allowed emission levels for the farm increasing the production. The actual total deposition on the nature sites in the area from all the farms in relation to the critical load for the specific nature located near the farm is not a key parameter in Denmark in relation to Category 1 and as the protection is based on a total deposition level for the farm. In the case of Category 3 the municipalities relate the calculated deposition (from the calculation through the computer program which is also used to the calculated depositions on Category 1 and 2) on the specific Category 3 nature types and relate that to the critical load locally, which would typically be between $10-25 \mathrm{~kg} \mathrm{~N} / \mathrm{ha}$.

\subsection{Comparison of the Netherlands with Denmark}

\section{Regular ammonia-emission regulation}

In the Netherlands, all storage of slurry outside the housing must be covered. In Denmark, a solid layer of for example straw will do. As a result, the emission of ammonia from slurry tanks will probably be higher in Denmark than in the Netherlands. 
Both in the Netherlands and Denmark, broad spreading is not allowed anymore. A big difference in application of manure is that in Denmark a trailing hose can still be used, whereas it is not allowed anymore in the Netherlands. This is due to the relatively high ammonia emission of this technique compared with the injection and direct incorporation of manure. Due to this difference in application technique, the ammonia emission from application will probably be higher in Denmark than in the Netherlands.

There is a big difference between Denmark and the Netherlands when it comes to old housing systems for pigs and chickens: in Denmark, there is no regulation about the ammonia emission, whereas in the Netherlands, all farms must reduce the ammonia emission at least with $50 \%$ compared to regular housing. Only farms that stop before 2020 are excused. About $25-30 \%$ of the livestock in Denmark is housed in old housing systems (Jacobsen, 2017).

For newly built housing systems for finishers the allowed emission depends on the farm size in Denmark:

1. No restrictions for very small farms less than 180 animal places ( $<15$ LSU)

2. For small finisher farms between about 180 and 900 animal places ( $>15$ LSU and <75 LSU) it is $2.30 \mathrm{~kg}$ of $\mathrm{NH}_{3}-\mathrm{N}$ per $\mathrm{m}^{2}$ that is $1.5 \mathrm{~kg} \mathrm{NH}_{3}-\mathrm{N}$ per animal place

3. For farms between about 900 and 3,000 animal places (75-250 LSU) it is $1.62 \mathrm{~kg}$ of $\mathrm{NH}_{3}-\mathrm{N} \mathrm{per} \mathrm{m}^{2}$ that is $1.06 \mathrm{~kg} \mathrm{NH}-\mathrm{N}$ per animal place

4. For farms between 3,000 and 9,000 animal places (250-750 LSU) it is linear between 1.62 and $1.06 \mathrm{~kg} \mathrm{NH}_{3}-\mathrm{N}$ per m${ }^{2}$

5. For big farms more than 9,000 animal places ( $>750 \mathrm{LSU}$ ) it is $1.06 \mathrm{~kg}$ of $\mathrm{NH}_{3}-\mathrm{N} \mathrm{per} \mathrm{m}^{2}$ that is $0.69 \mathrm{~kg}$ of $\mathrm{NH}_{3}-\mathrm{N}$ per animal place.

In the Netherlands, for all newly built housing systems (independent of the farm size) the maximum allowed ammonia emission is $1.5 \mathrm{~kg}$ of $\mathrm{NH}_{3}$ per animal place $\left(1.24 \mathrm{~kg} \mathrm{NH}_{3}-\mathrm{N}\right)$. At $0.85 \mathrm{~m}^{2}$ per animal, that is an emission of $1.46 \mathrm{~kg} \mathrm{NH}_{3}-\mathrm{N}$ per $\mathrm{m}^{2}$. In Denmark the middle size farms $(900-4,750$ animal places) may emit more ammonia than in the Netherlands per $\mathrm{m}^{2}$ but for big farms $(>4,750$ animal places) it is the other way round. In Denmark the amount of ammonia emission from a farm between 3,000 and 9,000 animal places declines linearly from 1.62 to 1.06 . When this is converted to the farm size where the ammonia emission rules per $\mathrm{m}^{2}$ in the Netherlands and Denmark are equal, then that results in a farm size of 4,750 animal places.

For cows at middle size and big farms the allowed emissions for newly built housing systems in Denmark are stricter than in the Netherlands. For middle size and large dairy farms (more than $75 \mathrm{LSU}$, about 100 animals) is the maximum emission in Denmark $5.35 \mathrm{~kg} \mathrm{NH}_{3}-\mathrm{N}$ per animal place per year and for small farms (less than $75 \mathrm{LSU}$ ) it is $10.7 \mathrm{~kg} \mathrm{NH}_{3}-\mathrm{N}$ per animal place. In the Netherlands from 2018 it will be $8.6 \mathrm{~kg} \mathrm{NH}(7.1 \mathrm{~kg} \mathrm{NH}-\mathrm{N})$ per animal place per year for all dairy farms.

For broilers however the allowed emissions are stricter in the Netherlands. For broilers, the maximum in 2017 in the Netherlands is $0.035 \mathrm{~kg} \mathrm{NH}_{3}\left(0.029 \mathrm{~kg} \mathrm{NH}_{3}-\mathrm{N}\right)$ per animal place per year for all farms and in Denmark $0.031 \mathrm{~kg}$ for middle size and big farms (>75 LSU; 26,000 animal places) and for small farms ( $<75 \mathrm{LSU}$ ) it is $0.040 \mathrm{~kg} \mathrm{NH}_{3}-\mathrm{N}$ per animal place per year.

\section{Ammonia-emission regulation near nature}

It is difficult to compare both countries in this matter, because the rules are totally different. In the Netherlands, the total deposition of nitrogen is relevant for new initiatives, thus not only ammonia deposition of nitrogen from agriculture. This is not the case in Denmark, which is only concerned with the deposition of nitrogen from ammonia from the agriculture sector.

In the Netherlands, the regulation is only about extra ammonia emission compared to the present situation. In Denmark, the rules are stricter: when a farm is rebuilt or expanded, the allowed ammonia deposition on the habitat nature inside Natura 2000 areas must not exceed a certain level. In most cases this results in the fact that the emission must be lower than in the present situation. 


\section{Netherlands}

When initiatives cause less than $1 \mathrm{~mol}$ of extra nitrogen deposition per ha per year $(0.014 \mathrm{~kg}$ $\mathrm{N} / \mathrm{ha}$ /Year) on nature in the Netherlands, then they may proceed. The legally permitted deposition levels mean that even farms located far from nature sites (for instance $10 \mathrm{~km}$ ) could have a reduction requirement. In addition, there may be room for deposition, then the extra nitrogen deposition may be in most cases $3 \mathrm{~mol}$ per ha per year $(0.042 \mathrm{~kg} \mathrm{~N} / \mathrm{ha} /$ Year). How much room for deposition there is depends on the location and would be decided by the local government. The amount of nitrogen deposition and the room for deposition is calculated with the instrument AERIUS. Which economic activity gets the room for deposition is a decision of the local government in the Netherlands. When there is room for deposition available for agriculture, then a 'first comes, first served' approach applies. This means that for every individual farm the amount of ammonia emission after expanding would be different, it depends from the local situation and the location of the farm to a nature area.

\section{Denmark}

The maximum allowed deposition of nitrogen from a farm on a Natura 2000 area depends on whether there are neighbouring livestock farms. With no neighbour, the maximum is $0,7 \mathrm{~kg} \mathrm{~N} / \mathrm{ha} / \mathrm{year}$ and with more than one neighbour, this is $0.2 \mathrm{~kg} \mathrm{~N} / \mathrm{ha} / \mathrm{year}$. The amount of emission on nature is in Denmark calculated by the Environmental Protection Agency using a computer program. 


\section{Costs of ammonia-reduction measures}

\subsection{The Netherlands}

\subsubsection{General}

In this chapter, the results are presented based on rules that are general for the case farms. There are also rules that are not general and will differ depending on the location of the farm, these are:

1. New initiatives that have an extra ammonia deposition at Natura 2000 areas of at maximum 1 or $0.05 \mathrm{~mol}$ per ha per year $(0.014$ or $0.0007 \mathrm{~kg} \mathrm{~N} / \mathrm{ha} /$ year; depending on the type of nature, see Section 4.6), have no extra restrictions. How much deposition is caused by ammonia emissions at the farm location depends on the distance of the farm to nature and the wind direction, among other factors. Since the local situations of the case farms are not known, it is not possible to calculate the allowed ammonia emission at the farm location of the permitted limits of 1 or 0.05 mol.

2. Due to extra local rules, it is possible that the farm cannot obtain all the room for development it needs. For instance, the province of Overijssel has, as other provinces have, implemented a rule that the room for development a farm can obtain, may at most cause an extra deposition at Natura 2000 areas of $3 \mathrm{~mol}$ per ha per year $(0.042 \mathrm{~kg} \mathrm{~N} / \mathrm{ha} / \mathrm{year})$. Since the local situations of the case farms are not known, it is not possible to calculate the allowed ammonia emissions at the farm location of the maximum of $3 \mathrm{~mol}$.

\subsubsection{Finishers}

Expand the production from 7,200 to 14,400 finishers. Roughly speaking, that is from 2,500 to 5,000 animal places.

The most common Dutch situation of the 2015 housing systems is taken into account. That is, about $70 \%$ of the animals $(1,750$ animal places) are kept in a stable with an air scrubber with an average emission of $0.7 \mathrm{~kg}$ of $\mathrm{NH}_{3}$ per animal place, and 30\% of the animals (750 animal places) is kept traditionally, with an average emission of $3.0 \mathrm{~kg}$ of $\mathrm{NH}_{3}$ per animal place (Van Bruggen et al., 2017). At farm level, that is on average $1.39 \mathrm{~kg}$ of $\mathrm{NH}_{3}$ per animal place ( $70 \%$ of $0.7 \mathrm{~kg}$ and $30 \%$ of $3.0 \mathrm{~kg}$ ). Since it is common in the Netherlands to store all the manure under the stable floor, it is assumed that this is the case for all farms. In the rest of this section, we consider the situation of the ammonia rules of 2018 (see Section 4.1.1).

For this study, two scenarios are considered regarding the availability of room for development:

- There is no room for development available

- There is room for development available for $1.5 \mathrm{~kg}$ of $\mathrm{NH}_{3}$ per animal place.

A farm that has no significant negative impact on nitrogen-sensitive habitats and that wants to expand by 2,500 animal places has to keep these animals in a housing system with a maximum ammonia emission of $1.5 \mathrm{~kg}$ per animal place per year (Appendix 3). The same accounts for a farm that does have a negative influence on nitrogen-sensitive nature areas, but is able to obtain enough room for development to emit $3,750 \mathrm{~kg}$ of $\mathrm{NH}_{3}$ per year (based on availability of room for development; 2,500 animal places $* 1.5 \mathrm{~kg}$ of $\mathrm{NH}_{3}$ per animal place).

A farm that is not able to obtain room for development and that has a total lodge ammonia emission of $3,475 \mathrm{~kg}$ of $\mathrm{NH}_{3}$ (current situation; $1.39 \mathrm{~kg} /$ animal place $* 2,500$ animal places0, cannot increase the total ammonia emission above this $3,475 \mathrm{~kg}$ of $\mathrm{NH}_{3}$ after expanding. The amount of $3,475 \mathrm{~kg}$ of $\mathrm{NH}_{3}$ can only be reached by changing the traditional housing system with 750 animal places for a new low-emission stable with 3,250 places $(750+2,500)$ that emits at most $2,250 \mathrm{~kg}$ of $\mathrm{NH}_{3}$ (existance 
farm situation of 3,475 kg - existance stable with air scrubber which emits $1,225 \mathrm{~kg}$ of $\mathrm{NH}_{3}$ ammonia), that is $0.69 \mathrm{~kg}$ per animal place per year. This is only possible with stables with air scrubbers that reduce the ammonia emission with $75 \%$ or more (Appendix 3 ). A combined air scrubber for a stable with 3.250 finishers costs $€ 10.10$ per pig place more than a traditional stable and $€ 5.10$ more than a stable with cooling (Table 5.1). This means that with no room for development available, the costs for a farmer that expands his farm with 2,500 pigs near one or more Natura 2000 areas are $€ 20,000$ yearly $(750 * 10,1+2,500 * 5,1)$ higher than the costs of a farm that has no significant negative impact on nitrogen-sensitive habitats. With the combined air scrubber (D 3.2.15.3) the ammonia emission is $0.45 \mathrm{~kg}$ of $\mathrm{NH}_{3}$ per animal place per year and 2,668 kg at the farm level. It is expected that a farmer in this situation will decide to build a bigger stable for 5,000 places for the total ammonia emission room of $3,500 \mathrm{~kg} \mathrm{NH}$, or choose for a cheaper stable with more ammonia emission and expand less.

Table 5.1 Extra investment and extra year cost per animal place for four different stables for housing of finishers compared to a traditional stable

\begin{tabular}{|c|c|c|c|c|c|}
\hline Kind of stable & $\begin{array}{l}\text { Stable } \\
\text { number }\end{array}$ & $\begin{array}{l}\text { Number of } \\
\text { finishers }\end{array}$ & $\begin{array}{r}\text { Extra investment } \\
(\mathrm{C}) \mathrm{b})\end{array}$ & $\begin{array}{l}\text { Extra year cost } \\
\text { investment }(\boldsymbol{\varepsilon})\end{array}$ & $\begin{array}{l}\text { Extra year cost } \\
\text { exploitation ( }())\end{array}$ \\
\hline Stable with Cooling & D 3.2.6.1 & 2,500 & 29 & 3.72 & 1.28 \\
\hline Combined air scrubber & D 3.2 .15 .3 & 2,500 & 42 & 6.10 & 4.60 \\
\hline Separated remov. of faeces a) & D 3.3 .16 & 2,500 & - & - & -2.00 \\
\hline
\end{tabular}

a) Rougly estimate by author due to lack of information; b) Total investment traditional stable $€ 430$ per animal place; interest $3.5 \%$; depreciation $4 \%$.

Source: Izak Vermeij, 2017, WUR (Wageningen Livestock Research).

\section{Conclusion}

A finisher farm that has a negative influence on nitrogen-sensitive nature areas and no room for development has $€ 20,000$ higher housing costs yearly when it expands from 2,500 to 5,000 finishers than a farm that has no significant negative impact on nitrogen-sensitive habitats or that has obtained enough room for development (Table 5.2). The case farm with no impact on nature or room for development emits $7,225 \mathrm{~kg}$ of $\mathrm{NH}_{3}$ at farm level after expansion and the case farm with impact on nature and no room for development $2,688 \mathrm{~kg}(0.7 * 1,750+0.45 * 3,250)$. Since room for development is expected to be limited, we can assume that many farmers near nature areas will have to deal with no room for development being available.

Table 5.2 Stable types, ammonia emission and extra year costs for three situations near a Natura 2000 area for a finisher farm that wants to expand from 2,500 to 5,000 places

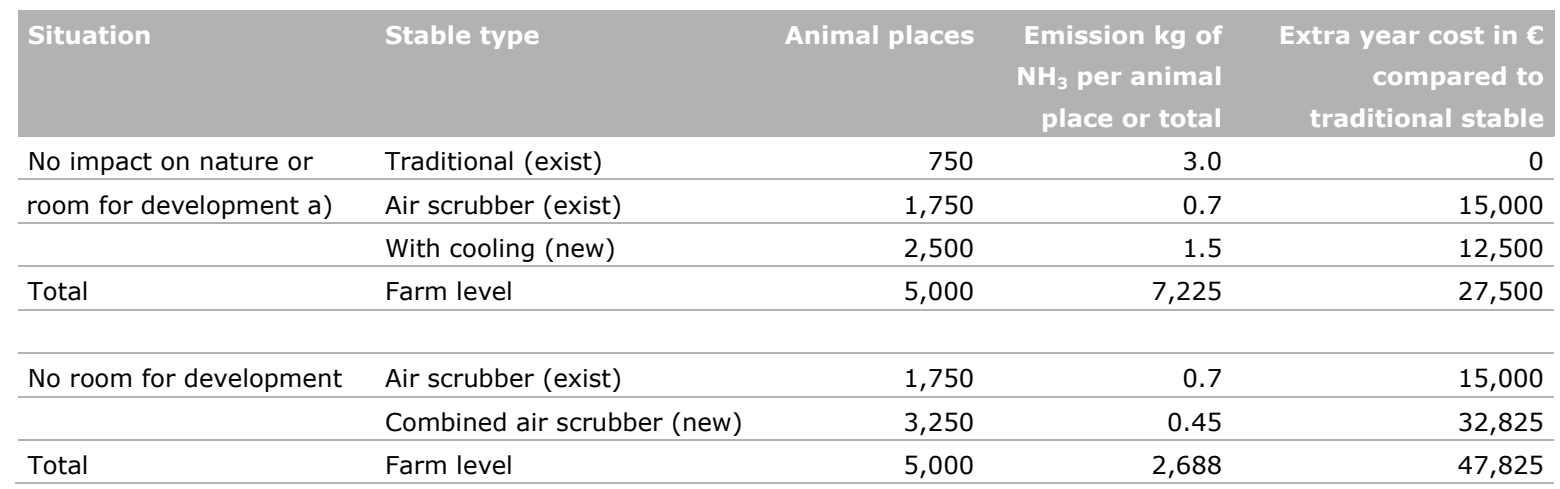

a) With room for development impact on nature may be at maximum 3 mol per ha. 


\subsubsection{Dairy cows}

\section{Expand the production from 120 to 240 dairy cows.}

A traditional cubicle housing system with slatted floor and a recirculation manure pit is taken into account, with an ammonia emission of $11.0 \mathrm{~kg}$ per animal place per year $(1,320 \mathrm{~kg}$ of ammonia deposition from housing). All the manure is stored under the stable floor.

Two scenarios regarding the availability of room for development are considered:

- There is no room for development

- There is room for development available for the maximum of $8.6 \mathrm{~kg} \mathrm{NH}$ per animal place in 2018 .

In the 70 s and 80 s dairy farmers changed en masse from tied to cubicle houses. From the beginning of the 80s till 2015 farms were limited by the milk quota. Buying milk quota was expensive and the incomes were sufficient, which is why many of farmers did not change their farm between the 80 s and 2013. As from 2013, when it was known that the milk quota would be abolished, many new dairy housing systems were built. That is why for this study we assume the situation that farmers who want to expand have old housing systems from the 70s or 80s, that are written off, and that farmers will build a new stable for all the 240 cows.

A farm that has no significant negative impact on nitrogen-sensitive habitats, has to build a stable for 240 cows, with at most an ammonia emission of $8.6 \mathrm{~kg}$ of $\mathrm{NH}_{3}$ per animal place. The same accounts for a farm that does have a negative influence on nitrogen-sensitive nature areas, but is able to obtain enough room for development. This study assumes on average more than 720 grazing hours per cow per year. For dairy cattle with more than 720 grazing hours a year, the housing emission of ammonia per animal place is $5 \%$ lower than for dairy cattle with less than 720 grazing hours (Appendix 3 ).

A farm that is not able to obtain room for development and that has a total lodge ammonia emission of $1,320 \mathrm{~kg}$ of $\mathrm{NH}_{3}$, cannot increase the total ammonia emission above this $1,320 \mathrm{~kg}$ of $\mathrm{NH}_{3}$ after expanding. Taking into account 240 cows, that means an emission of no more than $5.5 \mathrm{~kg}$ of $\mathrm{NH}_{3}$ per animal place per year. This can only be achieved by changing the current housing system for a new low-emission stable. Actually, in this case a few cubicle housing systems apply, which are slatted floor with a balling rubber top layer and seal off flaps in the grid chinks and stables with air scrubbers. In other cases, with a different amount of cows, a tied stable also may be an option. A farm that has no significant negative impact on nitrogen-sensitive habitats could build a stable with longitudinal grooves, but a farm that has significant negative impact on nitrogen-sensitive habitats has to build for instance a stable with an air scrubber. The difference in housing costs between these two stables are $€ 63.30((€ 65+€ 6.70)-(€ 7.30+€ 1.10))$ per cow place per year (Table 5.3) and at farm level $€ 15,825$ per year.

Table 5.3 Extra investment and extra year cost per animal place for three different stables for housing of dairy cows in place of a traditional stable

\begin{tabular}{llrrr} 
Type of stable & Stable number & $\begin{array}{r}\text { Extra investment } \\
\text { (c) b) }\end{array}$ & $\begin{array}{r}\text { Extra year cost } \\
\text { investment (c) }\end{array}$ & $\begin{array}{r}\text { Extra year cost } \\
\text { exploitation ( })\end{array}$ \\
Stable with longitudal grooves & A 1.24 & 86 & 3.30 & 1.10 \\
\hline Stable with cassettes and slides & A 1.13 & 405 & 65.00 & 0.00 \\
\hline Stable with air scrubber a) & A 1.17 & 648 & 65.00 & 6.70 \\
\hline
\end{tabular}

a) This stable is mechanical ventilated. Common is that al stables for dairy are natural ventilated; b) Total investment traditional stable $€ 4,000$ per animal place; interest 3.5\%; depreciation $4 \%$.

Source: Izak Vermeij, 2017, WUR (Wageningen Livestock Research). 


\section{Conclusion}

A dairy farm that has a negative influence on nitrogen-sensitive nature areas and no room for development yearly has about $€ 15,000$ higher housing costs when it expands from 120 to 240 dairy cows than a farm that has no significant negative impact on nitrogen-sensitive habitats or enough room for development (Table 5.4). The case farm with no impact on nature or room for development emits after expansion $2,064 \mathrm{~kg}$ of $\mathrm{NH}_{3}$ at farm level and the case farm with impact on nature and no room for development $1,164 \mathrm{~kg}\left(4.85^{*} 240\right)$. Since the room for development is expected to be limited, we can assume that many farmers near nature areas will have to deal with no room for development being available.

Table 5.4 Stable types, ammonia emission and extra year costs to three situations near a Natura 2000 area for a dairy farm that wants to expand from 120 to 240 cow places

\begin{tabular}{|c|c|c|c|c|}
\hline Situation & Stable type & Animal places & $\begin{array}{r}\text { Emission } \mathrm{kg} \text { of } \\
\mathrm{NH}_{3} \text { per animal } \\
\text { place or total }\end{array}$ & $\begin{array}{r}\text { Extra year cost in } € \\
\text { compared to } \\
\text { traditional stable }\end{array}$ \\
\hline Total & Farm level & 240 & 2,064 & 2,016 \\
\hline No room for development & Air scrubber & 240 & 4.85 & 17,208 \\
\hline Total & Farm level & 240 & 1,164 & 17,208 \\
\hline
\end{tabular}

a) With room for development impact on nature may be at maximum $3 \mathrm{~mol}$ per ha.

\subsubsection{Broilers}

\section{Expand the production from 300,000 to 600,000 broilers. Roughly speaking, that is from 40,000 to 80,000 animal places.}

The most common Dutch housing system in 2015 is taken into account, which is a loose housing system with mixed air ventilation and solid manure, with an ammonia emission of $0.037 \mathrm{~kg}$ per animal place per year.

Two scenarios regarding the availability of room for development are considered:

- There is no room for development

- There is room for development available for the maximum of $0.035 \mathrm{~kg} \mathrm{NH}_{3}$ per animal place in 2018.

A farm that has no significant negative impact on nitrogen-sensitive habitats and that wants to expand with 40,000 broilers has to build a housing system with an ammonia emission of at maximum $0.035 \mathrm{~kg}$ per animal place per year. For instance a stable with heaters. The same accounts for a farm that does have a negative influence on nitrogen-sensitive nature areas, but is able to obtain enough room for development to emit $1,400 \mathrm{~kg}$ of $\mathrm{NH}_{3}$.

A farm that is not able to obtain room for development and that has a total lodge ammonia emission of $1,480 \mathrm{~kg}$ of $\mathrm{NH}_{3}$, cannot increase the total ammonia emission above this $1,480 \mathrm{~kg}$ of $\mathrm{NH}_{3}$ after expanding. This can be achieved by changing the existing house with tube heating $\left(480 \mathrm{~kg}\right.$ of $\left.\mathrm{NH}_{3}\right)$. Then there are investment cost for installation of the tube heating system. This investment cost are about $15 \%$ of them for newly built stables. The equipment for mixed air ventilation has a residual value and can be sold. In addition, the farmer may save energy costs compared to a stable with mixed air ventilation. As a result, the yearly costs of the altered stable are pretty similar to the costs in the old situation (Vermeij, 2017).

In addition, to keep the 40,000 broilers, a new stable with an ammonia emission of at most $1,000(1,480-480) \mathrm{kg}$ of $\mathrm{NH}_{3}$ or $1,160(1,480-320) \mathrm{kg}$ of $\mathrm{NH}_{3}$ emission must be built. That is an 
emission of 0.025 or $0.029 \mathrm{~kg}$ of $\mathrm{NH}_{3}$ per animal place, or on average $0.027 \mathrm{~kg}$ of $\mathrm{NH}_{3}$ per animal place. A stable with a maximum of $0.027 \mathrm{~kg}$ of $\mathrm{NH}_{3}$ per place is a stable with a heat exchanger (Table 5.3, E 5.11). This stable has higher investment costs than a stable with heaters, but the savings on energy costs are higher. Thus there are no extra costs for this stable.

For the difference in investment and year costs for the stables that have to be built for broilers when expanding, see Table 5.5. A farm that has no significant negative impact on nitrogen-sensitive habitats and that wants to expand, has to build at least a housing system with heaters (E 5.14). Due to greater savings at energy costs, this stable is even cheaper than a traditional housing system.

Table 5.5 Extra investment and extra year cost in per animal place per year for four different stables for housing of broilers in place of a stable for mixed air ventilation

\begin{tabular}{|c|c|c|c|c|}
\hline Type of stable & Stable number & $\begin{array}{r}\text { Extra investment } \\
\text { (c) a) }\end{array}$ & $\begin{array}{l}\text { Extra year cost } \\
\text { investment (C) }\end{array}$ & $\begin{array}{l}\text { Extra year cost } \\
\text { exploitation }(\varepsilon)\end{array}$ \\
\hline Stable with heaters & E 5.14 & 0.20 & 0.03 & -0.06 \\
\hline Stable with tube heating & E 5.15 & 0.60 & 0.06 & -0.06 \\
\hline Stable with heat exchanger & E 5.11 & 0.90 & 0.09 & -0.14 \\
\hline
\end{tabular}

a) Total investment traditional stable $€ 15$ per animal place; interest $3.5 \%$; depreciation $4 \%$.

Source: Izak Vermeij, 2017, WUR (Wageningen Livestock Research).

\section{Conclusion}

Broiler farms that want to expand, typically need to invest in housing systems with heaters. Note that these stables are cheaper than traditional housing systems, due to greater savings of energy costs. Therefore, a broiler farm that has no negative influence on nitrogen-sensitive nature areas or that has obtained enough room for development, has on average $€ 1,200$ lower housing costs when it expands from 40,000 to 80,000 broilers than a farm with traditional housing. A farm that has a significant negative impact on nitrogen-sensitive habitats and does not have any room for development, will even have $€ 2,000$ lower housing costs when it expands (Table 5.6). Since the room for development is expected to be limited, we can assume that many farmers near nature areas will have to deal with no room for development being available.

Table 5.6 Stable types, ammonia emission and extra year costs to three situations near a Natura 2000 area for a broiler farm that wants to expand from 40,000 to 80,000 places

\begin{tabular}{|c|c|c|c|c|}
\hline Situation & Stable type & Animal places & $\begin{array}{r}\text { Emission kg of } \\
\mathrm{NH}_{3} \text { per animal } \\
\text { place or total }\end{array}$ & $\begin{array}{r}\text { Extra year cost in } € \\
\text { compared to mixed } \\
\text { air ventilation }\end{array}$ \\
\hline room for development a) & Stable with heaters (new) & 40,000 & 0.035 & $-1,200$ \\
\hline Total & Farm level & 80,000 & 2,880 & $-1,200$ \\
\hline \multirow[t]{2}{*}{$\begin{array}{l}\text { No room for } \\
\text { development }\end{array}$} & $\begin{array}{l}\text { Tube heating (changing } \\
\text { existing stable) }\end{array}$ & 40,000 & 0.012 & 0 \\
\hline & Heat exchanger (new) & 40,000 & 0.021 & $-2,000$ \\
\hline Total & Farm level & 80,000 & 1,320 & $-2,000$ \\
\hline
\end{tabular}

a) With room for development impact on nature may be at maximum $3 \mathrm{~mol}$ per ha. 


\subsection{Denmark}

\subsubsection{General}

The calculation of additional costs caused by the proximity to ammonia-sensitive nature and neighbouring livestock farms take outset in the case farms. The calculations consider the case of a $100 \%$ expansion in production for the case farms holding finishers, dairy cows and broilers respectively. Costs calculations are done for each case farm situated at a distance of $400 \mathrm{~m}$ from ammonia-sensitive nature (Category 1-3). The calculations will include 0-2 neighbouring livestock farms. For farms situated 2,000 $\mathrm{m}$ from a nature area there are no extra restrictions for the case farms and also not for dairy and broiler case farms located near Category 2 and 3 nature.

Table 5.7 show the reduction requirements of the case farms in the case of an expansion of $100 \%$ of their production when situated $400 \mathrm{~m}$ from Category 1 nature and for finishers also Category 2 and 3 nature. Reading the table downwards, the type of case farm is illustrated together with its basic emissions with no further technology requirements versus emissions with BAT requirements. Reading the table towards the right the allowed ammonia emission from the farm is shown for the number of neighbours affects the allowed emission level. Not all nature types as well as number of neighbours are relevant for all situations for the case farms.

The calculations of the allowed emissions are carried out by the Environmental Protection Agency using the computer program provided by the Agency located on 'Husdyrgodkendelse.dk'.

In this case, a farm with 7,215 finishers (1,945 pig units) $400 \mathrm{~m}$ from a nature area (Category 1-3) applies for a permit to expand its operations with $100 \%$ to $7,215+7,215$ finishers (from 1,945 to 3,890 pig units). The basic legally allowed (general ammonia requirement) for this farm has been calculated by the Environmental Protection Agency to $5,682 \mathrm{~kg} \mathrm{NH}_{3}-\mathrm{N} /$ year in the case of no nature in the vicinity. In the application for a permit, however, the farm reports its emissions with one or more BAT technologies installed and should arrive at $5,040 \mathrm{~kg} \mathrm{NH}-\mathrm{N}$ in yearly emissions as calculated by the Environmental Protection Agency, in order to get a permit to expand the livestock production. The size of the farm is the same type used for the lowest BAT emission standards.

If the farm is situated near Category 1 nature, a habitat type inside a Natura 2000 area, and has no neighbours, the farm must install enough technology to reduce emissions even further, to 2,989 $\mathrm{kg}$ $\mathrm{NH}_{3}-\mathrm{N}$ /year, corresponding to a reduction in emissions of $47 \%$ from the baseline without BAT and $40 \%$ compared to the baseline with BAT. If the farm has 1 neighbour, the farm must install technology reducing emissions by $71 \%$ to $1,642 \mathrm{~kg} \mathrm{NH}_{3}-\mathrm{N}$ compared to the baseline without BAT.

In case of an expansion near Category 2 and 3 nature the allowed emission is 4,066 $\mathrm{kg} \mathrm{NH}-\mathrm{N}$ and $6,907 \mathrm{~kg} \mathrm{NH}-\mathrm{N}$ respectively. The reduction required is $28 \%$ for Category 2 while no reduction is needed for the case farm situated near Category 3 nature compared to the baseline scenario.

The results for dairy and broilers follow the same pattern, although the ammonia requirement for dairy farms with no neighbours near Category 1 nature is higher than the baseline requirement and so there will be no additional requirements due to the production's proximity to Category 1 nature.

The requirements for finishers are also shown in Figure 5.1. The BAT requirement of $0.35 \mathrm{~kg} \mathrm{NH}-\mathrm{N}$ equals index 100. It is clear that the emission for the same type of stable has been reduced from 2005/06 until now. It can also be noted that the requirements for Category 1 with one or more livestock farms require a larger reduction as the emission levels are more than $60 \%$ of the BAT emission level. The total emissions will in that case be lower than the initial emission from the farm before the expansion and so the expansion will actually lead to lower overall emissions if they are carried out. 
Table 5.7 Allowed ammonia emissions per year from case farms situated within $400 \mathrm{~m}$ of a nature area and depending on nature type and number of neighbours when expanding by $100 \%, \mathrm{~kg} \mathrm{NH}_{3}-\mathrm{N}$

\begin{tabular}{|c|c|c|c|c|c|c|}
\hline \multirow{2}{*}{$\begin{array}{l}\text { Farm } \\
\text { type }\end{array}$} & \multirow{2}{*}{$\begin{array}{l}\text { Nature } \\
\text { type }\end{array}$} & \multirow{2}{*}{$\begin{array}{c}\text { Baseline } \\
\text { emission b) }\end{array}$} & \multirow{2}{*}{$\begin{array}{c}\text { BAT } \\
\text { emission b) }\end{array}$} & \multicolumn{3}{|c|}{ No. of neighbours } \\
\hline & & & & 0 & 1 & $>1$ \\
\hline \multirow[t]{6}{*}{ Finishers } & Category 1 & \multirow{6}{*}{$\begin{array}{c}\text { Base = 5,682 kg } \\
0.39 \mathrm{~kg} / \text { animal }\end{array}$} & \multirow{6}{*}{$\begin{array}{l}\mathrm{BAT}=5,040 \mathrm{~kg} \\
0.35 \mathrm{~kg} / \text { animal }\end{array}$} & $2,989 \mathrm{~kg}$ & $1,642 \mathrm{~kg}$ & $835 \mathrm{~kg}$ \\
\hline & & & & $0.21 \mathrm{~kg} / \mathrm{animal}$ & $0,11 \mathrm{~kg} /$ animal & $0,06 \mathrm{~kg} /$ animal \\
\hline & Category 2 & & & $4,066 \mathrm{~kg}$ & - & - \\
\hline & & & & $0.28 \mathrm{~kg} /$ animal & & \\
\hline & Category 3 & & & $6,907 \mathrm{~kg} \mathrm{a)}$ & - & - \\
\hline & & & & $0.48 \mathrm{~kg} /$ animal & & \\
\hline \multirow[t]{2}{*}{ Dairy c) } & Category 1 & Base $=2,690 \mathrm{~kg}$ & $\mathrm{BAT}=2,053 \mathrm{~kg}$ & $2,809 \mathrm{~kg} \mathrm{a})$ & $1,592 \mathrm{~kg}$ & $1,052 \mathrm{~kg}$ \\
\hline & & $11.4 \mathrm{~kg} /$ animal & $8.55 \mathrm{~kg} /$ animal & $12.0 \mathrm{~kg} /$ animal & $6.63 \mathrm{~kg} /$ animal & $4.38 \mathrm{~kg} /$ animal \\
\hline \multirow[t]{2}{*}{ Broilers c) } & Category 1 & Base $=3,838 \mathrm{~kg}$ & $\mathrm{BAT}=3,325 \mathrm{~kg}$ & $2,903 \mathrm{~kg}$ & $1,967 \mathrm{~kg}$ & $983 \mathrm{~kg}$ \\
\hline & & $6.4 \mathrm{~kg} / 1,000$ animals & $5.5 \mathrm{~kg} / 1,000$ animals & $4.8 \mathrm{~kg} / 1,000$ animals & $3.3 \mathrm{~kg} / 1,000$ animals & $1.6 \mathrm{~kg} / 1,000$ animals \\
\hline
\end{tabular}

a) In this case the requirement is higher than BAT; b) BAT is $30 \%$ reduction compared to the $2005 / 06$ reference technology emission; c) No extra requirements for cows and broilers for Category 2 and 3 nature.

Source: Jacobsen et al. (2017).

The case farms of Appendix 1 form the basis for the analysis of additional costs to farmers of additional ammonia regulation related to sensitive nature in Denmark. For each case farm, the baseline situation and its costs are calculated for the farm's required BAT technologies, where the most cost-effective technologies are chosen and combined to obtain the allowed BAT ammonia emission level (Table 5.7; column two). These baseline costs are compared to the farm's costs in the situations where there is additional requirements according to protection of Natura 2000 habitat (Category 1), and other protected areas (Category 2 and 3). In relation to Category 1 nature the amount of neighbour farms with animals results in stricter demands for reducing ammonia deposition at Category 1 nature. Again, the most cost-effective ammonia reducing technologies for the required emission level are chosen. Comparisons are made for farms situated 400 and 2,000 m from nature. For the case farms situated 2,000 $\mathrm{m}$ from a nature area, the maximum emissions equals the BAT emissions.

\subsubsection{Finishers}

The costs are primarily based on cost calculations and otherwise the Environment Agency's technology background economic and technology sheets (Jacobsen et al., 2017).

It is assumed that half of the case farm's finishers are situated in an old stable, where floor type cannot be changed whereas the other half, the expanded part, of the farm will be situated in a new farm where floor type can be chosen upon construction. The same is the case for slurry cooling. An overview of the technology and costs is given in Table 5.8. 


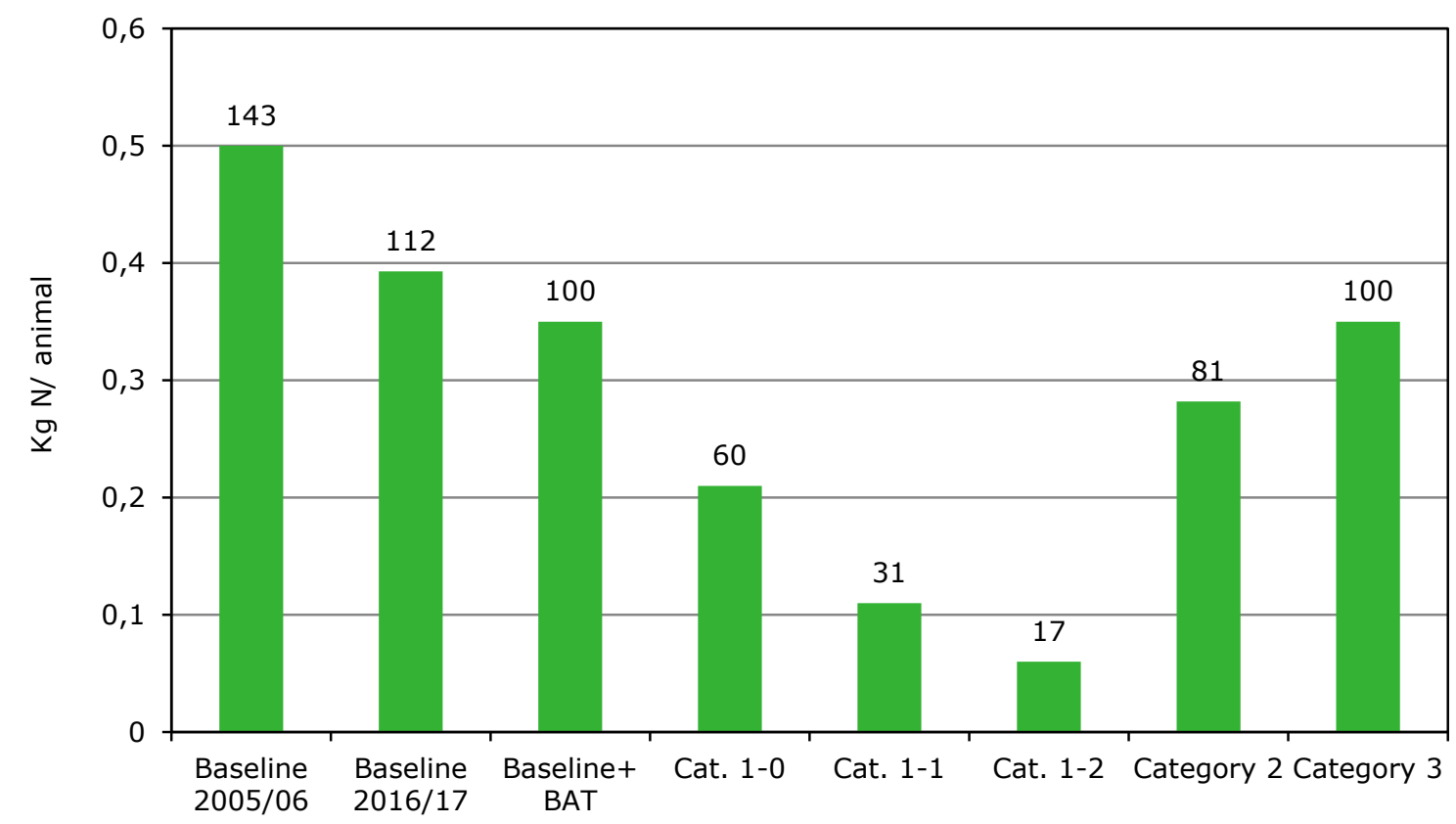

Figure 5.1 Allowed emission ( $\mathrm{kg} N$ /animal and index) for a farm with 7,215 finishers $400 \mathrm{~m}$ from nature near different categories of nature and number of neighbours. (Index $100=$ Baseline $+B A T=$

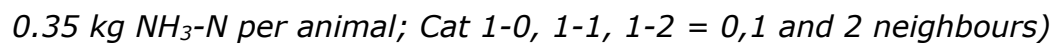

Source : Jacobsen et al. (2017).

Table 5.8 Technology and extra costs compare to traditional stable for the finisher case farm

\begin{tabular}{|c|c|c|c|}
\hline Technology & $\begin{array}{r}\text { Emission } \\
\text { reduction (\%) }\end{array}$ & Costs ( $\mathcal{C} /$ finisher) & $\begin{array}{r}\text { Costs }\left(\mathrm{C} / \mathrm{kg} \mathrm{NH}_{3}-\right. \\
\text { Nreduction) }\end{array}$ \\
\hline $25-49 \%$ solid floors & 17 & 0.54 & 8.05 \\
\hline $50-75 \%$ solid floors & 34 & 0.81 & 5.77 \\
\hline Stable acidification & 64 & 3.36 & 13.29 \\
\hline Cover of manure tank a) & 7 & 0.12 & 4.56 \\
\hline Cooling $\left.\left(20 \mathrm{~W} / \mathrm{m}^{2}\right) \mathrm{b}\right)$ & 18 & -1.07 & -17.85 \\
\hline Chemical air cleaning $(100 \%)$ & 89 & 2.82 & 7.92 \\
\hline Chemical air cleaning $(60 \%)$ & 78 & 2.15 & 6.85 \\
\hline Chemical air cleaning $(20 \%)$ & 54 & 1.34 & 6.17 \\
\hline BIological air cleaning $(100 \%)$ & 88 & 2.82 & 8.19 \\
\hline BIological air cleaning $(60 \%)$ & 82 & 2.15 & 6.71 \\
\hline BIological air cleaning $(20 \%)$ & 67 & 1.34 & 4.97 \\
\hline
\end{tabular}

a) $50 \%$ reduction of loss in storage; b) The heat is not used in this option.

Having described the costs of different ammonia reducing technologies, the following will provide the compliance costs for the case farm of achieving the required reductions as shown in Table 5.8. The emission levels, technology choices, and their costs required for the reference, BAT baseline, and the different nature types are shown in Table 5.9. The costs are shown as net costs for the technology on its own and the additional costs of being close to ammonia-sensitive nature. The additional costs of complying with nature specific ammonia requirement are calculated as the costs of the specific technology necessary in each case minus the costs of installing $50-75 \%$ solid floors to comply with BAT standards. 
Table 5.9 Technology choices and their additional housing costs compared to adhering to BAT of the Finisher case farm $400 \mathrm{~m}$ from nature

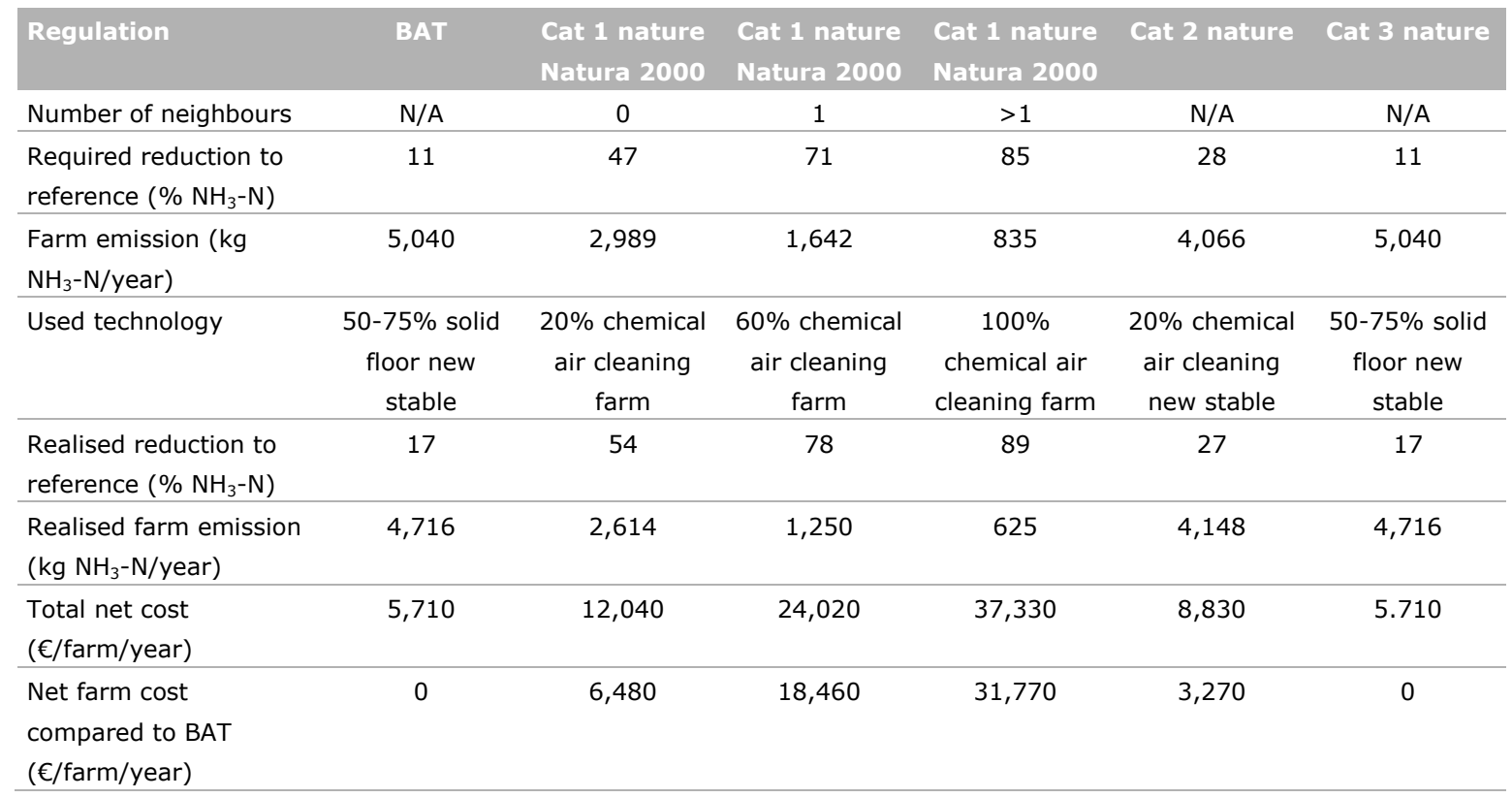

Source: Jacobsen et al. (2017).

The case farm emits $5,682 \mathrm{~kg} \mathrm{NH}-\mathrm{N}$, i.e. to adhere to the general BAT requirements it needs to reduce to emissions to $5,040 \mathrm{~kg}$, corresponding to an $11 \%$ reduction. To achieve this, the farm can install low emission flooring in the new stable housing 7,215 finishers, reducing emissions by $34 \%$ in the new stable and $17 \%$ in total. The new emission level for the farm is thus $4,716 \mathrm{~kg} \mathrm{NH}-\mathrm{N}$.

The additional yearly costs of the technology is calculated as $€ 5,710$. Since all farms need to adhere to this type of requirement, these costs and the emission level serve as a baseline for determining additional costs induced by additional requirements for nature protection purposes.

If the case farm is situated $400 \mathrm{~m}$ from a Natura 2000 site (Category 1 ) and has no neighbours, the farm needs to reduce emissions by $47 \%$ to $2,989 \mathrm{~kg} \mathrm{NH}-\mathrm{N}$. This can be done by installing $20 \%$ chemical air cleaning in both the old and new stable. This will entail yearly net costs of $€ 12,040$ and compared to BAT an additional yearly cost of $€ 6,480 /$ farm.

When situated close to a Natura 2000 site (Category 1) and having 1 livestock neighbour, the farm needs to reduce emissions by $71 \%$ to $1,642 \mathrm{~kg} \mathrm{NH}-\mathrm{N}$. This emission reduction can be reached by installing a chemical air cleaner in the old and the new stable, although combined with a higher ventilation capacity of $60 \%$. This entails yearly net costs of $€ 24,020 /$ farm, and additional costs of $€ 18,460 /$ farm when comparing to installing the BAT technology.

Having 2 livestock neighbours or more while being $400 \mathrm{~m}$ from a nature Category 1 area, the farmer needs to reduce emission by $85 \%$ to $835 \mathrm{~kg} \mathrm{NH}-\mathrm{N}$. By installing a higher ventilation capacity with a chemical air cleaner, emissions can be reduced to $835 \mathrm{~kg} \mathrm{NH}-\mathrm{N}$. This requires a yearly net cost of $€ 37,330 /$ farm or an additional cost of $€ 31,770$ /farm when comparing to the BAT baseline.

Adhering to ammonia reduction requirements when situated nearby Category 2 nature entails lower costs. In this case, the farmer can install chemical air cleaning in the new stable and achieve an overall reduction of $28 \%$ for the farm as a whole. The net costs of this technology are calculated as $€ 8,830 /$ farm per year and when comparing to installing BAT technology, the additional costs are $€ 3,270 /$ farm per year. 


\subsubsection{Dairy cows}

For dairy farms there are few options and the reduction level is from 7 to $50 \%$ (Table 5.10 ). The cost per cow is from $€ 9.90$ to $€ 91.30$. Acidification has been used on many farms and so it is a surprise that the cost are so high. In some cases the farms will gain higher yields or avoid more expensive applications in the field which is not included here.

Table 5.10 Overview of technologies and additional costs for the case farm

\begin{tabular}{|c|c|c|c|}
\hline Technology & $\begin{array}{r}\text { Reduction } \\
(\%)\end{array}$ & $\begin{array}{l}\text { Costs per } \\
\text { cow (€) }\end{array}$ & $\begin{array}{r}\text { Cost per } \\
\text { kg NH}(\varepsilon)\end{array}$ \\
\hline Stable acidification & 50 & 91.30 & 16.25 \\
\hline Wire draw dredger & 25 & 18.10 & 6.45 \\
\hline Robot dredger & 25 & 17.70 & 6.30 \\
\hline
\end{tabular}

a) $50 \%$ reduction of loss in storage.

To adhere to BAT when expanding from 120 to 240 dairy cows, the dairy farm needs to achieve ammonia reductions of $24 \%$ compared to the baseline/reference stable of $2,690 \mathrm{~kg} \mathrm{NH}-\mathrm{N}$. This corresponds to a total emission of $2,053 \mathrm{~kg} \mathrm{NH}_{3}-\mathrm{N}$ (Table 5.11). To adhere to this emission level, the chosen technologies entail installing wire drawn dredgers in both the old and the new stable. Another option would be to install, in the new stable, low emission flooring and dredgers which reduces emission by $50 \%$ thus achieving total reduction of $25 \%$ for the entire farm. Dredgers in both stables achieve an emission reduction of $25 \%$ and a combined yearly net cost incl. the value of $\mathrm{N}$ fertiliser of $€ 3,640 /$ farm.

If the dairy case farm is situated close to Natura2000 areas (Category 1 ) and has no neighbours in the proximity, the allowed emission is $2,809 \mathrm{~kg} \mathrm{NH}-\mathrm{N}$. This is higher than the reference and $37 \%$ higher than the BAT level. The explanation is that the allowed emission is based on a detailed calculation in the program which in this case allows a larger emission than in the BAT standards. It is however assumed that all farms need to adhere to the BAT requirements, and thus the farm situated near Natura 2000 and with no neighbours, is in this analysis assumed to install the BAT technology as described above. This means that there are no additional costs for the case farm compared to BAT when in proximity to Natura 2000 while having no neighbours.

Being in proximity of Category 1 nature and having one neighbour nearby, the farm has to reduce emissions to $1,592 \mathrm{~kg} \mathrm{NH}-\mathrm{N}$, which is $41 \%$ compared to the reference situation with no technology. The chosen technology to achieve this is to install acidification in both the new and existing stable. This entails yearly net costs of $€ 15,730$ /case farm including the value of $N$ fertiliser, which compared to the BAT technology is an additional cost of $€ 12,095 /$ farm. A situation where the emission requirement is fulfilled using partly acidification and dredgers might have been slightly cheaper, but it might involve higher costs related to storage, which is not included in the calculation.

Having two or more neighbours while also being in proximity of Category 1 nature, the farm needs to reduce ammonia emissions by $61 \%$ to $1,052 \mathrm{~kg} \mathrm{NH}-\mathrm{N}$. In order to achieve this emission level, the chosen technology in the table below is to install stable acidification in both stables and dredgers in the new stable. This enables a reduction of $75 \%$ in the new stable as the technologies are additive $(50 \%+25 \%)$ and a reduction of $50 \%$ in the existing stable, and thereby a total reduction of $63 \%$. This entails a net cost including the value of $\mathrm{N}$ fertiliser of $€ 17,915$ yearly for the case farm. Compared to BAT, the additional yearly net cost are $€ 14,280 /$ farm. 
Table 5.11 Technology choices and their additional housing costs compared to adhering to BAT for the dairy case farm $400 \mathrm{~m}$ from nature

\begin{tabular}{|c|c|c|c|c|}
\hline Regulation & BAT & $\begin{array}{l}\text { Cat } 1 \text { nature } \\
\text { Natura } 2000\end{array}$ & $\begin{array}{l}\text { Cat } 1 \text { nature } \\
\text { Natura } 2000\end{array}$ & $\begin{array}{l}\text { Cat } 1 \text { nature } \\
\text { Natura } 2000\end{array}$ \\
\hline Number of neighbours & N/A & 0 & 1 & $>1$ \\
\hline Farm emission (kg NH $\mathrm{N}_{3}-\mathrm{N} /$ year) & 2,053 & 2,053 & 1,592 & 1,052 \\
\hline $\begin{array}{l}\text { Realised reduction to reference } \\
\left(\% \mathrm{NH}_{3}-\mathrm{N}\right)\end{array}$ & 25 & 25 & 50 & 63 \\
\hline $\begin{array}{l}\text { Realised farm emission ( } \mathrm{kg} \mathrm{NH} \mathrm{N}_{3}^{-} \\
\mathrm{N}) \text { year) }\end{array}$ & 2,018 & 2,018 & 1,345 & 1,009 \\
\hline $\begin{array}{l}\text { Net farm cost compared to BAT } \\
\text { ( } € / \text { farm/year) }\end{array}$ & 0 & 0 & 12,095 & 14,280 \\
\hline
\end{tabular}

Source: Jacobsen et al. (2017).

\subsubsection{Broilers}

For the broiler case farm, the ammonia reducing technology is limited to the heat exchanger. As this reduces ammonia emissions by $30 \%$, the case farms being in proximity to Natura 2000 at the same time as having one or more neighbours do not have the possibility to expand at this magnitude.

Table 5.12 compares to the costs of installing heat exchanger technology to achieve larger ammonia reductions than the BAT level which all farms have to adhere to. Installing a heat exchanger in the new stable reduces the farm's emissions by $15 \%$ from 3,838 to $3,262 \mathrm{~kg} \mathrm{NH}_{3}-\mathrm{N}$ and requires a yearly net cost of $€ 4,325$ per farm.

To achieve the allowed emission level when the case farm is situated near Category 1 sites and does not have neighbours in the proximity, it is necessary to install the heat exchanger in both the new and old stable to achieve a reduction of $24 \%$ compared to no technology. The heat exchanger reduces emissions by $30 \%$ in both stables. Thus, the farm's total emissions are in this case $2,687 \mathrm{~kg} \mathrm{NH}_{3}-\mathrm{N}$. Assuming that costs are proportional to the number of chickens, this entails additional yearly net costs compared to the BAT level of $€ 4,140$ /farm.

Beyond this emissions reduction level, it will with the current technology list by the Environmental Protection Agency, not be feasible to achieve the necessary emissions reductions to be able to expand and double the case farm when it is situated near Natura 2000 areas and has neighbours. 
Table 5.12 Technology choices and their additional housing costs compared to adhering to BAT for the broiler case farm $400 \mathrm{~m}$ from nature

\begin{tabular}{|c|c|c|c|c|}
\hline \multirow[t]{2}{*}{ Regulation } & \multirow[t]{2}{*}{ BAT } & Cat 1 nature & Cat 1 nature & Cat 1 nature \\
\hline & & Natura 2000 & Natura 2000 & Natura 2000 \\
\hline Number of neighbours & N/A & 0 & 1 & $>1$ \\
\hline Farm emission ( $\mathrm{kg} \mathrm{NH}-\mathrm{N} /$ year) & 3,325 & 2,903 & 1,967 & 983 \\
\hline $\begin{array}{l}\text { Realised reduction to reference } \\
\left(\% \mathrm{NH}_{3}-\mathrm{N}\right)\end{array}$ & 15 & 30 & a) & a) \\
\hline $\begin{array}{l}\text { Realised farm emission ( } \mathrm{kg} \mathrm{NH}_{3}- \\
\mathrm{N} / \text { year) }\end{array}$ & 3,262 & 2,687 & a) & a) \\
\hline
\end{tabular}

a) Not possible.

Source: Jacobsen et al. (2017).

\subsubsection{Summery for the case farms}

The results from the case farms are summarised in Table 5.13. The picture based on the three case farms is that the additional costs of being located near nature Category 1 sites are limited as long as there are no livestock neighbours. The farm costs are under $€ 7,000$.

The analysis also shows that the additional costs increase with more livestock neighbours. With one livestock neighbour the costs increase by $€ 12-18,000$ per year. For the broiler farm no technology is available to reach this required emission level.

For the case where there are two or more livestock neighbours near Category 1 nature the additional costs compared to the chosen BAT technology are around $€ 14,000$ to $€ 32,000$ per year. For the broiler farm no technology is available to reach this required emission level.

Finally, for the case farm with finishers near Category 2 and 3 areas the extra costs compared to BAT are $€ 0-3,270$.

Table 5.13 Additional costs for case farms related to ammonia requirements for case farms near Category 1-3 nature compared to BAT emission requirements

\begin{tabular}{lccccc} 
Regulation & $\begin{array}{c}\text { Cat } 1 \text { nature } \\
\text { Natura } 2000\end{array}$ & $\begin{array}{c}\text { Cat } 1 \text { nature } \\
\text { Natura } 2000\end{array}$ & $\begin{array}{c}\text { Cat } 1 \text { nature } \\
\text { Natura } 2000\end{array}$ & Cat 2 nature & Cat 3 nature \\
Number of neighbours & 0 & 1 & $>1$ & N/A & N/A \\
\hline Finishers $(€ /$ farm) & 6,480 & 18,460 & 31,770 & 3,270 & 0 \\
\hline Dairy $(€ /$ farm) & 0 & 12,095 & 14,280 & N/A & N/A \\
\hline Broilers $(€ /$ farm $)$ & 4,320 & Not possible & Not possible & N/A & N/A \\
\hline
\end{tabular}

Source: Jacobsen et al. (2017).

Caution is needed before making general conclusions based on a limited number of case farms, as they do not represent a larger sample of situations and all types of livestock. The situations will vary between farms and so other technologies might have to be used depending on the local conditions. The results here indicate that farms intending to expand their farm near Category 1 nature where there are no livestock neighbours or where the farm is near Category 2 and 3 nature sites they will typically have an additional cost in the range of $€ 0-6,500$ per year compared to BAT costs. 
For investments near Category 1 with one or more livestock neighbours the cost are higher and the technology requirement more complex. The additional costs on top of the BAT technology are from $€ 12-€ 32,000$ per year and so the costs may in some cases be too high for the farmer and so the investment will be abandoned. Also the technology options will sometimes have to be combined and in some cases the technology available cannot give the required emission reductions. This will in some cases make the farmer pursue other options such as locating the expansion on another site or moving the whole farm to a new location.

\subsection{Comparison of the Netherlands with Denmark}

While cows and broilers are produced similarly in both countries, finishers are generally produced differently in Denmark and the Netherlands (for example, finishers differ in weight). Consequently, it is not easy to compare the costs of ammonia reduction levels for finishers between both countries. In the Netherlands, the deposition in nitrogen-sensitive Natura 2000 areas and the availability of room for development determine which ammonia emission reduction measures have to be taken; in Denmark, this depends on the number of neighbouring livestock farms and nature types. In Denmark, the measures that have to be taken and the costs that come with it depend on what deposition the ammonia emission of the farm causes in Natura 2000 areas. This is also the case in the Netherlands, but there it is also relevant how much room for development is available to the farm. So also a farm that is $5,000 \mathrm{~m}$ away from a nitrogen-sensitive Natura 2000 area must take measures, if the nitrogen deposition resulting from the ammonia emission of the farm is too high. Due to these significant differences in rules, it is difficult to compare both countries with each other properly. In Table 5.14, the extra year costs are given for the case farms that want to expand by $100 \%$ for both countries. The results of Table 5.14 show that finisher farms with neighbours and close to Natura 2000 areas have to make higher costs when expanding in Denmark than finisher farms in the Netherlands. In the Netherlands, farms further away from Natura 2000 areas have to deal with higher costs than in Denmark.

The way the extra costs of housing are calculated also differs between the Netherlands and Denmark. For instance, in the Netherlands the heat exchanger for broilers is calculated assuming lower energy costs compared to the common housing system. In the Danish situation, no assumption about lower energy costs is made. As a result, the extra housing costs for broilers in the Netherlands and Denmark are very different. If in the Danish situation calculations would take into account lower energy costs, the heat exchanger would probably bear no extra costs compared to the BAT situation.

Extra fertiliser value is calculated for the Danish situation, as compared to the ammonia emission from poor housing systems, more nitrogen will stay in the manure. That is not the case in the Dutch situation, because the price of the manure in the Dutch manure market does not depend on the amount of minerals in the manure, but on the type of manure. If in Denmark also no extra fertiliser value of the manure would be calculated, the extra costs for farms with a negative impact on nitrogen-sensitive habitats in Denmark would be about $5-10 \%$ higher.

Table 5.14 Extra year costs $(€)$ compared to the farms with no significant negative impact on nitrogen-sensitive habitats for the case farms per farm in the vicinity of nature areas in Denmark and the Netherlands for different situations when expanding by $100 \%$

\begin{tabular}{|c|c|c|c|c|c|c|c|}
\hline $\begin{array}{l}\text { Country and nature } \\
\text { type }\end{array}$ & $\begin{array}{l}\text { Neighbouring } \\
\text { farms/room for } \\
\text { development }\end{array}$ & $\begin{array}{l}\text { Finisher } \\
400 \mathrm{~m}\end{array}$ & $\begin{array}{l}\text { Finisher } \\
2,000 \mathrm{~m}\end{array}$ & $\begin{array}{l}\text { Dairy } \\
400 \mathrm{~m}\end{array}$ & $\begin{array}{l}\text { Dairy } \\
2,000 \mathrm{~m}\end{array}$ & $\begin{array}{l}\text { Broiler } \\
400 \mathrm{~m}\end{array}$ & $\begin{array}{l}\text { Broiler } \\
2,000 \mathrm{~m}\end{array}$ \\
\hline \multirow[t]{2}{*}{ Natura 2000 , cat. 1} & 1 neighbour & 18,460 & 0 & 12,095 & 0 & Not possible & 0 \\
\hline & $>1$ neighbour & 31,770 & 0 & 14,280 & 0 & Not possible & 0 \\
\hline $\begin{array}{l}\text { Denmark other nature, } \\
\text { cat. } 2\end{array}$ & $\mathrm{~N} / \mathrm{A}$ & 3,270 & 0 & 0 & 0 & 0 & 0 \\
\hline Netherlands other nature & $\mathrm{N} / \mathrm{A}$ & 0 & 0 & 0 & 0 & 0 & 0 \\
\hline
\end{tabular}




\section{Discussion}

The number of farms that will expand around nature areas will be small

In both countries, the total number of farms is declining. In the Netherlands the farms close to nature areas are much smaller than the national average, where they in Denmark are only $10 \%$ smaller than the average. As smaller farms generally have more difficulty to generate a good income than bigger farms, a larger part of farms that are located near nature areas is expected to stop farming than farms that are located further away from nature.

When finisher or dairy farms that have a significant negative influence on nitrogen-sensitive Natura 2000 habitats want to expand their production, they have to make higher costs than farms that have no negative influence. This is because they have to build more expensive housing systems, that reduce ammonia emissions. As a result, it is expected that:

1. a part of the farmers that want to expand, will buy a farm located further away from nature and will expand at the new location; or

2. other farmers will choose to continue farming at the current location and combine the farm with for example recreational activities to generate more income. As nature areas provide excellent possibilities for walking and biking, farms in the vicinity of nature have good opportunities to make money in recreation, for instance by creating a farmers campsite.

Due to these aforementioned reasons, it is expected that only a small number of farms that are expanding, have a negative influence on nature. In the Netherlands, regional policy is in place to stimulate that farms with a high negative influence on nitrogen-sensitive nature are moving to areas with no negative influence on nature; the new buildings can then be partly subsidised.

\section{Difference in methods of economic calculations}

The calculation method for the economic effects of expanding farms near nature areas is not the same in the Dutch and the Danish situation. With housing systems that reduce ammonia emissions, more nitrogen will remain in manure. When this manure is used in agricultural production, less artificial fertiliser has to be used. In the Danish situation, this extra fertiliser value is calculated as less extra housing costs compared to the basis situation (BAT: Best Available Technology). In the Netherlands, this extra value is not being used in calculations, because intensive farmers generally have to sell this extra manure, for they cannot use it at their own farm. The manure price does not depend on the mineral content, but only on the type of manure.

With respect to the housing systems of broilers, there is a second methodological difference. In the Dutch situation, savings due to lower energy costs are calculated when a housing system with reduced ammonia emissions is implemented; in the Danish situation, no energy savings are calculated.

Differences in the definition of an animal between the countries

In the Netherlands, the ammonia-reduction measures and the economic calculations are based on animal places per year, whereas in Denmark they are based on the number of animals per year. An animal place is the part of a housing system that is used for keeping one animal. Moreover, the definition of a finisher and a broiler differs between the Netherlands and Denmark. Therefore, the results at animal place or animal level cannot easily be compared. For instance, in the Netherlands a pig is called a finisher if it has a live weight of about $24 \mathrm{~kg}$ or more, whereas in Denmark it has a weight of about $32 \mathrm{~kg}$ and more. Furthermore, in Denmark finishers are slaughtered when they weigh about $107 \mathrm{~kg}$ and in the Netherlands when their live weight is about $120 \mathrm{~kg}$. For this reasons, the economic results are only compared at farm level. 
Differences in agricultural production between Denmark and the Netherlands With more animals (dairy cows and poultry) in the Netherlands on the one hand and 50\% more agricultural area in Denmark on the other hand, the manure pressure in the Netherlands is much higher than in Denmark. In addition, the pig and poultry farms are concentrated in just a few regions in the Netherlands, while in Denmark they are spread more over the whole country. Moreover, there is a big difference in farm size: the number of animals on an average Danish farm is two or more times higher than in the Netherlands.

The situation for livestock production near nature seems to be quite similar in the Netherlands and Denmark. In both countries, less than $5 \%$ of the livestock production is located closer than $400 \mathrm{~m}$ to Natura 2000 areas. However, the Netherlands differs from Denmark in that more farms in Denmark are further away than 2,000 $\mathrm{m}$ from nature than in the Netherlands (about $25 \%$ of the farms in the Netherlands and $45 \%$ of the farms in Denmark).

Ammonia reduction regulation for expanding differ between Denmark and the Netherlands In 2018, the ammonia-emission regulation for storage, manure application and existing housing systems in the Netherlands is stricter than in Denmark. But for farms that want to expand it is per animal place the other way around. For those farms, the regulation in Denmark is stricter than in the Netherlands. For a farm with finishers and the size of the case farm, the maximum emission is $0.69 \mathrm{~kg}$ of $\mathrm{NH}_{3}-\mathrm{N}$ per animal place with $0,6 \mathrm{~m}^{2}$ per animal place is that $1.06 \mathrm{~kg} \mathrm{NH}_{3}-\mathrm{N}$ per $\mathrm{m}^{2}$ in Denmark. In the Netherlands, the maximum emission is $1.5 \mathrm{~kg}$ of $\mathrm{NH}_{3}(1.24 \mathrm{~kg} \mathrm{NH}-\mathrm{N})$ per animal place with $0,85 \mathrm{~m}^{2}$ per animal place it is $1.76 \mathrm{~kg}$ of $\mathrm{NH}_{3}(1.46 \mathrm{~kg} \mathrm{NH}-\mathrm{N})$ per $\mathrm{m}^{2}$. This applies to new housing systems only. All in all, the ammonia emission norms in Denmark when expanding for big farms are at least $0.4 \mathrm{~kg} \mathrm{NH}-\mathrm{N}$ per $\mathrm{m}^{2}$ living room or $27 \%$ lower (stricter) than in the Netherlands. But for farms with less than 4,750 animal places (after expanding) it is the other way round than the rules in the Netherlands are stricter.

Also for cows the norms when expanding are stricter in Denmark than in the Netherlands. For a dairy farm with the size of the case farm, the allowed emission in Denmark is $5.35 \mathrm{~kg} \mathrm{NH}-\mathrm{N}$ per animal place and in the Netherlands $8.6 \mathrm{~kg} \mathrm{NH}(7.1 \mathrm{~kg} \mathrm{NH}-\mathrm{N})$. An animal place for cows in Denmark is comparable with that in the Netherlands.

For broilers, however, the norms in the Netherlands are stricter. The allowed emission when expanding in Denmark is $0.031 \mathrm{~kg} \mathrm{NH}-\mathrm{N}$ for the case farm and $0.035 \mathrm{~kg} \mathrm{NH}(0.029 \mathrm{~kg} \mathrm{NH}-\mathrm{N})$ in the Netherlands.

Rules for emission when expanding for farms around nature areas are very different between both countries, but in Denmark they are stricter

The ammonia-emission regulation around nature areas is very different in the two countries:

- for new activities, the total nitrogen deposition on nature is relevant in the Netherlands, whereas in Denmark only deposition from agriculture is relevant;

- in the Netherlands, the rules are about extra emission compared to the present situation. In Denmark, rules are stricter in that when a farm expands, the ammonia emissions must be in most cases lower in the end than the present situation;

- in Denmark, the maximum ammonia emission depends on the distance of the farm to the nature area, the type of nature and the number of neighbouring animal farms. In the Netherlands, it depends on the extra nitrogen deposition at the nature area the initiative will have or has and the availability of room for development.

In general, it can be concluded that when the farm is located close ( $<400 \mathrm{~m}$ ) to a Natura 2000 area, the rules in Denmark are stricter than in the Netherlands. But when a farm is located 2,000 $\mathrm{m}$ away 
from a Natura 2000 area and that farm causes deposition of nitrogen in that nature area, then the rules are stricter in the Netherlands. In both countries the amount and allowed ammonia emissions by animal farms and nitrogen deposition of those farms on nature are calculated with computer programs.

Extra costs of ammonia reduction-measures differ from situation to situation and the measures the farms have to take

The extra costs farmers that are located near nature areas have to make when expanding are strongly related to the rules that apply. In Denmark, the rules for farms located close to Natura 2000 areas are stricter than in the Netherlands, while the extra costs when expanding the farm are also higher. For the finisher case farm with more than one neighbour, the extra costs in Denmark are about $€ 32,000$ per farm and in the Netherlands when no room for development is available $€ 20,500$. But when the finisher case farm is located 2,000 $\mathrm{m}$ from a Natura 2000 area and the extra deposition is more than $0.014 \mathrm{~kg}$ of nitrogen per ha per year at the Natura 2000 area, then there are no extra costs in Denmark, whereas in the Netherlands the extra costs are $€ 20,500$ when no room for development is available. For dairy and broiler farms, the situation between both countries is quite similar.

In Denmark, it is not possible for broiler farms close to Natura 2000 areas to expand by $100 \%$ if there are neighbouring livestock farms, because the ammonia emissions must be lower than the technologies that are in the list of the Environmental Protection Agency of Denmark allow for. 


\section{References and websites}

Aerius (2017). website: https://www.aerius.nl/en

Backus, C. and A. Keessen (2017). The Netherlands - national report on the legal framework for ammonia regulation of livestock installations with a particular regard to Natura 2000- sites. Utrecht, university, Draft report

CBS (2017). Den Haag, Centraal bureau voor de Statistiek, www.cbs.nl; statline

Council of State (2016). Ruling 201406537/1/R2 and 201406589/1/R2. The Hague: Council of State. Ministry of Economic Affairs \& Ministry of Infrastructure and the Environment (2015a). Programma Aanpak Stikstof 2015-2021 zoals gewijzigd na partiële herziening op 15 december 2015. The Hague.

Heer, M. de, F. Roozen and R. Maas (2017). The Integrated Approach to Nitrogen in the Netherlands: A preliminary review from a societal, scientific, juridical and practical perspective, Journal for Nature Conservation 35 (2017), pp. 101-111

http://pas. natura2000.nl/pages/veelgestelde-vragen.aspx

http://pas.natura2000.nl/pages/verdeling-van-de-depositieruimte.aspx

http://wetten.overheid.nl/BWBR0036748/2017-01-01\#Bijlage1

http://www.agrimatie.nl/ Agrarische feiten en cijfers. Den Haag, Wageningen Economic Research, website

Jacobson, B.H. and L. Stahl (2017). Economic analysis of the ammonia regulation in Denmark in relation to the Habitat directive. Copenhagen, Department of food and Resource Economics (IFRO) University of Copenhagen, Draft version $17^{\text {th }}$ October

Jansen, A.J.M., H.F. van Dobben, M.E. Nijssen, J.H. Bouwman and D. Bal (eds.), (2014). Herstelstrategieën stikstofgevoelige habitats. Ecologische onderbouwing van de Programmatische Aanpak Stikstof (PAS). Deel III: Landschapsecologische inbedding. Unie van Bosgroepen, Alterra Wageningen UR, Stichting Bargerveen \& Programmadirectie Natura 2000, Ministerie van Economische Zaken

Koeijer, T.J. de, P.W. Blokland, J.F.M. Helming and H.H. Luesink (2014). Ex ante evaluatie wetsvoorstel Voorwaarden groei melkveehouderij. Den Haag, LEI Wageningen UR, Rapport 2014-019.

Ministry of Economic Affairs, LTO, Netherlands, NZO, Nevedi, NMV, NVP, NVV, CUMELA Netherlands (2014). Overeenkomst generieke maatregelen in verband met het programma aanpak stikstof.

Ministry of Economic Affairs \& Ministry of Infrastructure and the Environment (2015a). Programma Aanpak Stikstof 2015-2021 zoals gewijzigd na partiële herziening op 15 december 2015. The Hague.

Ministry of Economic Affairs \& Ministry of Infrastructure and the Environment (2015b). Plan-MER over het programma aanpak stikstof 2015-2021. Deel 1. The Hague.

Nilsson, J. and P. Grennfelt (1988). Critical loads for sulphur and nitrogen. report from a workshop held at skokloster, Sweden 19-24 March, 1988. NORD miljørapport1988:15. Copenhagen: NORD.

PAS (2017). website: http://pas.natura2000.nl/pages/verdeling-van-de-depositieruimte.aspx

Provincie Overijssel (2015). Beleidsregel toedeling ontwikkelingsruimte Programmatische Aanpak Stikstof Overijssel 2015 segment 2, 2015/0156224, 30 juni 2015

RVO (2017). Assen, Rijksdienst Voor Ondernemend Nederland. http://www.rvo.nl/onderwerpen/agrarisch-ondernemen/mest-en-grond/mest

Smits, N.A.C. and B. Bal (eds.) (2014). Herstelstrategieën stikstofgevoelige habitats. Ecologische onderbouwing van de Programmatische Aanpak Stikstof (PAS). Deel I: Algemene inleiding herstelstrategieën: beleid, kennis en maatregelen, Alterra Wageningen UR \& Programmadirectie Natura 2000 van het Ministerie van Economische Zaken.

Smits, N.A.C., A.S. Adams, D. Bal, and H.M. Beije (eds.) (2014). Herstelstrategieën stikstofgevoelige habitats. Ecologische onderbouwing van de Programmatische Aanpak Stikstof (PAS). Deel II: Herstelstrategieën voor stikstofgevoelige habitats. Alterra Wageningen UR \& Programmadirectie Natura 2000 van het Ministerie van Economische Zaken.

Statistics Denmark (2017). Statistics overview. 
Van Bruggen, C., A. Bannink, C.M. Groenestein, B.J. de Haan, J.F.M. Huijsmans, H.H. Luesink, S.M. van der Sluis, G.L. Velthof and J. Vonk (2017). Emissies naar lucht uit de landbouw 2015. Berekeningen met het Nationaal Emissiemodel voor Ammoniak (NEMA). Draft-report. WOT Natuur \& Milieu, Wageningen UR, Wageningen.

Van Dobben, H.F., R. Bobbink, D. Bal and A. van Hinsberg (2014). Overview of critical loads for nitrogen deposition for Natura 2000 habitat types occurring in The Netherlands. Alterra report 2488. Wageningen: Alterra.

Van Zanten, M.C., R.J. Wichink Kruit, R. Hoogerbrugge, E. Van der Swaluw and W.A.J. van Pul (2017). Trends in ammonia measurements in the Netherlands over the period 1993-2014, Atmospheric Environment, 148 (2017), pp. 352-360

Vermeij, I. (2017). Investment and year cost of stables for finishers, dairy cows and broilers. Lelystad, Wageningen Livestock Research, Personal information 


\section{Appendix 1 Characteristics of the cases and the case farms before expanding}

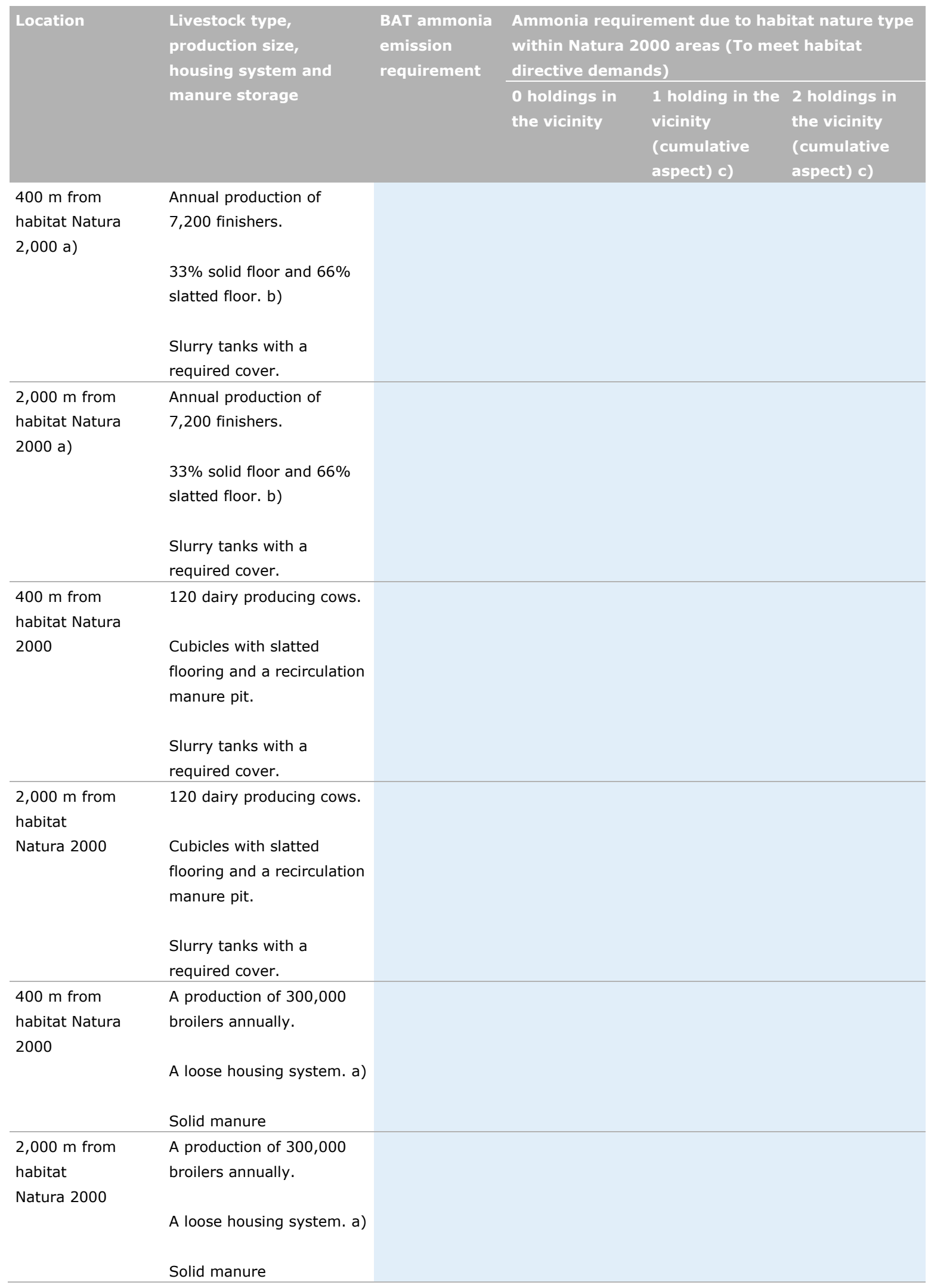

a) Also for other nature; b) For the Netherlands the most common housing system; c) For the Netherlands it depends on the room for ammonia deposition. 


\section{Appendix 2 Overview Dutch agriculture near nature}

Table A2.1 Agriculture production near nature areas in 2016

\begin{tabular}{|c|c|c|c|c|c|}
\hline Description & Netherlands & $\begin{array}{r}\text { Natura } 2000 \\
<400 \mathrm{~m}\end{array}$ & $\begin{array}{r}\text { Natura } 2000 \\
>400 \mathrm{~m} \text { and } \\
<2,000 \mathrm{~m}\end{array}$ & $\begin{array}{r}\text { Other nature } \\
<400 \mathrm{~m}\end{array}$ & $\begin{array}{r}\text { Other nature } \\
>400 \mathrm{~m} \text { and } \\
<2,000 \mathrm{~m}\end{array}$ \\
\hline Number of farms & 55,681 & 3,639 & 12,605 & 17,796 & 7,067 \\
\hline \multicolumn{6}{|l|}{ Total agricultural area $(: 1,000 \mathrm{ha})$} \\
\hline Grassland & 975 & 79 & 232 & 348 & 157 \\
\hline Green feed crops & 216 & 13 & 49 & 71 & 39 \\
\hline Arable crops & 504 & 25 & 122 & 142 & 90 \\
\hline Horticulture & 101 & 6 & 25 & 25 & 20 \\
\hline \multicolumn{6}{|l|}{ Number of animals $(: 1,000)$} \\
\hline Cattle total & 4,251 & 278 & 976 & 1,346 & 891 \\
\hline Dairy cows & 1,745 & 101 & 382 & 541 & 387 \\
\hline Young dairy cattle & 1,317 & 77 & 286 & 411 & 266 \\
\hline Sheep & 784 & 83 & 186 & 282 & 62 \\
\hline Goats & 500 & 21 & 120 & 142 & 163 \\
\hline Total pigs & 12,479 & 282 & 2,074 & 3,323 & 3,241 \\
\hline Finishers & 5,726 & 112 & 943 & 1,570 & 1,378 \\
\hline Sows & 931 & 25 & 157 & 248 & 262 \\
\hline Chickens total & 105,620 & 1,954 & 19,407 & 28,201 & 23,602 \\
\hline Laying hens (incl. youngsters) & 46,212 & 822 & 10,382 & 16,000 & 9,538 \\
\hline Broilers & 49,188 & 728 & 7,735 & 10,071 & 10,738 \\
\hline Parents for broilers & 8,742 & 268 & 1,037 & 1,874 & 2,855 \\
\hline Finishers & 5,726 & 112 & 943 & 1,570 & 1,378 \\
\hline
\end{tabular}

Source: Dutch National Agricultural Census (CBS,2017), adapted by Wageningen Economic Research.

Table A2.2 Number of farms per farmtype near nature areas in The Netherlands in 2016

\begin{tabular}{|c|c|c|c|c|c|}
\hline Description & Netherlands & $\begin{array}{l}\text { Natura } 2000 \\
<400 \mathrm{~m}\end{array}$ & $\begin{array}{l}\text { Natura } 2000 \\
>400 \mathrm{~m} \text { and } \\
<2,000 \mathrm{~m}\end{array}$ & $\begin{array}{l}\text { Other nature } \\
<400 \mathrm{~m}\end{array}$ & $\begin{array}{l}\text { Other nature } \\
>400 \mathrm{~m} \text { and } \\
<2,000 \mathrm{~m}\end{array}$ \\
\hline Arable farms & 10,821 & 662 & 2,455 & 3,437 & 963 \\
\hline Horticulture farms & 7,389 & 388 & 1,582 & 1,755 & 1,411 \\
\hline Remaining culture farms & 1,612 & 137 & 546 & 575 & 197 \\
\hline Grazing animal farms & 27,910 & 2,111 & 6,348 & 9,672 & 3,156 \\
\hline - Dairy farms & 16,503 & 1,051 & 3,679 & 5,418 & 2,885 \\
\hline Shed animal farms & 4,837 & 152 & 933 & 1,345 & 954 \\
\hline - Finishers & 1,648 & 51 & 324 & 462 & 241 \\
\hline - Breeding farms & 806 & 32 & 141 & 222 & 202 \\
\hline - Other pig farms & 681 & 15 & 124 & 193 & 119 \\
\hline - Laying hen farms & 638 & 17 & 158 & 192 & 149 \\
\hline - Broiler farms & 468 & 13 & 84 & 107 & 94 \\
\hline Crop combination farms & 1,076 & 72 & 293 & 315 & 141 \\
\hline Cattle combination farms & 607 & 22 & 120 & 215 & 107 \\
\hline All other combination farms & 1,429 & 95 & 328 & 482 & 138 \\
\hline Total & 55,681 & 3,639 & 12,605 & 17,796 & 7,067 \\
\hline
\end{tabular}

Source: Dutch National Agricultural Census (CBS, 2017), adapted by Wageningen Economic Research. 
Table A2.3 The average size in agriculture area and number of animals per farm for three farm types in The Netherlands in 2016 near nature

\begin{tabular}{|c|c|c|c|c|}
\hline Description & $\begin{array}{r}\text { Natura } 2000 \\
<400 \mathrm{~m}\end{array}$ & $\begin{array}{r}\text { Natura } 2000 \\
>400 \mathrm{~m} \text { and } \\
<2,000 \mathrm{~m}\end{array}$ & $\begin{array}{r}\text { Other nature } \\
<400 \mathrm{~m}\end{array}$ & $\begin{array}{r}\text { Other nature } \\
\begin{array}{r}>400 \mathrm{~m} \text { and } \\
<2,000 \mathrm{~m}\end{array}\end{array}$ \\
\hline - Culture area (ha) & 56 & 54 & 53 & 55 \\
\hline - Dairy cows (number) & 93 & 98 & 96 & 107 \\
\hline - Culture area (ha) & 12 & 12 & 15 & 16 \\
\hline - Finishers (number) & 1,029 & 1,543 & 1,938 & 2,404 \\
\hline - Sows (number) & 244 & 251 & 343 & 285 \\
\hline \multicolumn{5}{|l|}{ Broiler farms/farm } \\
\hline
\end{tabular}

Source: Dutch National Agricultural Census (CBS, 2017), adapted by Wageningen Economic Research. 


\section{Appendix 3 Emission factors from Dutch Regeling Ammoniak en Veehouderij (RAV)}

Source: http://wetten.overheid.nl/BWBR0013629/2017-04-12

Emissiefactoren voor de berekening van de ammoniakemissie van een dierenverblijf, inclusief de emissie van de mest die in het dierenverblijf aanwezig is.

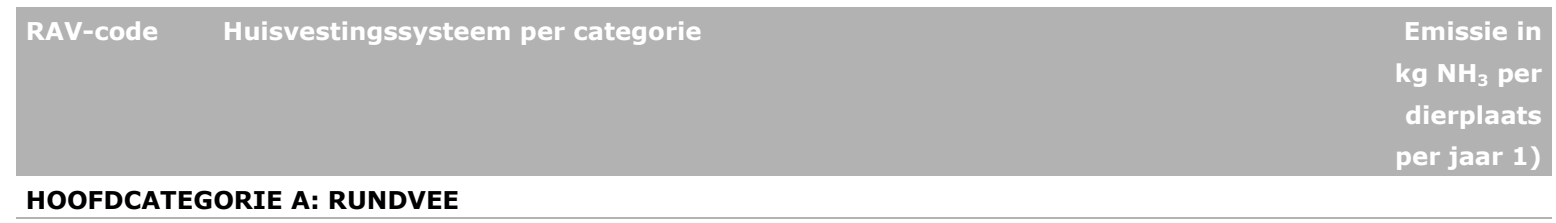

\begin{tabular}{|c|c|c|}
\hline A 1 & diercategorie melk- en kalfkoeien ouder dan 2 jaar & \\
\hline A 1.1 & $\begin{array}{l}\text { grupstal met drijfmest, emitterend mestoppervlak van grup en kelder max. } 1,2 \mathrm{~m}^{2} \text { per } \\
\text { koe(Groen Label BB 93.06.009) }\end{array}$ & 5,7 \\
\hline A 1.2 & $\begin{array}{l}\text { loopstal met hellende vloer en giergoot of met roostervloer; beide met spoelsysteem(BWL } \\
\text { 2001.28.V1) }\end{array}$ & 10,2 \\
\hline A 1.3 & $\begin{array}{l}\text { loopstal met hellende vloer en giergoot; max. } 3 \mathrm{~m}^{2} \text { mestbesmeurd oppervlak per koe(Groen } \\
\text { Label BB 93.03.003V1; BB 93.03.003/A 93.04.004V1;BB 93.03.003/B 93.04.005V1;BB } \\
\text { 93.03.003/C 93.04.006V1; BB 93.03.003/D 94.06.020V1) }\end{array}$ & 10,2 \\
\hline A 1.4 & $\begin{array}{l}\text { loopstal met hellende vloer en spoelsysteem; max. 3,75 } \mathrm{m}^{2} \text { mestbesmeurd oppervlak per } \\
\text { koe(Groen Label BB 94.02.015V1) }\end{array}$ & 9,2 \\
\hline A 1.5 & loopstal met sleufvloer en mestschuif(BWL 2010.24.V5) & 11,8 \\
\hline A 1.6 & $\begin{array}{l}\text { ligboxenstal met dichte hellende vloer, met profilering, met snelle gierafvoer met } \\
\text { mestschuif(BWL 2009.11.V4) }\end{array}$ & 11,0 \\
\hline A 1.7 & $\begin{array}{l}\text { ligboxenstal met dichte hellende vloer, met rubbertoplaag, met snelle gierafvoer met } \\
\text { mestschuif(BWL 2009.22.V4) }\end{array}$ & 11,0 \\
\hline A 1.8 & ligboxenstal met sleufvloer met noppen en mestschuif(BWL 2010.14.V4) & 11,8 \\
\hline A 1.9 & $\begin{array}{l}\text { ligboxenstal met roostervloer voorzien van een bolle rubber toplaag en afdichtflappen in de } \\
\text { roosterspleten, met mestschuif(BWL 2010.30.V4) }{ }^{28}\end{array}$ & 6,0 \\
\hline A 1.10 & $\begin{array}{l}\text { ligboxenstal met roostervloer voorzien van een bolle rubber toplaag, met mestschuif(BWL } \\
\text { 2010.31.V4) }\end{array}$ & 7 \\
\hline A 1.11 & $\begin{array}{l}\text { ligboxenstal met geprofileerde vlakke vloer met hellende sleuven, regelmatige mestafstorten } \\
\text { en met een mestschuif(BWL 2010.32. V3) }{ }^{19}\end{array}$ & 11,8 \\
\hline A 1.12 & $\begin{array}{l}\text { ligboxenstal met geprofileerde vlakke vloer met hellende sleuven, regelmatige mestafstorten } \\
\text { en mestschuif(BWL 2010.33.V4) }{ }^{19}\end{array}$ & 12,2 \\
\hline A 1.13 & $\begin{array}{l}\text { ligboxenstal met roostervloer voorzien van cassettes in de roosterspleten en mestschuif(BWL } \\
\text { 2010.34.V6) }\end{array}$ & 7 \\
\hline A 1.14 & $\begin{array}{l}\text { ligboxenstal met geprofileerde vlakke vloer met hellende sleuven, regelmatige mestafstorten } \\
\text { voorzien van afdichtflappen, met mestschuif(BWL 2010.35.V5) }\end{array}$ & 7 \\
\hline A 1.15 & $\begin{array}{l}\text { ligboxenstal met geprofileerde vlakke vloer met hellende sleuven, regelmatige mestafstorten } \\
\text { voorzien van emissiereductiekleppen en met mestschuif(BWL 2010.36.V4) }{ }^{19}\end{array}$ & 10,3 \\
\hline A 1.16 & $\begin{array}{l}\text { ligboxenstal met V-vormige vloer van gietasfalt in combinatie met een gierafvoerbuis en met } \\
\text { mestschuif(BWL 2012.01.V2) }{ }^{19}\end{array}$ & 11,7 \\
\hline A 1.17 & mechanisch geventileerde stal met een chemisch luchtwassysteem(BWL 2012.02.V3) ${ }^{19}$ & 5,1 \\
\hline A 1.18 & $\begin{array}{l}\text { ligboxenstal met V-vormige vloer van geprofileerde vloerelementen in combinatie met een } \\
\text { gierafvoerbuis en met mestschuif(BWL 2012.04.V3) }\end{array}$ & 8 \\
\hline A 1.19 & $\begin{array}{l}\text { ligboxenstal met roostervloer met hellende groeven of hellend gelegd, voorzien van } \\
\text { afdichtkleppen in de roosterspleten en met mestschuif(BWL 2012.05.V2) }{ }^{19}\end{array}$ & 11,0 \\
\hline A 1.20 & $\begin{array}{l}\text { ligboxenstal met vloer voorzien van perforaties en hellende profilering en mestschuif(BWL } \\
\text { 2012.08.V1) }{ }^{19}\end{array}$ & 10,1 \\
\hline
\end{tabular}


A 1.21 ligboxenstal met vlakke vloerplaten met tegelprofiel, hellende sleuven en regelmatige

A 1.22 ligboxenstal met sleufvloer en mestschuif en in de doorsteken, wachtruimte en doorlopen een roostervloer met bolle rubber toplaag voorzien van afdichtflappen in de roosterspleten( $B W L$

2013.03.V1)

A 1.23 ligboxenstal met geprofileerde vloerplaten met sterk hellende langssleuven met

urineafvoergat en hellende dwarsgroeven, aaneengesloten gelegd of gescheiden door mestafstorten voorzien van emissiereductiekleppen, met mestschuif(BWL 2013.04.V2)

A 1.24 ligboxenstal met vloer met sterk hellende langssleuven, de vloerplaten aaneengesloten gelegd of gescheiden door mestafstorten voorzien van afdichtflappen, met mestschuif (BWL 2013.05.V2) ${ }^{19}$

A 1.25 ligboxenstal met vlakke vloer, voorzien van geprofileerde rubber matten met een hellend profiel naar regelmatige mestafstorten voorzien van afdichtflappen, met mestschuif(BWL 2013.06.V1) ${ }^{19}$

A 1.26 ligboxenstal met hellende V-vormige vloer, voorzien van geprofileerde rubber matten, met 9,6 centrale giergoot en mestschuif(BWL 2013.07.V1) ${ }^{19}$

A 1.27 ligboxenstal met roostervloer met hellende groeven of hellend gelegd, voorzien van afdichtkleppen in de roosterspleten, met mestschuif en vernevelsysteem(BWL 2014.02.V1) ${ }^{19}$

A 1.28 Ligboxenstal met roostervloer, voorzien van rubber matten en composiet nokken met een hellend profiel, kunststofcassettes met kleppen in de roosterspleten en met mestschuif(BWL 2015.05) ${ }^{19}$

A 1.29 Ligboxenstal met geprofileerde hellende vloer met holtes voor gieropvang en -afvoer aan de 9,9 zijkant en met mestschuif(BWL 2015.06) ${ }^{19}$

D 3 diercategorie vleesvarkens, opfokberen van circa $25 \mathrm{~kg}$ tot 7 maanden, opfokzeugen van circa $25 \mathrm{~kg}$ tot eerste dekking

D $3.1 \quad$ volledig roostervloer (BWL 2001.21.V1) ${ }^{5}$

D 3.2 gedeeltelijk roostervloer

D 3.2.1 gehele dierplaats onderkelderd zonder stankafsluiter (BWL 2001.23.V1) ${ }^{5}$

D 3.2.2 mestopvang in en spoelen met $\mathrm{NH}_{3}$-arme vloeistof (inclusief aanzuren) 1,6 (Groen Label BB 93.06.010V1; BB 93.11.011; BB 93.11.011/A 95.04.024) (BWL 2001.24.V1) 5

D 3.2.3 koeldeksysteem met metalen driekantroostervloer (170\% koeloppervlak) (BWL 2001.25.V2)

D 3.2.4 mestopvang in met formaldehyde behandelde mestvloeistof in combinatie met metalen 1,0 driekantroostervloer(Groen Label BB 95.02.025V2) ${ }^{5}$

D 3.2.5 mestopvang in water in combinatie met metalen driekant roostervloer(Groen Label BB $95.10 .029 \mathrm{~V} 3)^{5}$

D 3.2.6 koeldeksysteem (200\% koeloppervlak)

D 3.2.6.1 met metalen roostervloer

D 3.2.6.1.1 emitterend mestoppervlak maximaal $0,8 \mathrm{~m}^{2}$ per varken(BWL 2010.19.V2) ${ }^{5}$

D 3.2.6.1.2 emitterend mestoppervlak maximaal $0,5 \mathrm{~m}^{2}$ (BWL 2004.08.V2) $^{5} \quad 1,2$

D 3.2.6.2 met roostervloer anders dan metaal

D 3.2.6.2.1 emitterend mestoppervlak maximaal $0,6 \mathrm{~m}^{2}$ per varken(BWL 2010.20.V2) ${ }^{5}$

D 3.2.6.2.2 emitterend mestoppervlak groter dan $0,6 \mathrm{~m}^{2}$, doch kleiner dan $0,8 \mathrm{~m}^{2}$ per varken( $(B W L$ 2001.01.v2) ${ }^{5}$

D 3.2.7 mestkelders met (water- en) mestkanaal; mestkanaal met schuine putwand

D 3.2.7.1 met metalen driekantroosters op het mestkanaal

D 3.2.7.1.1 emitterend mestoppervlak maximaal 0,18 $\mathrm{m}^{2}$ per varken(Groen Label BB 97.07.056/A 97.11.059V2) (BWL 2004.03.V2) ${ }^{5}$

D 3.2.7.1.2 emitterend mestoppervlak groter dan 0,18 $\mathrm{m}^{2}$, maar kleiner dan 0,27 $\mathrm{m}^{2}$ per varken(Groen 1,4 Label BB 97.07.056/A 97.11.059V2) (BWL 2004.04.V2) ${ }^{5}$

D 3.2.7.2 met roosters anders dan metalen driekant op het mestkanaal

D 3.2.7.2.1 emitterend mestoppervlak maximaal $0,18 \mathrm{~m}^{2}$ per varken(BWL 2004.05.V4) ${ }^{5}$

D 3.2.7.2.2 emitterend mestoppervlak groter dan $0,18 \mathrm{~m}^{2}$, maar kleiner dan $0,27 \mathrm{~m}^{2}$ per varken( $B W L$ 2010.10.v3) 5 
2007.03.V6; BWL 2008.01.V4; BWL 2008.02.V4; BWL 2008.03.V4; BWL 2008.04.V4; BWL 2008.05.V4; BWL 2008.12.V4; BWL 2009.13. V4; BWL 2009.20.V3; BWL 2009.21.V2; BWL 2010.27.V4; BWL 2010.28.V4; BWL 2011.11.V3; BWL 2011.12.V3; BWL 2013.02.V2; BWL 2015.04.V2) ${ }^{3}$

D 3.2.9 chemisch luchtwassysteem 70\% emissiereductie (BWL 2004.02.V4; BWL 2005.01.V6; BWL 2006.04.V3; BWL 2006.05.V4; BWL 2008.06.V5; BWL 2008.07.V3; BWL 2009.01.V4; BWL 2010.25.V2; BWL 2011.14.V3; BWL 2014.01.V2), ${ }^{3}$

D 3.2.10 bollevloerhok met betonnen morsrooster en metalen driekantrooster

D 3.2.10.1 emitterend mestoppervlak maximaal 0,22 $\mathrm{m}^{2}$ per varken(BWL 2001.27.V3)

\begin{tabular}{ll} 
D 3.2.10.2 emitterend mestoppervlak maximaal 0,33 $\mathrm{m}^{2}$ per varken(BWL 2001.27.V3) ${ }^{5}$ & 1,4 \\
\hline
\end{tabular}

$\begin{array}{ll}\text { D 3.2.11 hok met gescheiden mestkanalen (BWL 2001.03.V1) })^{5} & 1,7\end{array}$

$\begin{array}{lll}D & \text { spoelgotensysteem met metalen driekantroosters(Groen Label BB 98.10.064) } & 1,2 \\ \end{array}$

\begin{tabular}{lll} 
D 3.2.13 spoelgotensysteem met roosters(Groen Label BB 98.10.065; BB 98.10.065/A 99.11.079V1) ${ }^{5}$ & 1,7 \\
\hline
\end{tabular}

D 3.2.14 chemisch luchtwassysteem 95\% emissiereductie(BWL 2007.05.V5; BWL 2008.08.V4; BWL $\quad 0,15$ 2008.09.V4; BWL 2010.26.V2) ${ }^{3,5}$

D 3.2.15 luchtwassystemen anders dan biologisch of chemisch

D 3.2.15.1 gecombineerd luchtwassysteem 85\% emissiereductie met chemische wasser (lamellenfilter) $\quad 0,45$ en waterwasser(BWL 2006.14.V5) ${ }^{3,5}$

D 3.2.15.2 gecombineerd luchtwassysteem 70\% emissiereductie met waterwasser, chemische wasser en $\quad 0,9$ biofilter(BWL 2006.15.V6) $)^{3,5}$

D 3.2.15.3 gecombineerd luchtwassysteem $85 \%$ emissiereductie met waterwasser, chemische wasser en $\quad 0,45$ biofilter(BWL 2007.01.V6) $)^{3,5}$

D 3.2.15.4 gecombineerd luchtwassysteem $85 \%$ emissiereductie met watergordijn en biologische 0,45 wasser(BWL 2007.02.V4; BWL 2009.12.V2; BWL 2010.02.V4) ${ }^{3,5}$

D 3.2.15.5 gecombineerd luchtwassysteem 85\% emissiereductie met waterwasser, biologische wasser $\quad 0,45$ en geurverwijderingssectie(BWL 2011.07.V3) ${ }^{3,5}$

D 3.2.15.6 gecombineerd luchtwassysteem $90 \%$ emissiereductie met een biologische en een chemische $\quad 0,3$ wasser en een biofilter(BWL 2011.08.V3) ${ }^{3,5}$

D 3.2.16 gescheiden afvoer van mest en urine door middel van een $V$-vormige mestband in het $\quad 1,1$ mestkanaal met metalen driekant roosters op het mestkanaal(BWL 2008.11.V1) ${ }^{5}$

D 3.2.17 biologisch luchtwassysteem $85 \%$ emissiereductie(BWL 2012.07.V3) ${ }^{3}$

D 3.2.18 chemisch luchtwassysteem 90\% emissiereductie(BWL 2013.08.V1) ${ }^{3} \quad 0,3$

D 3.3 scharrel vleesvarkens

D 3.3.1 beddenstal met maximaal $0,14 \mathrm{~m}^{2}$ emitterend mestoppervlak per dier tot $50 \mathrm{~kg}$ levend gewicht en met maximaal $0,29 \mathrm{~m}^{2}$ emitterend mestoppervlak per dier vanaf $50 \mathrm{~kg}$ levend gewicht $\left(B W L\right.$ 2001.30) ${ }^{5}$

$\begin{array}{lll}\text { D 3.3.2 overige huisvestingssystemen scharrel vleesvarkens }{ }^{5} & 3,0\end{array}$

$\begin{array}{ll}\text { D } 3.100 \quad \text { overige huisvestingssystemen } & 3,0\end{array}$

\begin{tabular}{|c|c|c|}
\hline E 5 & diercategorie vleeskuikens & \\
\hline \multirow[t]{2}{*}{ E 5.1} & zwevende vloer met strooiseldroging(Groen Label BB 93.03.002; BB 93.03.002/A & \multirow[t]{2}{*}{0,005} \\
\hline & 94.04.017V1; BB 93.03.002/B 96.04.034; BB 93.03.002/C 96.10.048) & \\
\hline E 5.2 & $\begin{array}{l}\text { geperforeerde vloer met strooiseldroging(Groen Label BB 94.04.016; BB 94.04.016/A } \\
\text { 96.10.047) }\end{array}$ & 0,014 \\
\hline E 5.3 & etagesysteem met volledige roostervloer en mestbandbeluchting(Groen Label BB 97.07.057) & 0,005 \\
\hline E 5.4 & $\begin{array}{l}\text { chemisch luchtwassysteem } 90 \% \text { emissiereductie(BWL 2008.08.V4; BWL 2007.05.V5; BWL } \\
\text { 2013.08.V1) }\end{array}$ & 0,008 \\
\hline E 5.5 & grondhuisvesting met vloerverwarming en vloerkoeling(BWL 2001.11.V2) ${ }^{11}$ & 0,045 \\
\hline E 5.6 & stal met mixluchtventilatie(BWL 2005.10.V4) ${ }^{11}$ & 0,037 \\
\hline E 5.7 & $\begin{array}{l}\text { biologisch luchtwassysteem 70\% emissiereductie (BWL 2006.02.V4; BWL 2007.03.V6; BWL } \\
\text { 2009.13.V4; BWL 2010.27.V4; BWL 2010.28.V4; BWL 2011.11.V3; BWL 2013.02.V2; BWL } \\
\text { 2015.04.V2) }\end{array}$ & 0,024 \\
\hline E 5.8 & etagesysteem met mestband en strooiseldroging $(B W L 2006.13)^{6}$ & 0,020 \\
\hline E 5.9 & uitbroeden eieren en opfokken vleeskuikens met aparte vervolghuisvesting & \\
\hline E 5.9.1 & uitbroeden eieren en opfokken vleeskuikens in etages met vervolghuisvesting & \\
\hline
\end{tabular}




\begin{tabular}{|c|c|c|}
\hline RAV-code & Huisvestingssysteem per categorie & $\begin{array}{r}\text { Emissie in } \\
\mathbf{k g ~ N H} \text { per } \\
\text { dierplaats } \\
\text { per jaar 1) }\end{array}$ \\
\hline E 5.9.1.1 & $\begin{array}{l}\text { uitbroeden eieren en opfokken vleeskuikens tot } 13 \text { dagen in stal met etages en } \\
\text { vervolghuisvesting }\end{array}$ & \\
\hline E 5.9.1.1.1 & $\begin{array}{l}\text { uitbroeden eieren en opfokken vleeskuikens tot } 13 \text { dagen in stal met etages en } \\
\text { vervolghuisvesting in E } 5.5 \text { (grondhuisvesting met vloerverwarming en vloerkoeling)(BWL } \\
2009.02)^{12}\end{array}$ & 0,040 \\
\hline E 5.9.1.1.2 & $\begin{array}{l}\text { uitbroeden eieren en opfokken vleeskuikens tot } 13 \text { dagen in stal met etages en } \\
\text { vervolghuisvesting in E } 5.6 \text { (stal met mixluchtventilatie)(BWL 2009.03) }{ }^{12}\end{array}$ & 0,033 \\
\hline E 5.9.1.1.3 & $\begin{array}{l}\text { uitbroeden eieren en opfokken vleeskuikens tot } 13 \text { dagen in stal met etages en } \\
\text { vervolghuisvesting in E } 5.8 \text { (etagesysteem met mestband en strooiseldroging)(BWL 2009.04) } \\
6,12\end{array}$ & 0,018 \\
\hline E 5.9.1.1.4 & $\begin{array}{l}\text { uitbroeden eieren en opfokken vleeskuikens tot } 13 \text { dagen in stal met etages en } \\
\text { vervolghuisvesting in E } 5.10 \text { (stal met verwarmingssysteem met warmteheaters en } \\
\text { ventilatoren)(BWL 2009.15) }\end{array}$ & 0,031 \\
\hline E 5.9.1.1.100 & $\begin{array}{l}\text { uitbroeden eieren en opfokken vleeskuikens tot } 13 \text { dagen in stal met etages en } \\
\text { vervolghuisvesting in E } 5.100 \text { (overige huisvestingsystemen)(BWL 2009.08) }{ }^{12}\end{array}$ & 0,070 \\
\hline E 5.9.1.2 & $\begin{array}{l}\text { uitbroeden eieren en opfokken vleeskuikens tot } 19 \text { dagen in stal met etages en } \\
\text { vervolghuisvesting }\end{array}$ & \\
\hline E 5.9.1.2.1 & $\begin{array}{l}\text { uitbroeden eieren en opfokken vleeskuikens tot } 19 \text { dagen in stal met etages en } \\
\text { vervolghuisvesting in E } 5.5 \text { (grondhuisvesting met vloerverwarming en vloerkoeling)(BWL } \\
2009.05)^{13}\end{array}$ & 0,038 \\
\hline E 5.9.1.2.2 & $\begin{array}{l}\text { uitbroeden eieren en opfokken vleeskuikens tot } 19 \text { dagen in stal met etages en } \\
\text { vervolghuisvesting in E } 5.6 \text { (stal met mixluchtventilatie)(BWL 2009.06) }{ }^{13}\end{array}$ & 0,033 \\
\hline E 5.9.1.2.3 & $\begin{array}{l}\text { uitbroeden eieren en opfokken vleeskuikens tot } 19 \text { dagen in stal met etages en } \\
\text { vervolghuisvesting in E } 5.8 \text { (etagesysteem met mestband en strooiseldroging)(BWL 2009.07) } \\
6,13\end{array}$ & 0,015 \\
\hline E 5.9.1.2.4 & $\begin{array}{l}\text { uitbroeden eieren en opfokken vleeskuikens tot } 19 \text { dagen in stal met etages en } \\
\text { vervolghuisvesting in E } 5.10 \text { (stal met verwarmingssysteem met warmteheaters en } \\
\text { ventilatoren)(BWL 2009.16) }\end{array}$ & 0,030 \\
\hline E 5.9.1.2.100 & $\begin{array}{l}\text { uitbroeden eieren en opfokken vleeskuikens tot } 19 \text { dagen in stal met etages en } \\
\text { vervolghuisvesting in E } 5.100 \text { (overige huisvestingsystemen)(BWL 2009.09) }{ }^{13}\end{array}$ & 0,060 \\
\hline E 5.10 & stal met verwarmingssysteem met warmteheaters en ventilatoren(BWL 2009.14.V5) ${ }^{11}$ & 0,035 \\
\hline E 5.11 & $\begin{array}{l}\text { stal met luchtmengsysteem voor droging strooisellaag in combinatie met een } \\
\text { warmtewisselaar(BWL 2010.13.V5) }{ }^{11}\end{array}$ & 0,021 \\
\hline E 5.12 & biofilter $70 \%$ emissiereductie $\left(B W L\right.$ 2011.03.V1) ${ }^{3}$ & 0,024 \\
\hline E 5.13 & $\begin{array}{l}\text { chemisch luchtwassysteem 70\% emissiereductie (BWL 2005.01.V6; BWL 2008.06.V5; BWL } \\
\text { 2014.01.V2) }\end{array}$ & 0,024 \\
\hline E 5.14 & $\begin{array}{l}\text { stal met warmteheaters met luchtmengsysteem voor droging strooisellaag(BWL 2011.13.V4) } \\
11\end{array}$ & 0,035 \\
\hline E 5.15 & Stal met buizenverwarming (BWL 2017.01) & 0,012 \\
\hline E 5.100 & overige huisvestingssystemen & 0,080 \\
\hline
\end{tabular}

1) For dairy cattle with more than 720 grazing hours the ammonia emission from stables is $5 \%$ lower. 


\section{Appendix 4a An overview of the rules regarding the emission of ammonia in Denmark before 1 August 2017}

\begin{tabular}{|c|c|c|c|}
\hline \multicolumn{4}{|c|}{ Rules until August 1st 2017} \\
\hline $\begin{array}{l}\text { When permitting livestock } \\
\text { installations }\end{array}$ & $\begin{array}{c}\S 10 \\
\text { Farms of } 15-75 \text { LSU } \\
\text { (Fur farms of 3-25 LSU) }\end{array}$ & $\begin{array}{c}\text { \$11 } \\
\text { Farms of 75-250 LSU } \\
\text { (Fur farms } 25-250 \text { LSU) }\end{array}$ & $\begin{array}{c}\S 12 \\
\text { Farms of more than } 250 \\
\text { LSU }\end{array}$ \\
\hline $\begin{array}{l}\text { Technology / emission } \\
\text { limits }\end{array}$ & Reference & $\begin{array}{l}\text { BAT and } 30 \% \text { emission } \\
\text { reduction compared to } \\
2005 / 2006 \text { level }\end{array}$ & $\begin{array}{l}\text { BAT and } 30 \% \text { emission } \\
\text { reduction compared to } \\
2005 / 2006 \text { level }\end{array}$ \\
\hline $\begin{array}{l}\text { Maximum deposition on } \\
\text { Category } 1 \text { habitats }\end{array}$ & No maximum & $\begin{array}{l}0.2-0.7 \mathrm{~kg} \mathrm{~N} / \mathrm{ha} / \mathrm{year} \\
\text { depending on number of } \\
\text { farms in proximity }\end{array}$ & $\begin{array}{l}0.2-0.7 \mathrm{~kg} \mathrm{~N} / \mathrm{ha} / \mathrm{year} \\
\text { depending on number of } \\
\text { farms in proximity }\end{array}$ \\
\hline $\begin{array}{l}\text { Maximum deposition on } \\
\text { Category } 2 \text { habitats }\end{array}$ & No maximum & $1.0 \mathrm{~kg} \mathrm{~N} / \mathrm{ha} /$ year & $1.0 \mathrm{~kg} \mathrm{~N} / \mathrm{ha} /$ year \\
\hline $\begin{array}{l}\text { Maximum deposition on } \\
\text { Category } 3 \text { habitats }\end{array}$ & No maximum & $\begin{array}{c}\text { Individual assessment above } \\
1.0 \mathrm{~kg} \mathrm{~N} / \mathrm{ha} / \text { year }\end{array}$ & $\begin{array}{c}\text { Individual assessment above } \\
1.0 \mathrm{~kg} \mathrm{~N} / \mathrm{ha} / \text { year }\end{array}$ \\
\hline $\begin{array}{l}\text { Maximum deposition on } \\
\text { other nutrient sensitive } \\
\text { habitats, e.g. ponds and } \\
\text { meadows }\end{array}$ & Individual assessment & Individual assessment & Individual assessment \\
\hline $\begin{array}{l}\text { Impact on Annex IV } \\
\text { species and habitats }\end{array}$ & Individual assessment & Individual assessment & Individual assessment \\
\hline
\end{tabular}




\section{Appendix 4b An overview of the rules from 1 August 2017 onwards}

\begin{tabular}{|c|c|c|}
\hline \multicolumn{3}{|c|}{ Rules from August 12017} \\
\hline $\begin{array}{l}\text { When permitting livestock } \\
\text { installations }\end{array}$ & Above $100 \mathrm{~m}^{2}$ production area & $\begin{array}{l}\text { IED-thresholds or } \\
\text { above } 3.500 \mathrm{~kg} \mathrm{NH}-\mathrm{N} / \text { year }\end{array}$ \\
\hline $\begin{array}{l}\text { Technology / emission } \\
\text { limits }\end{array}$ & BAT if emission exceeds $750 \mathrm{~kg} \mathrm{NH}_{3}-\mathrm{N} /$ year & BAT \\
\hline $\begin{array}{l}\text { Maximum deposition on } \\
\text { Category } 1 \text { habitats }\end{array}$ & $\begin{array}{l}0.2-0.7 \mathrm{~kg} \mathrm{~N} / \mathrm{ha} / \text { year depending on number } \\
\text { of farms in proximity }\end{array}$ & $\begin{array}{l}0.2-0.7 \mathrm{~kg} \mathrm{~N} / \mathrm{ha} / \text { year depending on number } \\
\text { of farms in proximity }\end{array}$ \\
\hline $\begin{array}{l}\text { Maximum deposition on } \\
\text { Category } 2 \text { habitats }\end{array}$ & $1.0 \mathrm{~kg} \mathrm{~N} / \mathrm{ha} /$ year & $1.0 \mathrm{~kg} \mathrm{~N} / \mathrm{ha} /$ year \\
\hline $\begin{array}{l}\text { Maximum deposition on } \\
\text { Category } 3 \text { habitats }\end{array}$ & $\begin{array}{c}\text { Individual assessment above } 1.0 \mathrm{~kg} \\
\mathrm{~N} / \mathrm{ha} / \text { year }\end{array}$ & $\begin{array}{l}\text { Individual assessment above } 1.0 \mathrm{~kg} \\
\mathrm{~N} / \mathrm{ha} / \text { year }\end{array}$ \\
\hline $\begin{array}{l}\text { Maximum deposition on } \\
\text { other sensitive habitats, } \\
\text { e.g. ponds and meadows }\end{array}$ & Individual assessment & Individual assessment \\
\hline $\begin{array}{l}\text { Impact on Annex IV } \\
\text { species and habitats }\end{array}$ & Individual assessment & Individual assessment \\
\hline
\end{tabular}


Wageningen Economic Research P.O. Box 29703

2502 LS The Hague

The Netherlands

$\mathrm{T}+31(0) 703358330$

E communications.ssg@wur.nl

www.wur.eu/economic-research

Wageningen Economic Research REPORT

2018-009
The mission of Wageningen University \& Research is "To explore the potential of nature to improve the quality of life". Under the banner Wageningen University \& Research, Wageningen University and the specialised research institutes of the Wageningen Research Foundation have joined forces in contributing to finding solutions to important questions in the domain of healthy food and living environment. With its roughly 30 branches, 5,000 employees and 10,000 students, Wageningen University \& Research is one of the leading organisations in its domain. The unique Wageningen approach lies in its integrated approach to issues and the collaboration between different disciplines. 



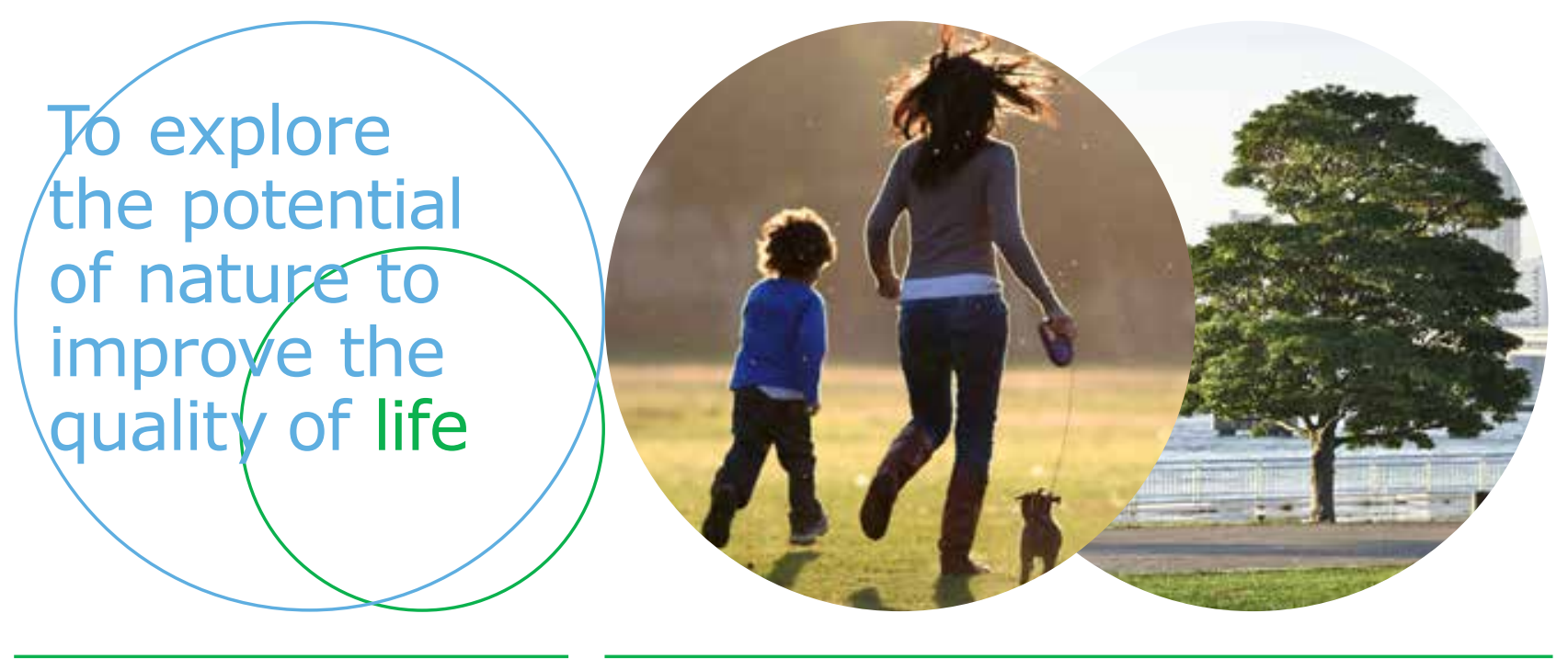

Wageningen Economic Research Postbus 29703

2502 LS Den Haag

E communications.ssg@wur.nl

T +31 (0)7033583 30

www.wur.nl/economic-research

Report 2018-009

ISBN 978-94-6343-766-0
De missie van Wageningen University \& Research is 'To explore the potential of nature to improve the quality of life'. Binnen Wageningen University \& Research bundelen Wageningen University en gespecialiseerde onderzoeksinstituten van Stichting Wageningen Research hun krachten om bij te dragen aan de oplossing van belangrijke vragen in het domein van gezonde voeding en leefomgeving. Met ongeveer 30 vestigingen, 5.000 medewerkers en 10.000 studenten behoort Wageningen University \& Research wereldwijd tot de aansprekende kennisinstellingen binnen haar domein. De integrale benadering van de vraagstukken en de samenwerking tussen verschillende disciplines vormen het hart van de unieke Wageningen aanpak. 